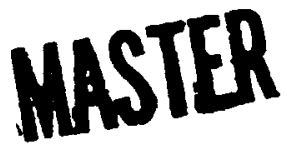

Precliction of Temperature Increases in a Salt Repository Expected from the Siorage of Spent Fuel or High-Level Y:aste

\author{
G. H. Llewellyn
}


Contract No. W-7405-eng-26

okN Engineering

PRE!ICTION OF TEMPERATURE INCREASES IN A

SALT REPOSITORY EXPECTED FROM THE

STORAGE OF SPENT FLEL OR HIGH-LEVEL WASTE

G. H. Llewellyn

Date Published: April 1978

OAK RIDGE NATIONAL LABORATORY

Oa: Ridge, Tennessee 37830

operated by

UNTON CARBIDE CORPORATION

for the

DEPARTMENT OF ENERGY

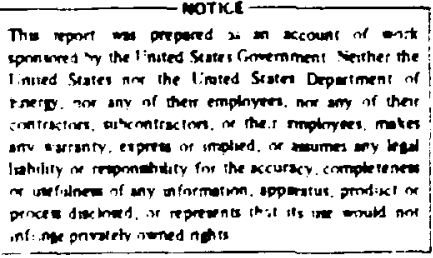

ment of

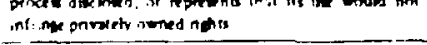


TABLE OF CCNTENTS

Page

LIST OF IICURES . . . . . . . . . . . . . . . . . . . v

LIST OF TABLES . . . . . . . . . . . . . . . . . IX

FOREWORD ............................ . $x 1$

ACKNOWLEDGMENTS . . . . . . . . . . . . . . . . . . . . xi11

ABSTRACT . . . . . . . . . . . . . . . . . . . . $\mathrm{xV}$

1. SUMMARY ........................ 1

2. INTRODUCTIOI . . . . . . . . . . . . . . . . . . 3

2.1 Background and Design Limitacions............ 3

2.2 Objectives of the Analysis .............. 7

2.3 Factors Involved in Formulating a kepository

Model in Salt . . . . . . . . . . . . . . 7

2.4 Definition of Temperature Terms.......... 8

3. SOLLTION TECHNIQUE .................... . . 9

4. HEAT SOURCES AND DECAY RATES . . . . . . . . . . . . . . . 11

4.1 Heat Sources Used in the Models for the

Preliminary Comparisons................ 11

4.2 Heat Sources Used in the Far-Field Models for the

Detalled Comparisons ................ 11

4.3 Heat Sources User for the Unit-Cell Models in

the Deta:lec Comparisons .............. 12

4.4 Decay Rates for SF and HLW . . . . . . . . . . 12

4.5 Normal $\{z$ 2d Decay Rates ................ 15

4.6 Ratio (SF/HLW) Stored Energy as a Function of Time . . . 16

5. BOUNDARY CONUITIONS . . . . . . . . . . . . . . 18

c. PHYSICAL PROPERTIES AND INITIAL CONDITIONS . . . . . . . . 19

6.1 Physical Properties............... 19

6.2 Stratigraphy .................. 19

6.3 Intifal Temperature Distribution ......... 20

7. PRELIMINARY COMPARISONS OF SF AND HLW AT $150 \mathrm{~kW} / A C R E$ AND

$3.5 \mathrm{~kW} /$ CANISTER . . . . . . . . . . . . . . . 23

7. 1 Two-Dimensicnal Far-Field Model Used in the

Preliminary Comparisonc - Cases A and B........ . 25

7.2 Two-Dimensional Unit-Cel1 Model Used in

Preliminary Comparisons - Cases C and D . . . . . . . 25

7. 3 Peak Temperature Increases Calculated for the

Preliminary Comparisons . . . . . . . . . . . 26 
BLANK PAGE 
8. HEAT TRANSFER MODELS FOR DETAILED COMPARISONS OF SF

STORED AT $60 \mathrm{~kW} / A C R E$ AND $0.55 \mathrm{kh} /$ CANISTER AND HLW

STORED AT $150 \mathrm{~kW} /$ ACRE AND $2.1 \mathrm{~kW} /$ CANISTER . . . . . . . . . . 29

8.1 One-Dimensional Models (Cases 0 and $O r$ ) and Results....................... 31

8.2 Two-Dimensicnal Far-Field Model (Cases 1 and 2) and Numerical Results ... . . . . . . . . . . 32

8.3 Two-ilimensional Unit-Cell Modeis (Cases 3 and 4) and Numerical Results.............. . . 38

8.4 Three-Dimensional Models (Cases 5 ana 6) and Numerical Results... . . . . . . . . . . 40

8.5 Multiple Row Far-Field Model of a High-Level Waste Repository ( iase 7) and Numerical Results....... 50

9. COMPARISON OF RESULTS FROM HIGH-LEVEL WASTE MGDELS . . . . . 56

9.1 Temperature Differences as Functions of Time . . . . . 56

9.2 Temperature Increases as Functions of Depth

Below the Surface of the Earth . . . . . . . . . 60

10. RESULTS AND CONCLUSIONS . . . . . . . . . . . . . 64

REFERENCES . . . . . . . . . . . . . . . . . 66 


\section{LIST OF FICLRES}

Figure

Page

2.1 Artist's conception of a radioactive waste repository . . 5

2.2 Room spacing concept ................. 6

4.1 Canister emplacement conceft for detailed unit-cell

model ................... . . 13

4.2 Power production rate for PWR and BWR spent fuel

assemblies and $6.28-\mathrm{ft}^{3}$ canisters of $\mathrm{HLH}$ as functions

of tine for periods to 100,000 years . . . . . . . . . 14

4.3 Normalized heat generalized for SF and HLW as

functions of time . . . . . . . . . . . . . . 15

4.4 Ratio (SF/HLW) of total energy released as a fuaction

of time after reprocessing or removal from reactor . . . . 17

6.1 Theitual conductivity of halite and domed salt as

functions of temperature . . . . . . . . . . . 20

6.2 Geothermal gradients . . . . . . . . . . . . 21

T.1 Midplane temperature increases in salt as functions

of burial time for cases A, B, C, and D . . . . . . 27

7.2 Temperature increases at a depth of $2000 \mathrm{ft}$ at the edg $s$ of a repository containing ST or HLW as a function

of burfal time.................. . . . 28

8.1 Peak temperature increases in one-dimensional salt

models as functions of depth for SF stored at

$60 \mathrm{kN} / \mathrm{acre}$ and $\mathrm{HLW}$ stored at $150 \mathrm{~kW} / \mathrm{acre} . . . . . . .33$

2 Two-dimensional homogenized far-field heat transfer

mode1 of a 2217-acre SF repository . . . . . . . . . . . 34

8.3 Two-dimeasional homogenized far-field heat transfer

model of an 883-acre HLW repository . . . . . . . . . . . . 34

8.4 Centerline temperature increase in a two-dimensional

far-field model at various times as functi, ns of

depth resulting from the storage of $\mathrm{SF}$ at $60 \mathrm{~kW} / \mathrm{acre} . . .36$

8.5 Centerline temperature increase il: salt in a two-

dimensional far-field model at various times as

function of depth resulting from the storage of HLW

at $150 \mathrm{~kW} /$ acre . . . . . . . . . . . . . 
8.6 Midplane temperature increases in salt at various tines as functions of radial distances from the centerline in a repository loaded wth SF at $60 \mathrm{~kW} /$ acre . . . . . . . . . . . . . . . . 38

8.7 Midplane temperaz:ire increases in saj.t at various times as functions of radial distances from the centerline in a repository loaded with $\mathrm{HLW}$ at $150 \mathrm{kh} /$ acre .................. . . . 39

8.8 Centerline temperature fucrease in salt in a twodimenstoral far-field model at various depths as functions of time resulting frow the storage of

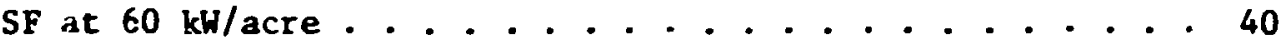

8.9 Centerline temperature increases in salt in a wodimensional far-fleld model at varfous depths as functions of time resulting from the storage of HLW at $150 \mathrm{~kW} /$ acre . . . . . . . . . . . . . . . 41

8.10 Midplane temperature increases at various radial locations as functions of time in a repcsitory

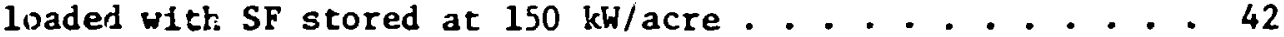

8.11 Midplane temperature increases at various radial locations as functions of time in a reposicory loaded with HLW stored at $60 \mathrm{~kW} /$ acre . . . . . . . . 43 43

8.12 Two-dimensicnal unit-cell model fo: storage of a canister containing a spent fuel assembly . . . . . . . . 44

8.13 Two-dimenstoral unit-cell model for storage of a cantster of HLI

8.14 Comparison of maximum temperature increases as functions of rime in the two-dimensional unit-cell models for SF stored at $60 \mathrm{~kW} / \mathrm{acre}$ and HLW stored at $150 \mathrm{~kW} /$ acre ............... . . 45

8.15 Three-dimensional unit-cell model for a PWR spent fuel assembly or in.W canister . . . . . . . . . . . . . 46

8.16 Comparison of maximum temperature increases in salt as functions of time in the three-dimensional unit-cell models for SF stored at $60 \mathrm{~kW} / \mathrm{acre}$ and HLW stored at $150 \mathrm{kH} /$ acre . . . . . . . . . . . . . . 47 
8.1? Comparison of maximum temperature on the fioor of the storage room as functions of time due to SF stored at $60 \mathrm{~kW} /$ acre and $\mathrm{HLW}$ st: red at $150 \mathrm{~kW} /$ acre . . . . . . . . 48

8.18 Contours for temperature Increases in the $X 2$ plane 25 years after burial in the three-dimensional unit-cell model for SF stored at $60 \mathrm{kH} /$ acre . . . . . . . 49

8.19 Contours for temperature increases in the norizontal midplane 25 years after burtal in the threeiimensional untt-cell model for SF stored at $60 \mathrm{kH} /$ acre . . . . . . . . . . . . . . . . 50

8.20 Contiurs for temperature increases in the $X Z$ plane 5 years after burlal in the three-dimensional unitcell model for tLW stored at $150 \mathrm{~kW} /$ acre . . . . . . . . 51

8.21 Contors for temperature increases in the horizontal midplane 5 years after burial in the three-dimensional unit-cell model for HLW stored at $150 \mathrm{kH} /$ acre . . . . . . 52

8.22 Section through multiple row model showing repository from the center to the edge . . . . . . . . 53

8.23 Temperature increases at various depths in the salt repository as a function of horizontal position .... . . 54

9.1 Comparison of temperature increases from vartous models of an HLW repository as functions of time . . . . . 57

9.2 Comparison of midplane temperature increases on outer edge of repository obtained from two-dimensional far-field models storing $\mathrm{HLW}$ at $150 \mathrm{~kW} / \mathrm{acre}$ as functions of time ..................... . . 60

9.3 Midplane temperacure increases in fax-field models produced by SF and HLW as a function of areal heat load .... . . . . . . . . . . . . . . . . 61

9.4 Comparison of peak temperature increasez obtained from varlous far-field models for storing HLW as functions of depth below the surface of the earth . . . . 62

9.5 Comparison of peak temperature increases from twoand three-dimensional unit-cell models as functions of depth below the surface of the earth, Incurred in the stcrage of $\mathrm{HLW}$ at $150 \mathrm{~kW} / \mathrm{acre} . . . . . . . . . .63$ 


\section{LIST OF TABLES}

Tat le

Page

2.1 Radloactive waste types considerea in repository design ........................... 4

7.1 Two-dimensional $R, Z$ conputer models for prelininary comparisons - cases A through D . . . . . . . . . . 24

8.1 Computer mudels for detalled comparisons - cases 0

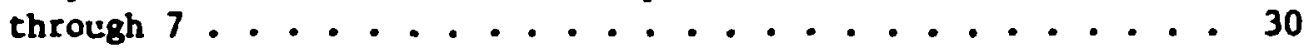


This report was prepared by the Engineering Division of Union Carbite Corporation, Nuclear Division, in cooperation with the office of Waste Isolation and is part of the National Waste Terminal Storage Program. The principal objective of this program is to establish facilithes in various derep geologic formations at several locations in the United States wilh will safely dispose of commercial radioactive waste. This report considers the waste to be either unreprocessed spent fuel or high-level waste. As part of the Thermal Analysis Studies of the Office of Waste Isulation, this report compares the thermal responses to the burial of spent fuel and high-level waste in hypothetical repositories in salt. 


\section{ACKNOULEDGMENTS}

The author wishes to acknowledge the help of $\mathrm{W}$. A. Burnett of OWT and M. Siman-Tov of UCC-ND Engineering Division in the organization and review of the report and W. D. Turner and D. C. Elrod, of UCC-ND Computer Sciences Division, for their assistance in processing and verification of the computer models. Appreciation is extended to T. Whitus, J. M. Hackworth, J. R. McIntosh, and R. D. Harrell for the figures used in the report. This report was sponsored by the Office of Waste Isolation, UCC-LD, OAk RIdge, Tennessee. 
Comparisons in temperature increases ircurred from hypothetical storage of $133 \mathrm{MW}$ of 10-year-old spent fuel (SF) or high-level waste (HLW) In underground salt formations have been made using the HEATING5 computer code. The comparisons are based on far-field homogentzed models that cover areas of 65 and $25 \mathrm{sq} \mathrm{miles}$ for SF and HLW, respectively, and near-field unit-cell models covering respective areas of $610 \mathrm{ft}^{2}$ and $400 \mathrm{ft}^{2}$. P=eliminary comparisons based on heat loals of $150 \mathrm{kH} /$ acre and $3.5 \mathrm{~kW} /$ canister Indicated near-field temferature fncreases about $20 \%$ higher for the storage of the spent fuel than ior the high-level waste. In these comparisons, it was also found that the thermal enirgy deposited in the salt after 500 years Is about twice the energy deposited by the high-level waste.

The thermal load in a reposicory containing 10-year-old spent fuel was thus limlted to $60 \mathrm{~kW} / a c r e$ to obtaln comparable far-field thermal effects as obtained in a repository contalning 10-year-old high-level waste lnaded at $150 \mathrm{~kW} /$ acre. Detalled far-fleld and unft-cell comparisons of transient temperature increases have been made based on these loadings. Untt-cell comparisons were made between a canister containing high-level waste with an initial heat production rate of $2.1 \mathrm{~kW}$ and a canister containing a PWR spent fuel assembly producing $0.55 \mathrm{~kW}$.

Using a three-dimensional unit-cell model, a maximum salt temperature increase of $260^{\circ} \mathrm{F}$ was calculated for the high-level waste prior to backfilling ( 5 years after burial), whereas a maxivum temperature increase of $110^{\circ} \mathrm{F}$ was calculated for the spent fuel prior to backfilling (25 years after burial).

Comparisons were also made between varlous configurational models for the high-level waste showing the applicability of each model. 


\section{SUMMARY}

Preliminary compariscns have been made between the thermal responses of high-level waste (HLW) and spent fuel assemblies (SF), each stored in salt repositories at an areal heat load of $150 \mathrm{~kW} / a c r e$ and an initial canister heat production rate of $3.5 \mathrm{~kW}$. The restuts of these stidies, based on unit-cell models, indicate a maximlim peak temperature increase of $337^{\circ} \mathrm{F}$ in the salt for the SF storage - about $12 \%$ higher than the peak temperature increase predicted for the HJ.W. The temperature increases based on far-field models were found to be practically uniforn throughout most of the repository. The SF repository temperature increase peaked at $253^{\circ} \mathrm{F}$, which is about $18 \%$ higher than the increase calculated for the HLW.

A thermoelastic analysis ${ }^{1}$ based on far-field models showed that SF stored at $60 \mathrm{~kW} /$ acre produces an upheaval of about $54 \mathrm{in}$. after 1000 years, which is comparable to the upheaval calculated for HLW loaded at $150 \mathrm{~kW} / \mathrm{acre}$. Therefore, additional analyses were performed to compare temperature distributions resulting from the storage of 10-year-old SF at an areal heat load of $60 \mathrm{~kW} /$ acre and $0.55 \mathrm{~kW} /$ canis,ter with those based on the storage of HLW at $150 \mathrm{~kW} /$ acre and $2.1 \mathrm{~kW} /$ canister. In an effort to obtain more accuratc localized temperatures for the actuai canister emplacenent, three-dimensional unit-cell models were created. The analyses made on the three-dimensional unit-cell model containing SF Indicated tha: a maximum temperature increase $(\Delta \mathrm{T})$ of $105^{\circ} \mathrm{F}$ is reached in the salt prior to backfilling (25 years after burial), and a peak maximum $\Delta \mathrm{T}$ of $113^{\circ} \mathrm{F}$ is reachec after 35 years. A peak maximum temperature increase of $105^{\circ} \mathrm{F}$ reached after 60 years was found in the two-dimensional unit-cell modej. The detailed analyses of the HLW storage indicate maximum $\Delta T$ s of $260^{\circ} \mathrm{F}$ for the three-dimensionil unit-cell model after 5 yea:: (which is the proposed backfilling time) with a peak maxim in $\Delta \mathrm{T}$ of $301^{\circ} \mathrm{F}$ reached $s \mathrm{~s}$ about 20 years. A pe $\varepsilon^{\prime}$ maximum $\Delta \mathrm{T}$ of $269^{\circ} \mathrm{F}$ reached in about 25 years was found in the two-dimensional untt-cell model.

The results of all of the unit-cell models were compared with the interim theimal criter1d, ${ }^{2}$ willch allows $1 \%$ of the salt in a unit cell to exceed $482^{\circ} \mathrm{F}$ and $25 \%$ to exceed $392^{\circ} \mathrm{z}$. It was found that these specific thermal criterla are completely satisfied. 


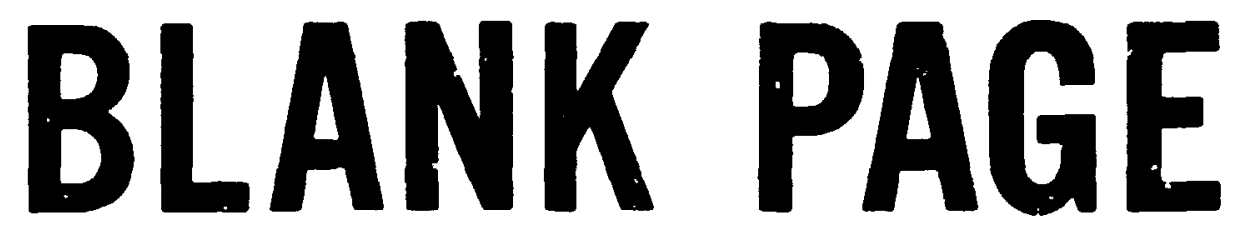


The far-field analysis indicated a fairly uniform temperature throughout the repository midplane; the temperature peaked at about $100^{\circ} \mathrm{F} 60$ years after burial for $\mathrm{SF}$ and at about $225^{\circ} \mathrm{F} 35$ years after burial for HLH.

Although the peak temperature increases were about twice as great for HLW as for SF, the tatal energy delivered to the salt is about the same, resulting in comparable upheavals in both cases. 


\section{INTRGDUCTION}

\subsection{Background and Design Limitations}

The Department of Erergy is currently considering whether or not permanent disposal of radioactive waste can be effectively accomplished by burying it in geclogical formations in a concentrated solid form. Solid radioactive wastes, which are produced in varicus types as shown In Table $2.1,{ }^{3}$ include spent fuel, high-level waste, cladding waste, intermediate-level transuranic waste, and low-level transuranic waste. The maximum heat generation rates were evaluated from available data ard are included in Table 2.1 for comparison. The SF contains only products that result from spent $\mathrm{UO}_{2}$.

Internal heat generation produced by the decay of the radioactive wastes can present major thermal rroblems, and consequentiy the amount that can be stored safely in a specified area of a given medium is Iimited. High-level waste anc spent fuel are the najor causes of concern because tho; have much higher rates of heat production than the other waste forms. Many geological formations are under consideration by the National Waste Terminal Storage (NWTS) program for the establishment of federal repositories. Dome salt, bedded salt, shale, and granite are currently being investigated as potential storage media. The office of waste Isolation (OWI) is currently in the process of formulating conceptual designs for repositories in salt formetions. An artist's conception of a repository in bedded salt is shown in Fig. 2.1. The storage area is located in rooms excavated about one-half mile below the surface of the earth. The waste is stored in canisters placed in holes drilled along the centerline of the room. Figure 2.2 111 ustrates the storage configuration that is used in this report. with 18-ft square rooms and 60-ft pillars. It should be pointed out that other configurations could be used in repository design. Up to $5.3 \mathrm{~kW} /$ canister of HLW has been previously considered and analyzed for storage in a salt repository by Cheverton and Turner. ${ }^{4}$ The HLW can be stored in calcine, 8lass, ceramics, or matrix metal. At present one of the most promising forms of containment material is borosilicate glass, which is rrlatively 
Table 2.1. Radioactive waste types considered in repository design

3pent fuel assemblies (heat generation less than $28,000 \mathrm{~W} / \mathrm{m}^{3}$ )

Pressurized-water reactor (PWR) spent fuel assemblies are assumed to be fueled with $3.3 \%$ enriched $\left({ }^{2} 35 \mathrm{U}\right)$ and subjected ti an exposure of $33,000 \mathrm{MWd} / \mathrm{MTU}$ (1100 days at an average specific power of $30 \mathrm{~mW} / \mathrm{MT}$ ). The mass of uranium per assembly is $0.4614 \mathrm{MT}$.

Bolling-water reactor assemblies are assumed to be subjected to an exposure of $27,500 \mathrm{MWd} / \mathrm{MTU}$ (1328.5 days at an average specific power of $20.7 \mathrm{MW} / \mathrm{MTU})$. The mass of uranium per assembly is $0.1833 \mathrm{MT}$.

High-level waste (heat generation less than $28.000 \mathrm{w} / \mathrm{m}^{3}$ )

Solidified composites of all the llquid waste streams arising from the reprocessing of spent fuels. These wastes contain more than $99.9 \%$ of the nonvolatile fission products, $0.5 \%$ of the uranium and plutonium, and all the other actinides forme 1 by transmutation of the uranium and plutonium in the reactor.

Cladd.1ng waste (heat generation less chan $400 \mathrm{~W} / \mathrm{m}^{3}$ )

Solid fragment of zircaloy ard stainless steel cladding and other structural components of the fuei assemblies that remain after the fuel cores have been dissolved. These fragments are compacted to $70 \%$ of theoretical density. In addition to neutron-induced ridioactivity, the claoding waste contains $0.05 \%$ of the actinides and $0.05 \%$ of the nonvolat 11 e fission products in the spent fuel.

Iatermediate-level transuranic waste (heat generation less than $1.9 \mathrm{~W} / \mathrm{m}^{3}$ )

Those solids or solidified materials (other tha: high-level and cladding wastes) that contain long-lived alpha emitters at concentrations greater than $10 \mathrm{n} / \mathrm{Cl} / \mathrm{g}$, and have typical surface dose rates between 10 and 1000 millirems/hr after packaging due to fission-product contamination.

Low-level transuranic waste (heat generation less than $1.2 \mathrm{~W} / \mathrm{m}^{3}$ )

Those solids or solidified materials that contain plutonium or other long-11ved alpha emitters in knot.n or: suspected concentrations greaser than $10 \mathrm{n} / \mathrm{Ct} / \mathrm{g}$, and yet have sufficiently low exiernal radiation levels after packaging that they can be handled directly 


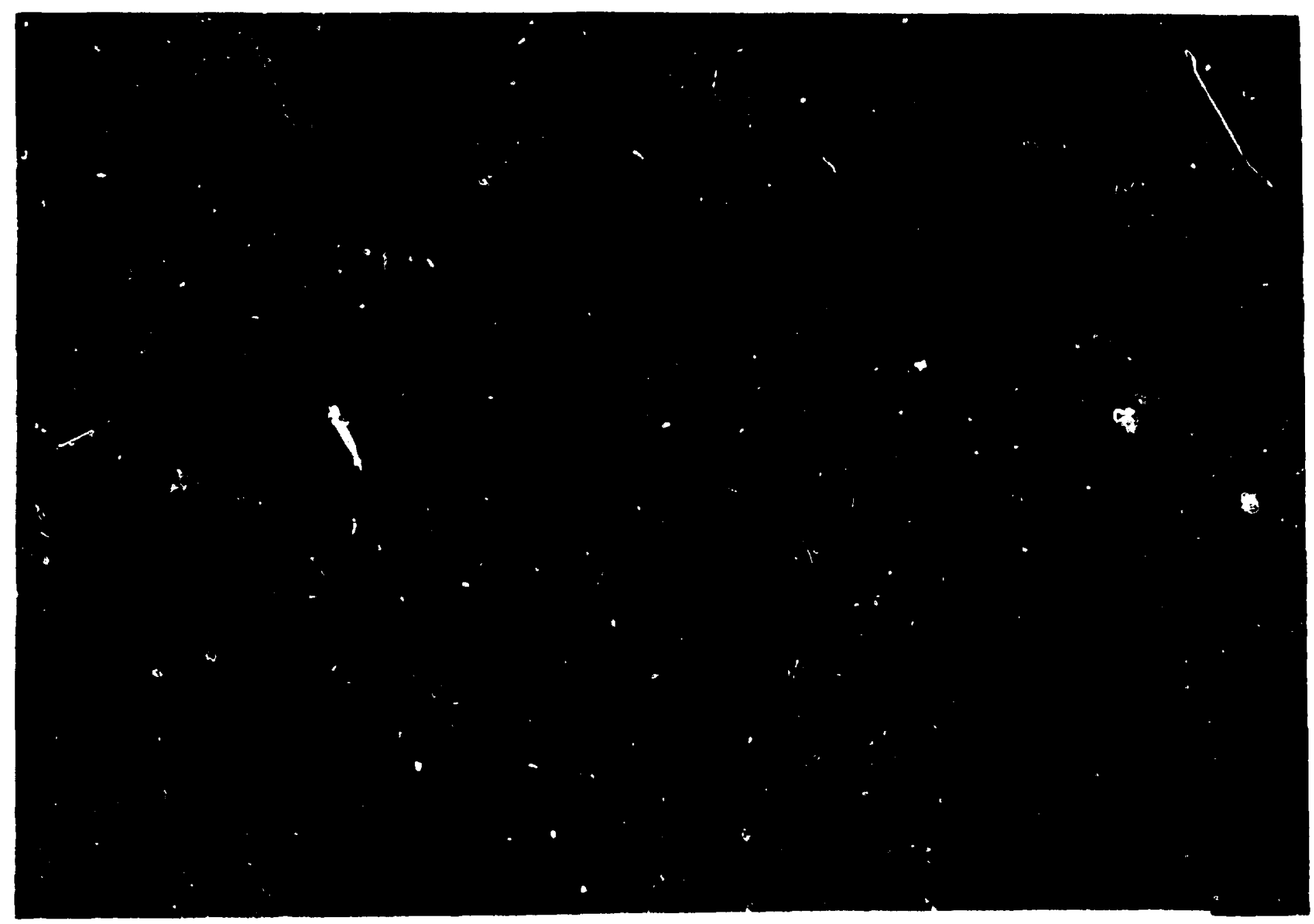

F1g. 2.1. Art1st's conception of a radioactive waste repository. 
ORNL-DWG 78-5466

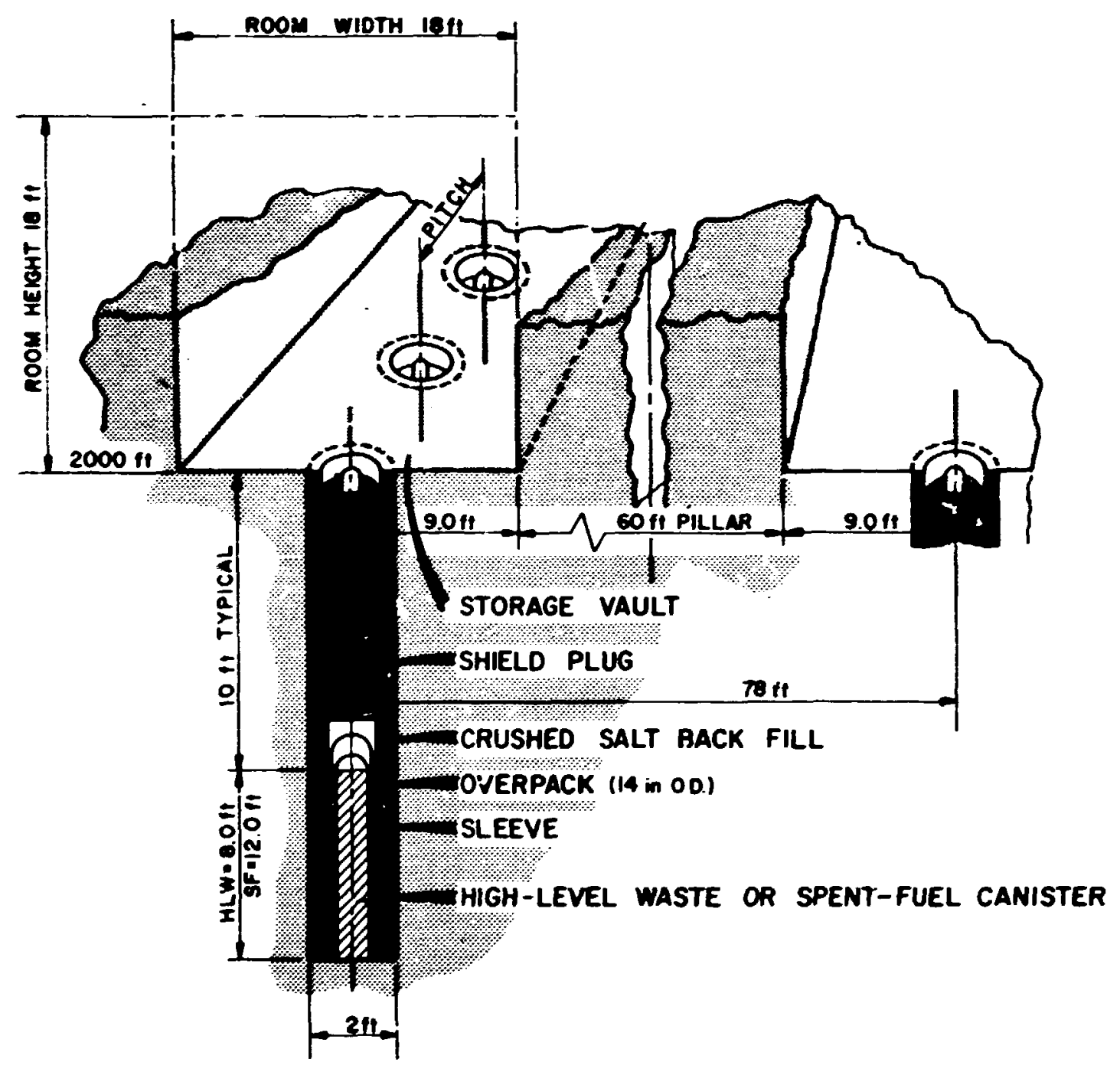

F1g. 2.2. Room spacing concept.

inexpensive and has a high devitrificaticn temperature. The SF cail also be encapsulated in different ways.

The heat produced by the buried waste is dissipated frto the surrounding medium by conduction and is finally transferred from the earth's surface to the atmosphere by natural convection and eventually to deep space by therinal radiation. During this process, a peak temperature is reached in the repository close to the centroid of the heat source. After reaching a maximum value, this peak temperature decreases as a function of time due to the decay of the radioactive materials contained in the canisters. 
Repository design involves detailed heat transfer and rock mechanics studies, including stress and deformation analyses. Temperatures in a salt repository must be controlled because the heat prcduced by the waste causes an increase in creep rate leading to acceierated room closure. After backfilling a room with crushed salt, this consideration is of less importance. It is also necessary to control the temperature to limjt the surficial uplift due to themal expansion, which might compromise the integrity of the repository and/or its environment.

Heat transfer and material evaluations inside of the canister itself are important factors in limiting the heat loads used in the reprository, but these points are being considered in other studies.

\subsection{Objectives of the Analysis}

The purpose of these heat transfer analyses is to provide temperature distributions to be used in structural, safety, and environmental evaluations to confirm the structural integrity in conceptual repository design. The objectives of these analyses are (1) to determine from the transient temperature distributions when and where the peak temperatures occur, (2) to compare the temperature rises obtained from the storage of SF and HILW, and (3) to compare the results obtained from the various modeis employed. Thermal effects in the repository mediur are the main concern, and only emperatures in the medium are considered relevant in this study.

\subsection{Factors Involved in Formulatirg a Repositor; Model in Salt}

In order to attain these objectives, rodels must be created to simulate as accurately and economically as possible the actual situation that will be encountered when large amcunts of heat (up to $133 \mathrm{MW}$ ) in the form of radioactive wastes are buried in a repository. This burial. can be in the terminal mode where the excavated rooms are vackfilled with crushed salt, or it can be in a retrievable mode where the rooms are lefic open to provide the capability of access to or removal of the canisters during the retrlevabilfty period. Backfilling may occur as soon as 5 years after 
burial for the HLh or as long as 25 years for the SF under the present conceptual cesign for deep geological djsposal. The most important factors in the thermal analysis of repository models are (1) the initial heat production rate, the distribution, and decay rate of the radioactive waste material, (2) the stratigraphy of the repository, (3) thermal and physical properties of the storage mefium, and (4) boundary conditions including the geothermal flux and the dimensions of the models. The dimensions of the models should be within the range of temperiture propagation. The question of using isothermal or adiabatic boundaries was resolved by using economical one-dimensional solutions in parametric stuodies. Use of these studies was found to be less costly to establish the boundary limits.

The selection and proper use of these factors in relation to models considered will be discussed in later sectic..s.

\subsection{Nefinition of Temperature Terms}

In general the meaning of the cemperature terms referred to in this report are as follows.

1. $L T$ or temperature increase refers to localized temperature increase above a steady-state initial temperature of a given position.

2. Maximum $\Delta T$ or maximum temperature increase is the highest $\Delta T$ with respect to position at any given time.

3. Peak $\Delta T$ or peak temperature increase is the highest $\Delta T$ with respect to time at a given position.

4. Peak maximum $\Delta T$ or peak maxinum temperature increase is the highest $\Delta T$ with respect to time reached at a given location winich $\therefore .1$ so has the highest $\Delta T$ with respect to position. 


\section{SOLUTION TECHNIQUE}

The problem at hand is to determine the transient temperature distributions resulting from a finite decaying heat source in a multiregion finite media for which the thermal diffusivities are moderate functions of temperatures. As long as the boundary conditions and thermisl properties are considered to be ccnstant, analytical solutions can bo considered. Carslaw and Jaeger ${ }^{5}$ have preserted tasic formulatiuns that have been eapanded to geological applications $b$; Ingersoll et al. ${ }^{6} \mathrm{~J}$. P. Nichols ${ }^{7}$ of ORNL developed several unique analytical solutions for conouction in an infinite medium with a decaying heat source by employing Green's function and the method of both superposition and the assumption of instantaneous heat release.

Although analytical solutions can provide insight with respect to physical mechanisms, nimerical techniques must be employed to incorporate the nonlinearities caused by temperature-dependent thermal properias and boundary conditions in a multicomponent medium.

Many general-purpose finite difference and finite element programs are available for the solution of the scnlinear conduction problems. TRURP, ${ }^{3}$ AYER, ${ }^{9}$ and NOHEAT ${ }^{10}$ were several of the :inite element codes considered and offered no apparent advantage over HEATING5, 11 which was used for these irvestigations.

HEATINC,5, the latest modification in a series of HEATING programs, is a general finite difference heat transfer program for both steady-state and transient heat transfer problems in one-, two-, or three-dimensional configurations. All thermal transport properties can be expressed as functions of temperature, and nonlinear boundary corditons car be imposed. Heat generation can be expressed as a function of time and pcsition. The boundary conditions can be specifiec as adiabatic, forced convection, natural convection, radiation, constant temperature, or constant heat flux. The boundary conditions can be temperatur\% and/or time dependent.

Both explicit and implicit techniques are available for the solution of transient heat transfer problem.s. The implicit techniques include the Classical Implicit Procedures (CIP), hackwards Eıler, or Crank-Nicholson. 
The Crank-iiicholson ${ }^{12}$ implicit solution technique was chosen for the transient analyses in these investigations, using an initial time-step of 0.1 year. Cheverton and Turner ${ }^{13}$ give an excellent discussion on various solution techniques, including their assets, liabilities, and economics.

The HEATINGS code has been modified to remove the limits on the size of the arrays used in the input variables and to reduce the core requirements for a given problem. This modified version is designated as HEATING5A, 14 which was used to analyze problems that could not be processed using HEATING5. TRUMP was compared ${ }^{15}$ with HEATING5 and was found to require as much as 100 times the CPU time required to obtain steady-state solutions and as much as 2.5 times the CPU time required tc obtain transient solutions on nonlinear problems as was required using HEATIVGS.

The HEATING programs used at the Union Carbide Corporation installations at Oak Ridge for the past 14 ycars have been found to be accurate, versatile, and dependable and have proved to be beneficjal in obtaining solutions in many tyfes of complex heat transfer problems. 


\section{HEAT SOLRCES AND DECAY RATES}

It is assumed that :he hypothetical repository used in this study should have the capability of storing $133 \mathrm{Mh}$ of 10-year-old SF or HLW by the year 2010, which is close to the $121 \mathrm{MW}$ projected by Kee, Croff, and Blomeke. ${ }^{16}$ The canisters are conservatively assumed to be uniformly and simultaneously loaded in the repository for determination of the heat generation rate of the far-field source. For an $8 U-f t$ room spacing with a canister pitch of $80 \mathrm{ft}$ and a heat load of $160 \mathrm{~kW} / \mathrm{acre}$, Cheverton and Turner ${ }^{17}$ calculated a maximum temperature rise about $10^{\circ} \mathrm{F}$ greater for simultaneous loading than for sequential loading of a repository.

\subsection{Heat Sources lised in the Models for the Preliminary Comparisons}

The far-field heat source for the two-dimensional $P, Z$ models used in the prelimirary comparisons is ubtained by distributing the $133 \mathrm{MW}$ of heat uniformly throughout the repository volume. The 883-acre repository area is determined by distributing the far-field heat source of $133 \mathrm{MW}$ at $150 \mathrm{~kW} /$ acre. The height of the source is assumed to be $10 \mathrm{ft}$ in the preliminary models, yielding a volume of $3.85 \times 10^{8} \mathrm{ft}^{3}$ and an initial heat generation rate of $10,353 \mathrm{Btu} / \mathrm{yr} \cdot \mathrm{ft}^{3}$ for the 10-:ear-olj source. This initial source strength is used for both SF and ILW in the prelininary models.

The unit-cell heat source for the preliminary models for both SF and HLW is based on an initial heat load of $3.50 \mathrm{~kW} /$ canister for 10-year-uld waste. The 10-year-old waste in the unit cell is assumed to have a diameter of $16 \mathrm{in}$. and a height of $10 \mathrm{ft}$, yielding a volume of $13.96 \mathrm{ft}^{3}$ and an initial heat generation rate of $7.49 \times 10^{5} \mathrm{Br} . \mathrm{H} / \mathrm{yr} \cdot \mathrm{ft}^{3}$.

\subsection{Heat Sources Used in the Far-Field Models for the Detailed Comparisons}

The far-field heat source for the models used in the more detailed analyses is obtained by uniformly distributing the 133 MW of heat from 
the 10-year-old waste over the cylindrical source volumes of the models. The volume occupied by the source for the SF model has a radius of $5544 \mathrm{ft}$ (based on an areal heat load of $60 \mathrm{~kW} / \mathrm{acre}$ ) and a height of $12 \mathrm{ft}$ (the active height of a fuel assembly). The resulting homogenized heat generation rate is $3432 \mathrm{Btu} / \mathrm{yr} \cdot \mathrm{fr}^{3}$ for 10 -year-old $\mathrm{SF}$.

In like manner, the volume of the far-field heat source of tilW has a 3500-ft radius (based on an areal heat load of $150 \mathrm{~kW} / \mathrm{acre}$ ) and a heigit of $8 \mathrm{ft}$ (the active height of HLl! in the canister). The resulting homogenized heat generation rate for 10 -year-old $\mathrm{HLW}$ is $12,916 \mathrm{Btu} / \mathrm{yr}^{\circ} \mathrm{ft}^{3}$.

\subsection{Heat Sources Used for the Unit-Cell Models in the Detailed Comparisons}

The heat source used in the unit-cell model for SF is assumed to be a spent pressurized water reactor (PWR) fuel assembly that has been removed from the reactor for 10 years and has a power of $0.55 \mathrm{~kW}$. The source strength of 10-year-old HLW is $2.1 \mathrm{~kW}$. This heat was distributed over separate volumes for the SF and HLW.

The volume of the unit-cell sources for the detailed comparisons as shown in Fig. 4.1 is based on a diameter of $20 \mathrm{in}$. The height of the source used for the SF is $12 \mathrm{ft}$, resulting in a volumetric heat generation rate of $6.27 \times 10^{5} \mathrm{Btu} / \mathrm{yr} \cdot \mathrm{ft}^{3}$. The active height of the HLW is $8.0 \mathrm{ft}$, resulting In a heat generation rate of $3.70 \times 10^{6} \mathrm{Btu} / \mathrm{yr} \cdot \mathrm{ft}^{3}$. The assumption made in these cases is that the crushed salt used as backf $₫ 11$ recrystallizes into the solid form in a relatively short time so that the backfill propertios can be assumed to be the same as those of solid salt.

\subsection{Decay Rates for SF and HLW}

The SF may be in the form of fuel element assemblies from either a pressurized water reactor (PWR) or a bolling water reactor (BWR). In this study, the SF is assume 1 to be from PWRs because of the slower decay of cheir heat geiteration rate, but the power production rates for the BWR assemblies will be shown for compai ison. The power production rates in 
ORNL-DWG 78-5448

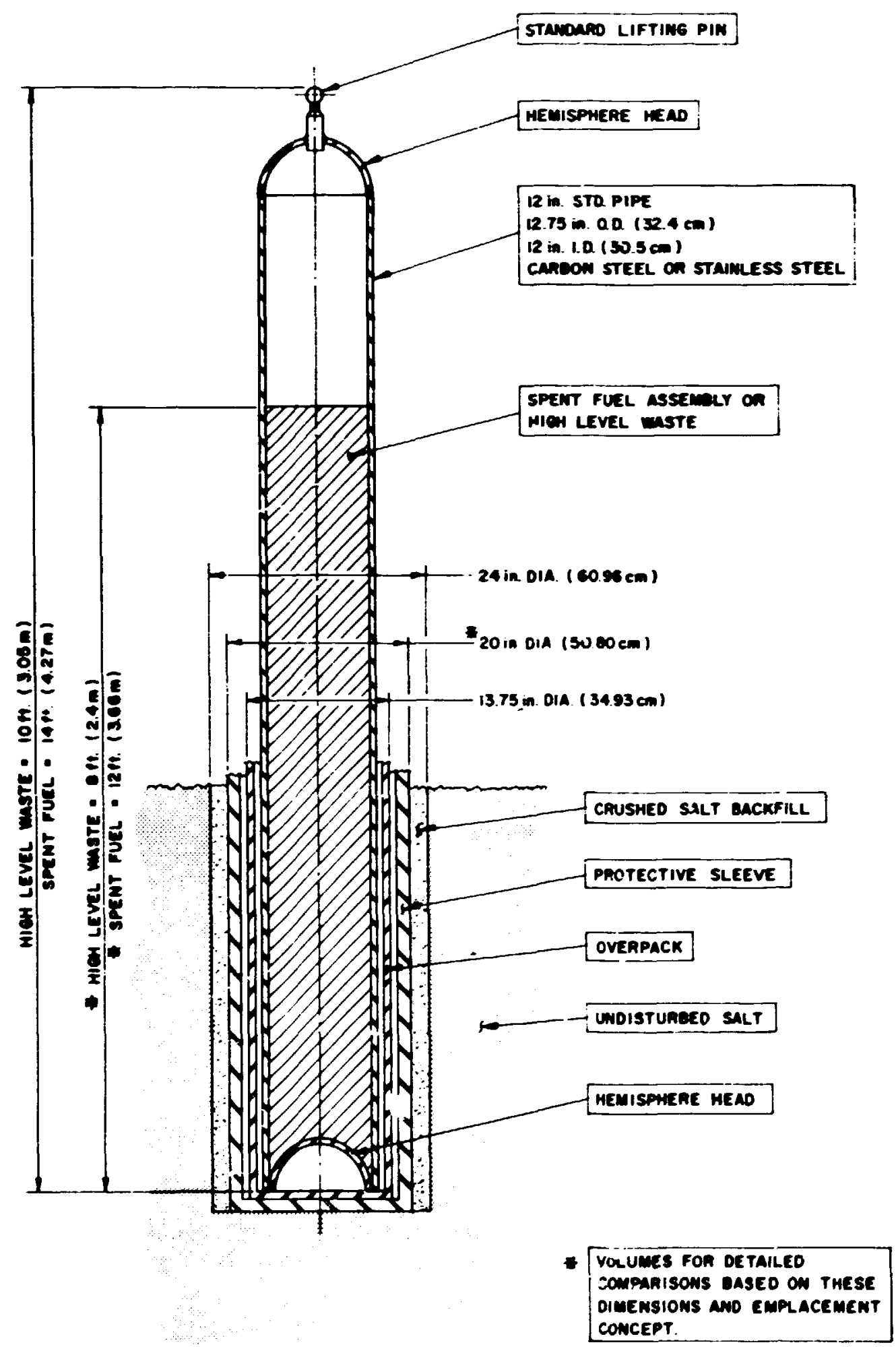

F18. 4.1. Canister emplacement concept for deta1led unit-cell mode1, 
kilowatts are shown in Fig. 4.2 for SF assemblies and HLW canisters as functions of time after reprocessing or discharge from a reactor over a period of 100,000 years.

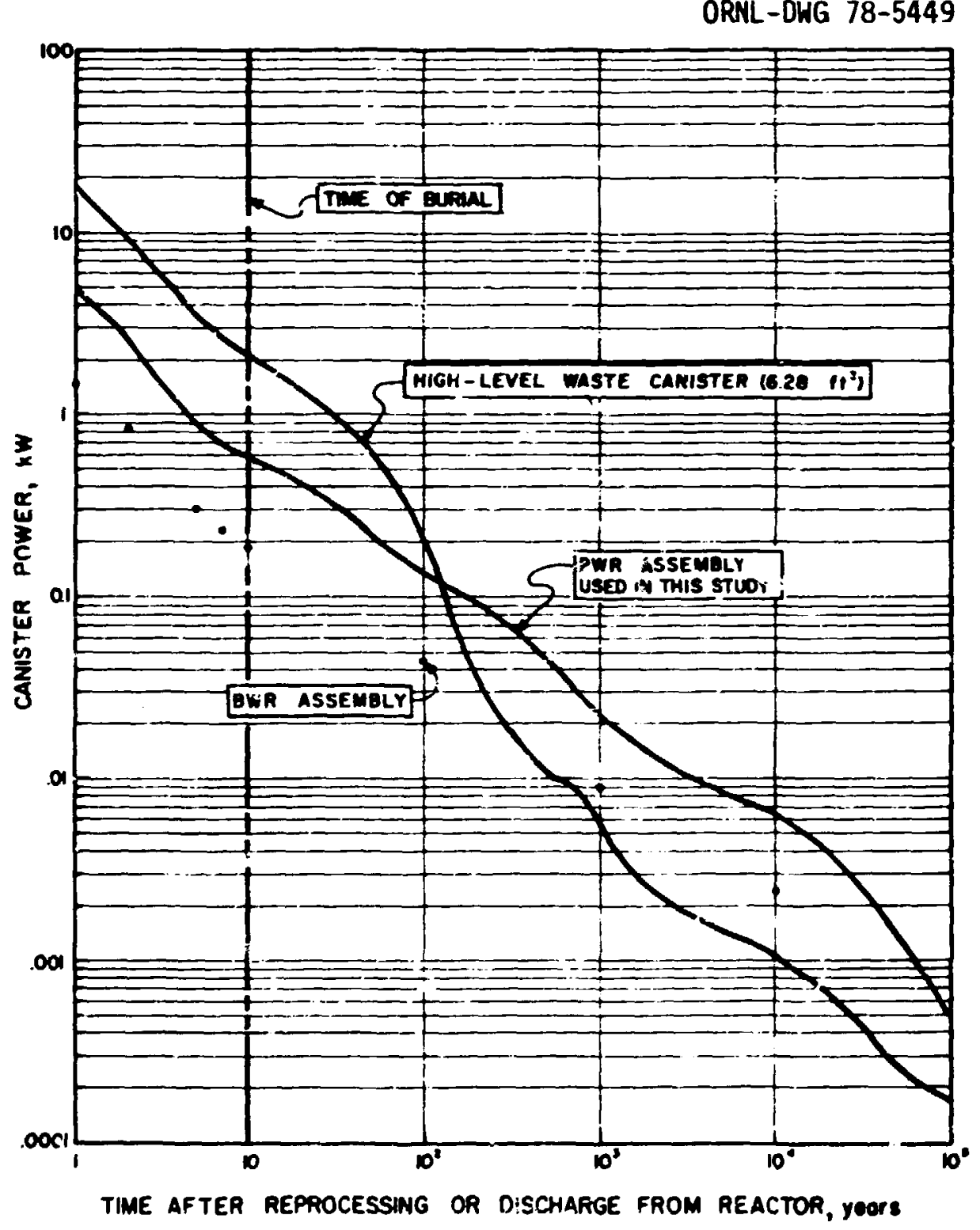

Fig. 4.2. Power production rate for PWK and BWR spent fuel assemblies and 6.28- $\mathrm{ft}^{3}$ canisters fc: HLW as functions $n_{i}$ : lime for periods to 100,000 years. 


\subsection{Normalized Decay Rates}

The heat generation rates of PWR and BWR spent fuel assemblies and HLW were obtained through the use of the ORIGEN ${ }^{18}$ computer program as a function of ilme over a period of 100,000 years. To obtain a dimensionless relationship that can be used to evaluate any given source as a function of time, the data were normalized by dividing the time-dependent heat generation rates by their respective initial values at 1 year. The HLA was also assumed to be aged 160 days prior to processing. The normalized heat generation rates for both SF and HLW are shown in Fig. 4.3.

ORNL-ONG 78-5450

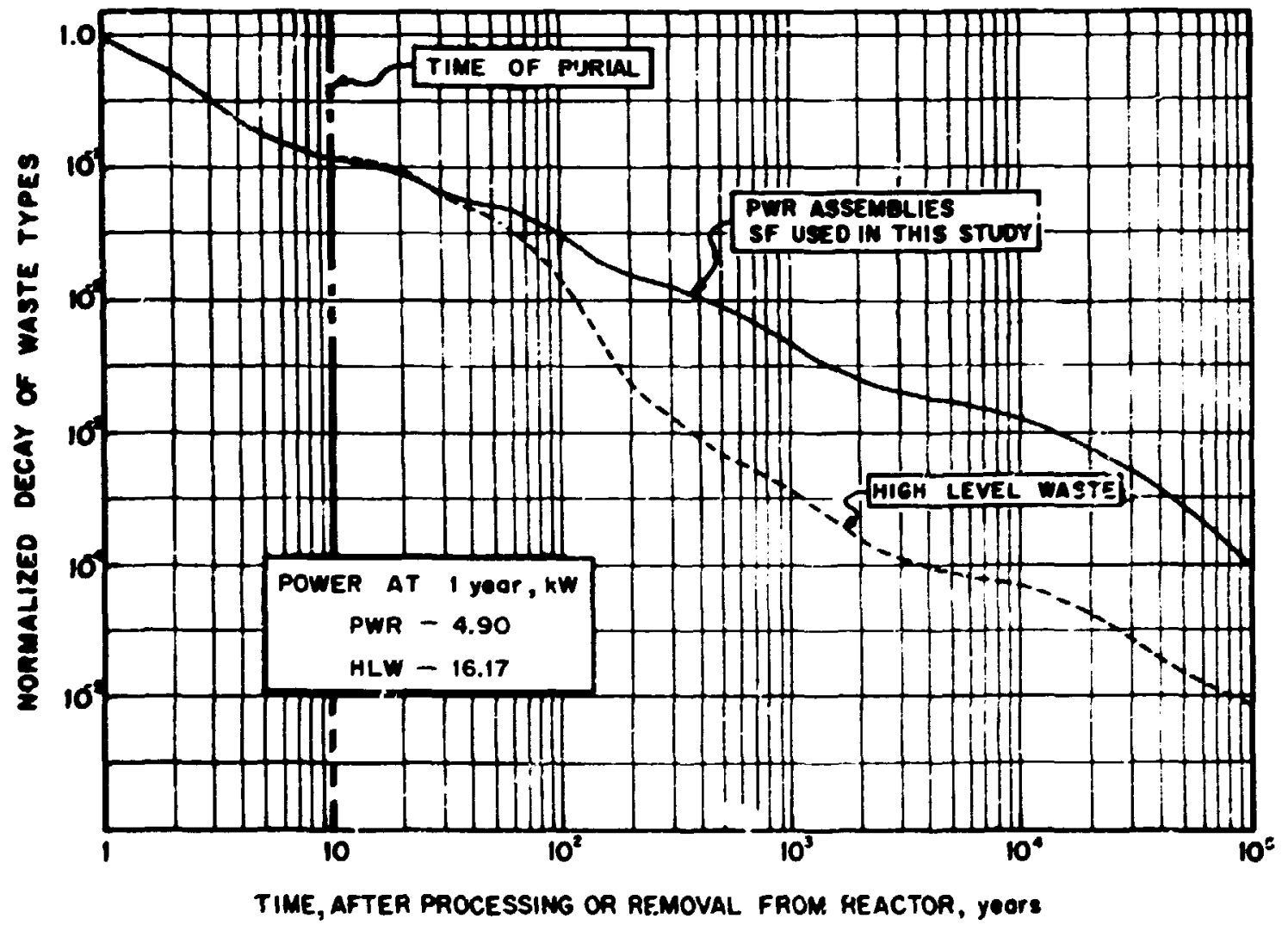
of timp.

Fig. 4.3. Normalized heat generalized for SF and HLW as functions 
During the first 20 years, very little difference exists between the two curves, but the difference steadily increases with time to a point at which the SF is producing heat at a rate as much as 20 times as great as the HLW. The dominating factor in the heat decay is the presence of ${ }^{239} \mathrm{Pu}$, which has a half-life of 24,000 years. The HLW contains only 0.57 as much plutoniun as the SF.

\subsection{Ratio (SF/HLW) Stored Energy as a Function of Time}

It is interesting to compare the integrated power, or energy, of an initially equal power so:rce of $\mathrm{HLW}$ and SF as a function of time. The energy for each waste iype 's obtained by integrating the power as a function of time based on tabulation of the ORIGEN output data for reprocessed HLW and PWR spent fuel assemblies. The ratio (SF/HLW) was obtained by dividing the normalized value obtained for SF by the normalized value obtained for HLW. This ratio (SF/HLW) of energy released as a function of time is shown in Fig. 4.4 This difference between SF and HLW is due to the higher ${ }^{239} \mathrm{Pu}$ content of the SF.

The difference in the upheavals in SF and HLW repositories with the same areal heat loads is priwarily due tc the stcred energy. Thus by reducing the areal heat load of the $S F$ from $150 \mathrm{~kW} /$ acre to $60 \mathrm{~kW} / \mathrm{acre}$, the upheaval was made about equal to that incurred by the HLW stored at $150 \mathrm{~kW} / \mathrm{acre}$. 
ORNL-OWG 78-5451

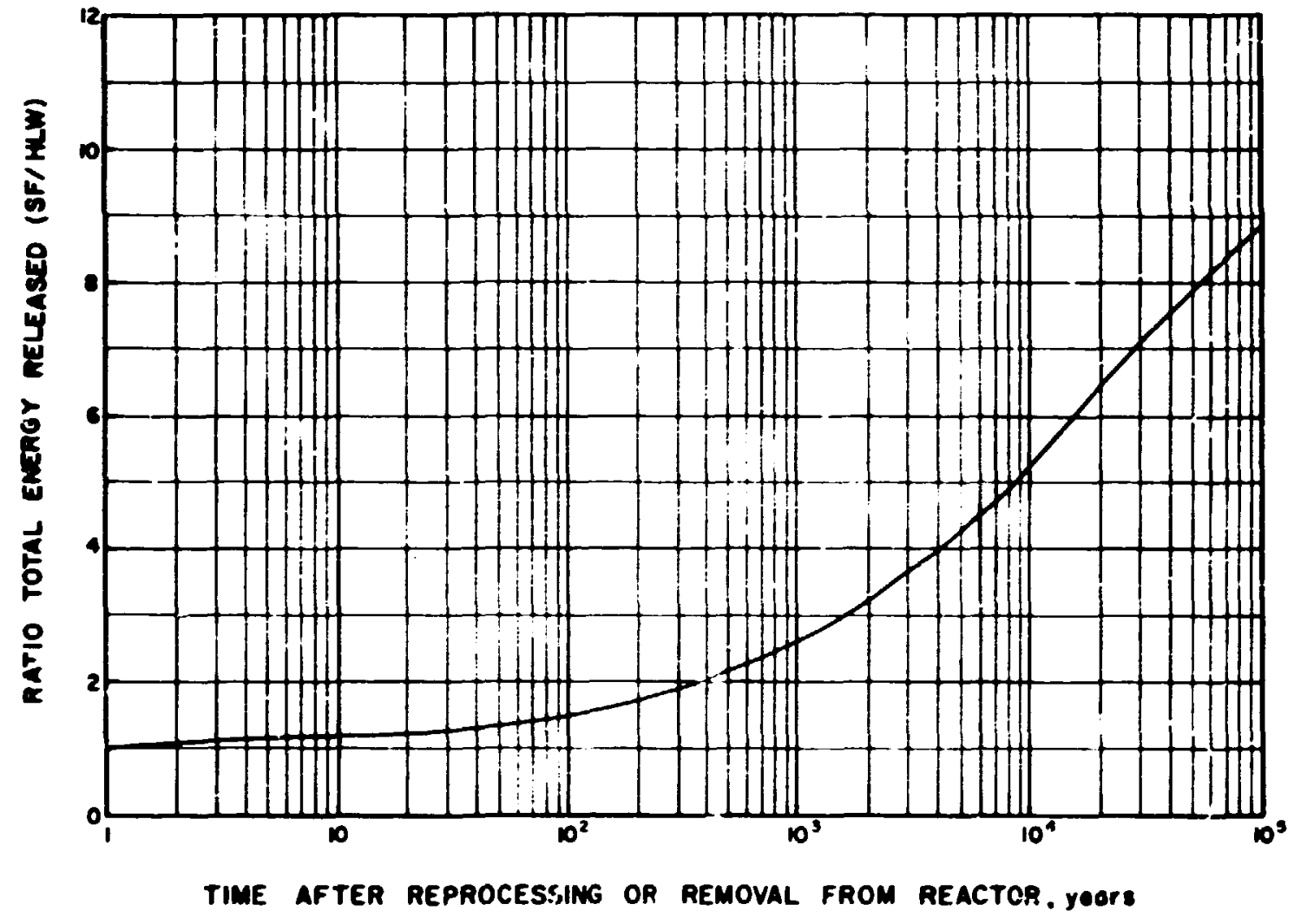

F1g. 4.4. Ratio (SF/HLW) of total energy released as a function of time after reprocessing ur removal from reactor. 


\section{BOUNDARY CONDITIONS}

Boundary conditions required for the heat transfer models used in these Investigations are the surface-alr temperature, heat transfer coeff1clent at the surface, and the prevalling geothermal flux. Dlumel and seasonal perturbations in the bulk alr temperature over the repository are not important in this analysis because these perturbations disappear at depthe below $50 \mathrm{ft} .19$ Consequently, a constant surface-air temperature of $60^{\circ} \mathrm{F}$ has been assuned in these analyses, which 18 close to the mean annual temperature found in the United States.

To evaluate the magnitude of the temperature difference on the surface, the heat transfer coefficient ust be considered. This coefficient is a function of such factors as local terrain, ground conditions, and the temperature and velocity of the alr; the mean value generally varies between 2 and $6 \mathrm{Btu} / \mathrm{hr} \cdot \mathrm{ft}^{2} \cdot{ }^{\circ} \mathrm{F} .20$ A mean value of $4.0 \mathrm{Btu} / \mathrm{hr} \cdot \mathrm{ft}^{2}{ }^{\circ} \mathrm{F}$ was used in these analyses.

Geothermal fluxes in the continental United States ${ }^{2}$ usually range from 53 to $350 \mathrm{Btu} / \mathrm{yr} \cdot \mathrm{ft}^{2}$. A mean geothermal flux of $140 \mathrm{Btu} / \mathrm{yr} \cdot \mathrm{ft}^{2} \mathrm{has}$ been estimted for the land masses and was imposed on the lower axial boundary of all heat transfer models used in this report. ${ }^{22}$

Using a mean surface heat transfer coefficlent of $4 \mathrm{Btu} / \mathrm{hr} \cdot \mathrm{ft}^{2} \cdot{ }^{\circ} \mathrm{F}$, a $\Delta T$ of only $0.004^{\circ} \mathrm{F} 18$ required to dissipate the geothermal flux to the alr by forced convection. A maximum surface $\Delta T$ of $0.01^{\circ} \mathrm{F}$ was calculated in these analyses as required to transfer the heat load by forced convection to the alr. Th1s 1 s only about $2-1 / 2$ times the $\Delta T$ produced by the mean geothermal flux.

Adlabatic conditions have been assumed on the radial boundarles of all of the heet transfer modela. In far-field parametric studies made on the two-dimenstonal models for HLW and SF, the radla, boundary extended to $15,000 \mathrm{ft}$ and $24,000 \mathrm{ft}$ respectively. No appreclabje increase was noted In the initlal boundary temperatures after reaching the final time of 100,000 year 8 . 
6. PHYSICAL PROPERTIES AND INITIAL CONDITIONS

\subsection{Physical Properties}

The physical property data used in these calculations are the same as those used by Cheverton and Turaer ${ }^{23}$ with the exception of the overburden material. The overburdeu that was assumed has constant physical properties with 2 thermal conductivity of $1.0 \mathrm{Btu} / \mathrm{hr} \cdot \mathrm{ft} \cdot{ }^{\circ} \mathrm{F}$, a density of ${ }^{-50} 1 \mathrm{~b} / \mathrm{f} \mathrm{E}^{3}$, and a heat capacity of $0.20 \mathrm{Btu} / 1 \mathrm{~b} \cdot{ }^{\circ} \mathrm{F}$. The shale stz $-a$ ext-ring in the detalled far-field models below a depth of $4000 \mathrm{ft}$ is also assimed to hava constant physical properties identical with those listed for the overbuzden material.

The salt formation is assumed to be halite, which is essentially pure sodium chloride. The heat capacity and density of halite change very little over the temperature range 50 to $500^{\circ} \mathrm{F}$. The heat capacitance of halite is assumed to be constant at $0.22 \mathrm{Btu} / 1 \mathrm{~b} \cdot{ }^{\circ} \mathrm{F}$ and the density constant at $135 \mathrm{lb} / \mathrm{ft}^{3}$. The thermal conductivity of halite used in this report is from data of Birch and Clarke, ${ }^{24}$ who obtained values of $3.53 \mathrm{Btu} / \mathrm{hr} \cdot \mathrm{ft} \cdot{ }^{\circ} \mathrm{F}$ at $32^{\circ} \mathrm{F}$ to $1.20 \mathrm{Btu} / \mathrm{hr} \cdot \mathrm{ft} \cdot{ }^{\circ} \mathrm{F}$ at $732^{\circ} \mathrm{F}$. Thermal conductivities for domed salt were obtained for temperatures up to $1200^{\circ} \mathrm{F}$ by $\operatorname{Smith},{ }^{25}$ who employed a newly developed laser technique. The data obtained by Smith are included for comparison in Fig. 6.1, along with the data obtained by Birch and clarke.

\subsection{Stratigraphy}

The stratigraphy for an actual repository naturally will be site dependent and variable in both horizontal and yertical directions. The stratigraphy employed in this study is hypothetical, and certain simplifying assumptions have been made for the purpose of modeling the repository.

The model overburden used in the preliminary investigations was assumed to extent to a depth of $800 \mathrm{ft}$, with halite extending below this point to a depth of $24,000 \mathrm{ft}$. The thermal conductivity of the halite is assumed to be a function of temperature.

The stratigraphy assumed for the detalled far-field models assumes a constant physical property overburden to a depth of $800 \mathrm{ft}$. A strata 
ORNL-DNG 78-5437

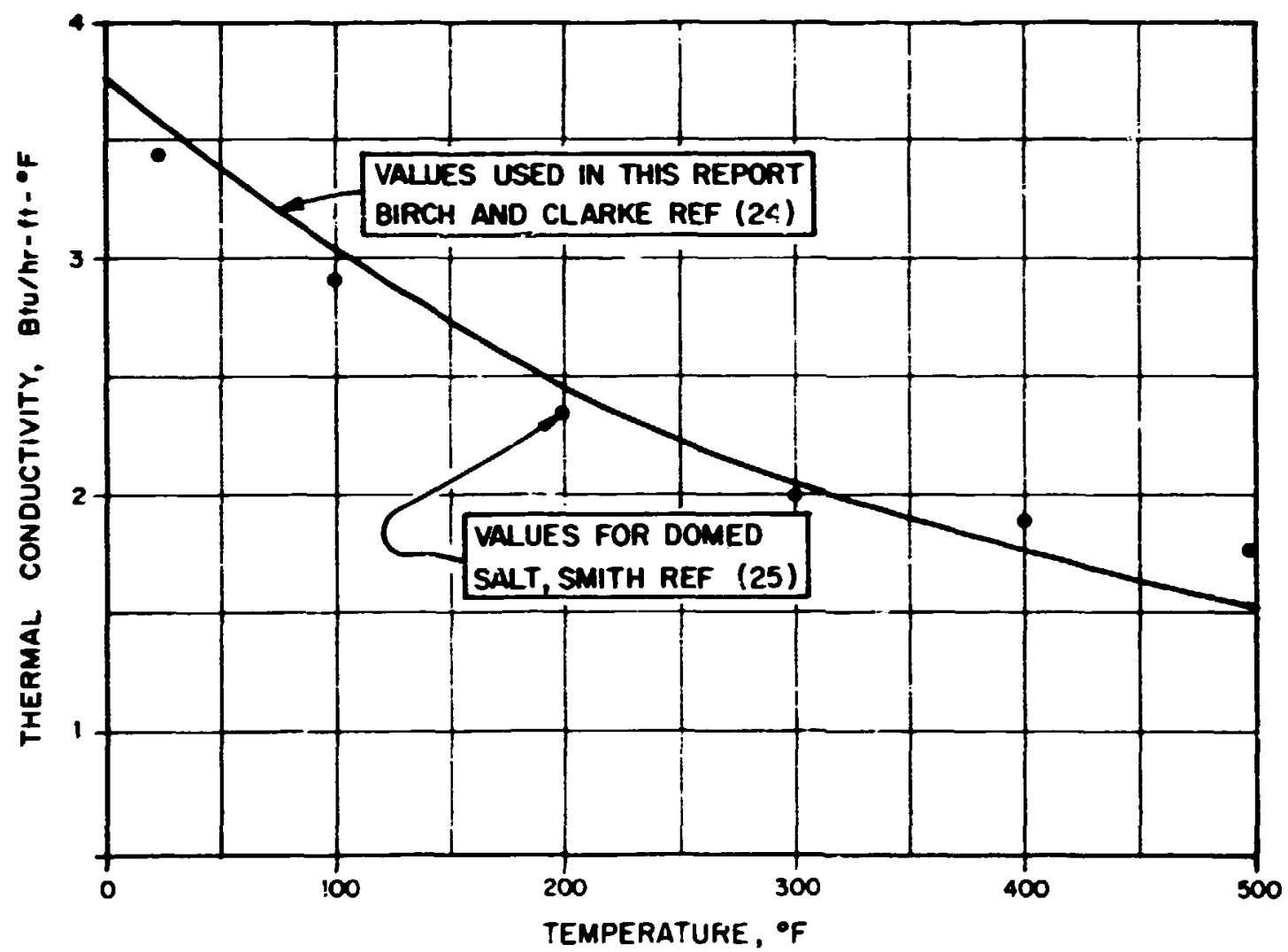

F1g. 6.:. Thermal conductivity of halite and domed salt as functions of temperature.

of halite is assumed from $800 \mathrm{ft}$ to a depth of $4000 \mathrm{ft}$. Shale $1 \mathrm{~s}$ assumed to exist from the 4000-ft elevation downward to the 24,000-ft elevation.

The stratigraphy is an important factor in establishing an initial geothermal gradient as will be discussed In Sect. 6.3. When actual repository sites have been identifled, finer definition of tihe stratigraphy can be made.

\subsection{Inttial Temperature Distribution}

The geothermal flux and thermal conductivity were used to obtain initial temperature distributions from a one-dimensional steady-state heat transfer model based on the assumed stratigraphies of the far-field models 88 mentioned in Sect. 6.2. The resulting inftial thermal gradients used In the models are show in F1g. 6.2. Nonlinear gradients are encountered 
ORNL-DWG 78-5456

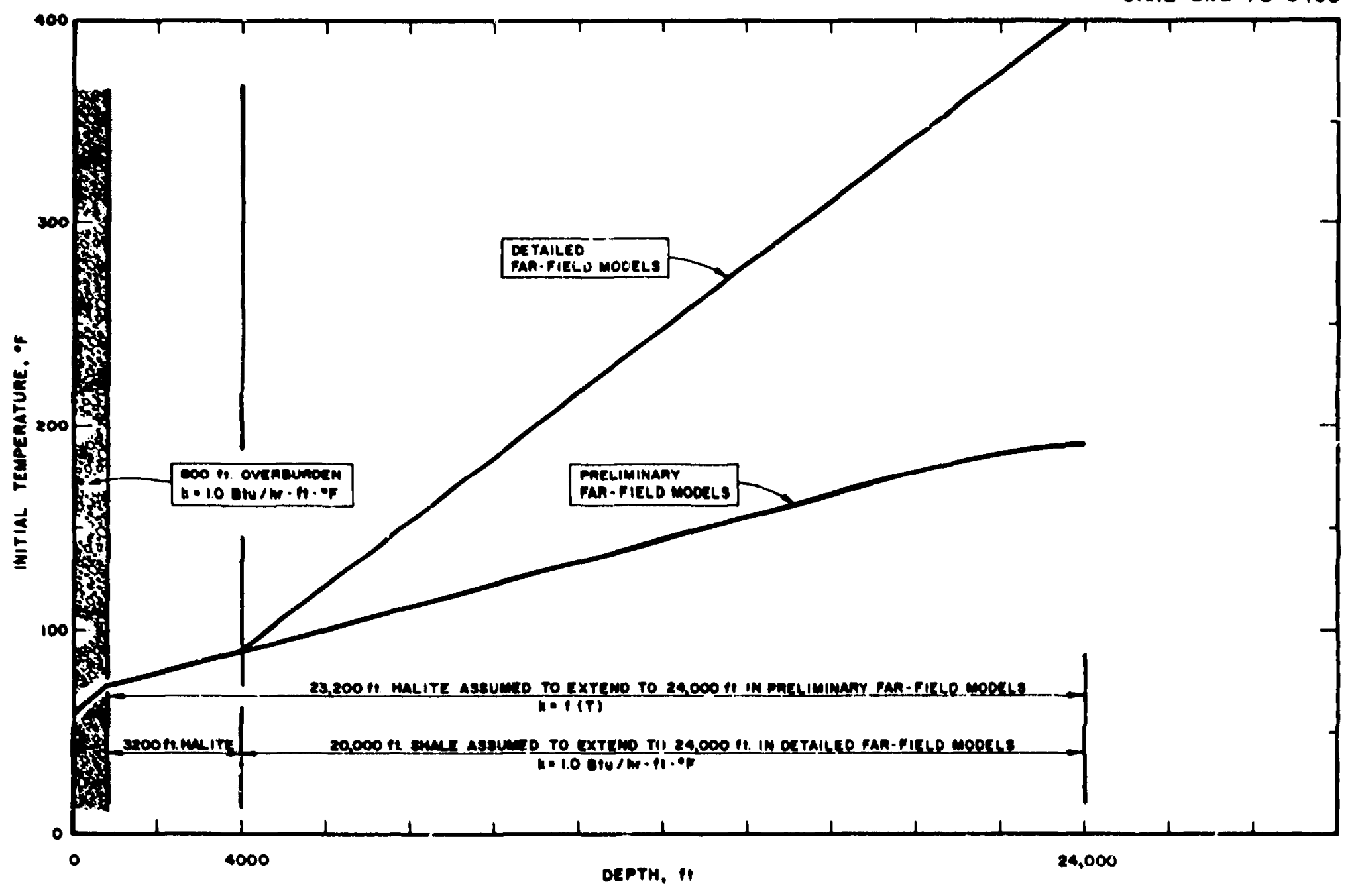

F1g. F.2. Geothermal gradients. 
for which the thermal conductivity is a function of temperatire; these gradients are more apparent where larger :emperature deviations vicur.

A geothermal gradient of $0.016^{\circ} \mathrm{F} / \mathrm{ft}$ was calculated for the overburden and shale, whereas $0.0054^{\circ} \mathrm{F} / \mathrm{ft}$ was calculated for the salt region. This agrees reasonably well with the range of geothermal gradients of 0.006 to $0.06^{\circ} \mathrm{F} / \mathrm{ft}$ (ref. 26) in the continental United States. Jessop et al. 27 complied and listed the geographic coordinates, depth, ti.ermal conductivity, geotheraal flux, geotherwal gradient, and other pertinent stratigrapic information for each location. 
7. PRELIMINARY COAPARISONS OF SF AND HLW A? $150 \mathrm{kH} /$ ACRE AND $3.5 \mathrm{kH} /$ CANISTER

It was desired to determine the effect of the difference in decay rates of SF and HLW by direct comparison at an initial heat load of $150 \mathrm{kH} /$ acre and $3.5 \mathrm{kH} /$ canister, which was previously found acceptable for iIL. 28 Two basic heat transfer models vere used in the preliminary analysis of the terminal storage of radioactive vaste material in salt repositories. A two-dimensional far-field model that uses a homogenized heat source vas created. This model, which includes the refository region, represents an area of over $25 \mathrm{sq}$ miles and 18 thought to be adequate for predicting temperatures in long-term transients outside tine Immedlate vicinity of the repository. However, tnis model does not have the capabilIty to Indicate local maximum selt temperatures sur rounding each canister. For this reason, a near-field or unit-cell model was created in which a pro rata share of the total rapository area was allocated to each canister. The unit-cell model is based on a single canister heat load of $3.5 \mathrm{kH}$ for both SF and HLW. The area of the far-field model, which encompasses over 16,090 acres, represents the surface area of the total repository; the area of the unit-cell model represents only the area associated with a single canister.

The comparative models for the prelimanary cases were supplied with Identical boundary conditions and initiai heat sources, and only the decay rates of the SF and HLW heat sources were different.

The models and the geometry have been kept simple; properties and initial heat are identical for the purpose of comparing temperature increases in the repository brought aoout from :he storage of SF or HLW. The two-dimensional models should be adequate for comparison of far-field effects and for rough estimations of maximum anticipated cemperatures in the salt. The unit-cell and far-field models were used to analyze four preliminary cases: (1) far-field with ST (case A), (2) far-field with HLW (case B), (3) unit-cell with SF (case C), and (4) unit-cell with HLW (Case D), as summarized in Table 7.1. 
Table T.1. Two-dimenglonal $R, Z$ computer models for preliminary comparlsons - cases A through $D$

\begin{tabular}{|c|c|c|c|c|}
\hline Item & Case A & Case B & Case C & Case D \\
\hline 10-year-old waste type & SF & HILW & $\mathbf{S F}$ & HL.W \\
\hline Model & Far-f $\_$eld & Far-field & Undt-cell & UnIt-cell \\
\hline Transient, years & $1.0 \times 10^{5}$ & $1.0 \times 10^{5}$ & 1500 & 4500 \\
\hline Thermal load, kli/acre & 150 & 150 & 150 & 150 \\
\hline Source heat at 10 years, $\mathrm{kW}$ & 133,000 & 133,000 & 3.5 & 3.5 \\
\hline Source area, $\mathrm{ft}^{2}$ & $3.85 \times 10^{7}$ & $3.85 \times 10^{7}$ & 1.40 & 1.40 \\
\hline Source helght, ft & 10 & 10 & 10 & 10 \\
\hline Source volume, $\mathrm{ft}^{3}$ & $3.85 \times 10^{8}$ & $3.85 \times 10^{8}$ & 14.00 & 14.00 \\
\hline Inttial HGR, Btu/year $\cdot \mathrm{ft}^{3}$ & 16,333 & 10,333 & $7.49 \times 10^{6}$ & $7.49 \times 10^{6}$ \\
\hline Number of canisters & 38,000 & 38,000 & 1 & 1 \\
\hline Peak $\Delta T,{ }^{\circ} \mathbf{F}$ & 259 & 218 & 337 & 301 \\
\hline Time to reach peak $\Delta T$, years & 40 & 60 & 20 & 40 \\
\hline
\end{tabular}


7.1 Two-Dimensional Far-Field Model Used in the Preliminary Comparisons - Cases $A$ and $B$

One-dimensional preliminary parametric studies indicated that a twodimensional model with the radial boundary extending to $15,000 \mathrm{ft}$ and the depth extending to $24,000 \mathrm{ft}$ is needed in order tc obtain near isothermal boundaries throughout the 100,000-year transient.

The 133-MW heat source used in the far-fleld mode! for cases $A$ and $B$ extends radially outward to $3500 \mathrm{ft}$; it begins at $1990 \mathrm{ft}$ below the surface and extends to zuvjo $\mathrm{ft}$. The thermal properties of the heat generation zones are assumed to be the same as those of the sal: because only $1 \%$ of the entire volume actually consists of material other than salt. Repository mediun temperatures are of primary interest in this investigation, and properties assumed for the waste will not affect these results.

The top surface of the overburden is assumed to be cooied with $60^{\circ} \mathrm{F}$ air, which is formulated in the model as a forced convection surface bourdary condition with a heat transfer coefficient of $4 \mathrm{Btu} / \mathrm{hr} \cdot \mathrm{ft}^{2} \cdot{ }^{\circ} \mathrm{F}$. The calculated initial cemperature distribution was imposed on the model as a function of the depth below the sucface. A constant geothermal flux of $0.016 \mathrm{Btu} / \mathrm{hr} \cdot \mathrm{ft}^{2}$ was 1mposed and maintalned at the base of the model. The outer radial boundaries were considered to be adiabatic.

\subsection{Two-Dimensional Unit-Cell Model Used in Preliminary Comnarisons - Cases $C$ and $D$}

The near-field temperatures were calculated wh the use of a twodimensional cylindrical $(R, Z)$ heat transfer modei for cases $C$ and $D$ that has an adiabatic boundary at a ridius of $18 \mathrm{ft}$, simulating a single unit cell and an initial canister heat load of $3.5 \mathrm{~kW}$. The $18-\mathrm{ft}$ unft-cell radius was assumed on the basis of a thermal loading of $150 \mathrm{~kW} / \mathrm{acre}$. The deptin of the model $1 \mathrm{~s}$ taken to be only $4000 \mathrm{ft}$ because long-term results are not pertinent in the near-field calculations. The cylindrical heat source used in this model has a $0.67-f t$ radiu. and is located vertically between 1990 and $2000 \mathrm{ft}$, which is the same vertical location as in the far-field model. 


\subsection{Midplane Temperature Increases Calculated for the Preliminary Comparisons}

Salt temperature increases obtained in the repository are shown in Fig. 7.1 as a finction of time for ali four preliminary cases. These peak rises occur on the horizontal midplanes at a depth of $1995 \mathrm{ft}$ at the centerline in cases $A$ and $B$ and at the salt-waste interface at a depth of $1996 \mathrm{ft}$ in cases $C$ id $D$. A maximum fncrease in temperature of $337^{\circ} \mathrm{F}$ occurring 40 years after emplacemcnt was noted in case $C$ for SF, which corresponds to a maximum temperature of $416^{\circ} \mathrm{F}$. A maximum temperature increase of $j \bar{u}^{\wedge} \bar{r}$ for the HLW occurs 20 years af ter emplacement, yielding a maximum zemperature of $379^{\circ} \mathrm{F}$ in case $D$. After 40 years, the peak increase in case $D$ is reduced to $279^{\circ} \mathrm{F}$. Peak temperature increases in the SF lagged the peaks for the HLW by 20 years in both the far-field and unit-cell calculations. The far-field analysis yielded a $41^{\circ} \mathrm{F}$ higher peak for the SF (case A) than for the HLW (case $B$ ), and a $36^{\circ} \mathrm{F}$ higher peak was determined for the unitcell calculation. A $5^{\circ} \mathrm{F}$ increase is still present for SF in case A even after 100,000 years, whereas less than $]^{\circ} \mathrm{F}$ increase was noted at the same time for HLW in case 3.

Although Fig. 7.1 shows that the temperature increases resulting from SF and HLW decrease after 40 and 20 years, respectively, the net difference between the two curves increzses with time, achieving a maximum temperature difference of about $150^{\circ} \mathrm{F}$ after 600 years. Peaks occur earlfer in the unit-cell. analysis than in the far-field analysis because the adiabatic boundary on the relatively small unit-cell radius restricts radial heat flow and because the unit cell has a lower heat capacity and causes the peak to be :eached sooner.

Figure 7.2 shows the increase in temperature at a depth of $2000 \mathrm{ft}$ on the edge of a repository containing either $F F$ or HLW. The edge of the respository referred to in Fig. 7.2 is at a radius of $350 \mathrm{ft}$. A peak zemperature rise of $115^{\circ} \mathrm{F}$ is produced 55 years after emplacement of SF, whereas a peak $\mathrm{r}$ ise of $98^{\circ} \mathrm{F}$ is produced in 35 years in the repository contalning HLW. 


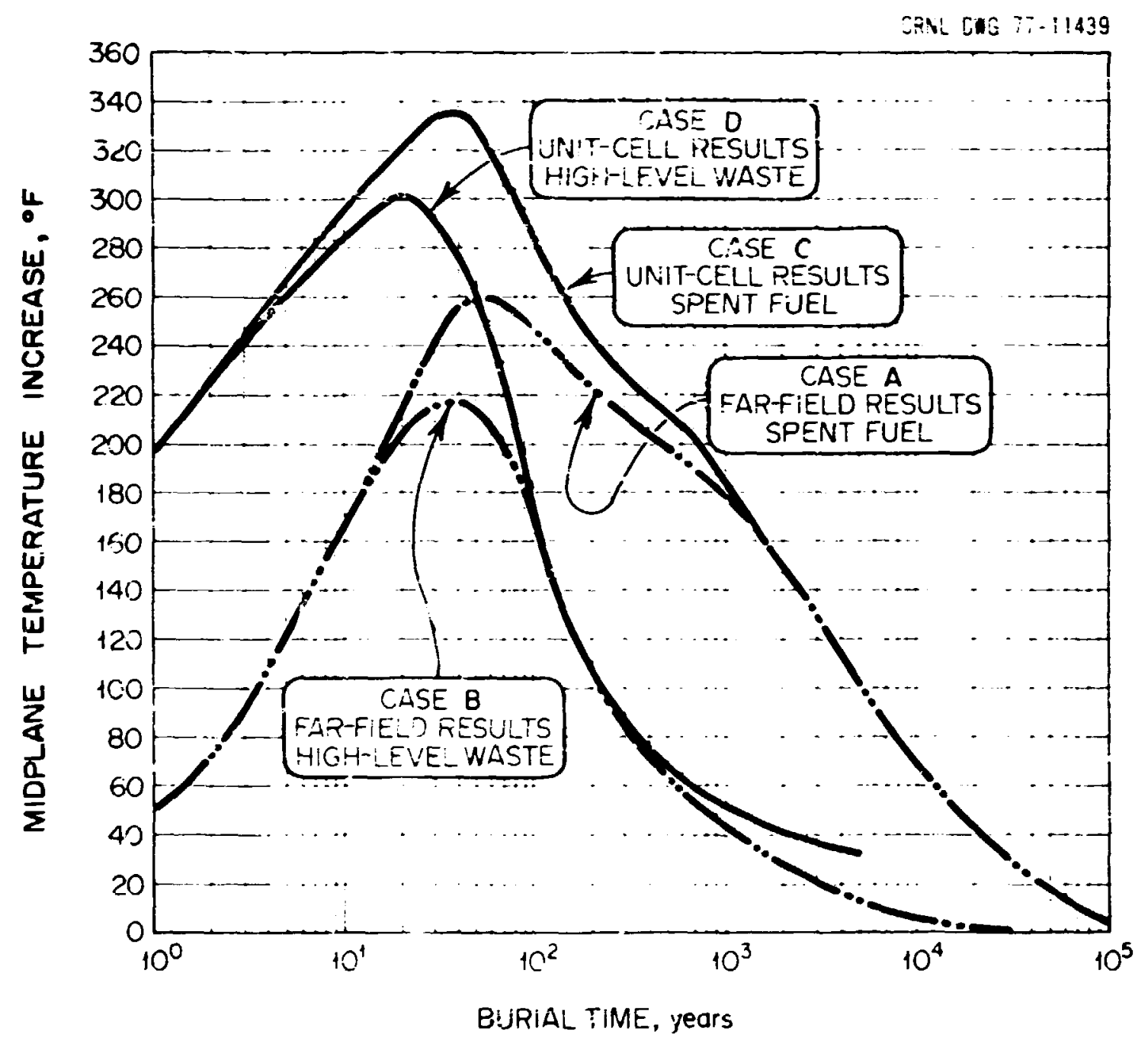

Fig. 7.1. Midplane temperature increases in salt as functions of burial time for cases A, B, C, ind D. 


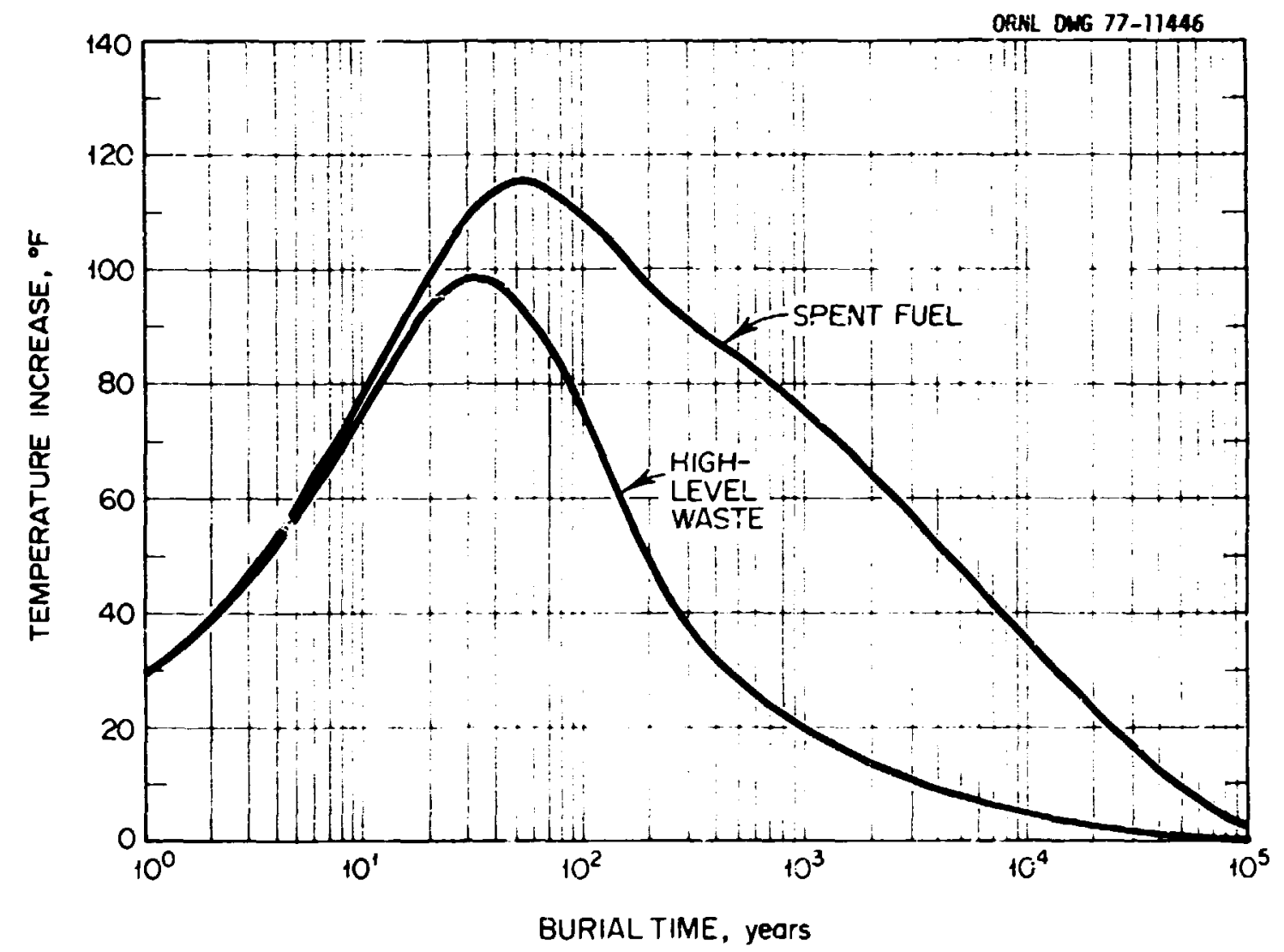

Fig. 7.2. Temperature increases at a depth of $2000 \mathrm{ft}$ at the edge $\mathrm{cf}$ a repository containing SF or HLW as a function of burial time. 


\section{HEAT TRANSFER MODELS FOR DETAILED COMPARISONS OF SF STORED AT $60 \mathrm{~kW} /$ ACRE AND $0.55 \mathrm{~kW} /$ CANISTER AND HLW STORED AT $150 \mathrm{~kW} /$ ACRE AND $2.1 \mathrm{~kW} /$ CANISTER}

From the results of the preliminary cumparisons, it was found that when SF and HLW are stored with the same Initial heat load of $150 \mathrm{~kW} / \mathrm{acre}$ and canister heat of $3.5 \mathrm{~kW}$, the temperatu.. risas produced are sbout $20 \%$ higher for SF than for HLW. It was necessary to reduce the Inftial heat load of the 10-year-old SF by 607 in order to produce corresponding farfield thermal effects (accumulative thermal energy and upheaval) as predicted for the lU-year-old HLW initially loaded at $150 \mathrm{~kW} /$ acre. The initial heat production rate and the heat source volumes for both the unitcell and far-field modeis were assumed to be identical in the prelimirary models disclissed in Sect. 7. The detalled models are based on heat production rates at the time of burlai of $2.1 \mathrm{~kW} /$ canister and $150 \mathrm{~kW} /$ acre for the $\mathrm{HLW}$ and $0.55 \mathrm{~kW} /$ canister and $60 \mathrm{~kW} /$ acre for the $\mathrm{SF}$ as contemplated in current repository design concepts. One-dimensional far-field models were formulated to make parameter studies in transient analysis and to provide the Inftial temperature distribution fror steady-state analysis.

Two- and three-dimensional unit-cell models were formulated to study the near-field temparature increases associated with a single canister. One- and two-dimensional far-field models were created and used primarily to predict the temperature increases remote from the heat source such as the earth's surface or several thousand feet from the repository. A multiple row model was devejoped as a second supportive two-diciensional far-field modei and provides scme currespondence between the unit-cell and far-fiel.d rodeis.

The three-dimensional models using Cartesian geometry were originally created for the single purpuse of providing the capability of modeling a repositcry room with internal heat transfer between the floor and celling.

Sections 8.1 through 8.4 are devoted to the comparisons of temperature increages incurred from storage of either SF or HLW at the previously speciffed heat rates. The pertineut chicracterisifcs of ihe nine cases run in the detailed analysis are summarized in Table 8.1. Intimate contact has been assumed between the heat source and the solid salt in all of the unitcell models used in this stidy. A conservative steady-state calculation 
Table 8.1. Compuce: model for decalled compertmons - cases O ehrough,

\begin{tabular}{|c|c|c|c|c|c|c|c|c|c|}
\hline Ites: & Case 0 & Case 00 & Casee 1 & Case 2 & cane 3 & Case 4 & Case 5 & Case 6 & Case 7 \\
\hline 10-year-old waste type & SF & HLW & SF & HLW & $\mathbf{S F}$ & HLW & $\mathbf{s p}$ & HLW & HLW \\
\hline Configuration & & & 20 & 20 & $2 \mathrm{D}$ & 2D & 30 & 3D & 2D aultiple row \\
\hline Model & Far-fleld & Far-tield & Far-fleld & Far-fiald & Untr-cell & Unit-cel1 & Unte-csild & Unde-cols & Far $-f 1 \in 1 d$ \\
\hline Coordinate system & & & $k:$ & $R^{2}$ & $R^{2}$ & $i z$ & $x \%$ & $X Y Z$ & $x z$ \\
\hline Transient, jears & $1.0 \times 10^{5}$ & $1.0 \times 10^{5}$ & $1.0 \times 10^{5}$ & $10 \times 10^{5}$ & 100 & 200 & 35 & 35 & 100 \\
\hline Inermal load, kW/acre & & & 60 & 150 & 60 & 150 & 60 & 1.0 & 150 \\
\hline $\begin{array}{l}\text { Source heat at } 10 \text { years, } \\
\text { kW }\end{array}$ & & & $133,0.00$ & 133,000 & 0.55 & 2.10 & 0.55 & 2.10 & 133,000 \\
\hline Source area, $f t^{2}$ & 1 & 1 & $9.66 \times 10^{7}$ & $3.85 \times 10^{\%}$ & 2.26 & 2.18 & 2,18 & 2.28 & $7.82 /$ canlacer \\
\hline Source height, ft & 12 & 8 & 12 & 8 & 12 & 8 & 12 & 8 & 8 \\
\hline Source volume, $\mathrm{fr}^{\mathrm{d}}$ & & & $1.16 \times 10^{9}$ & $3.08 \times 10^{8}$ & 26.18 & $17.4 !$ & 26.18 & 17.45 & $62.56 /$ canleter \\
\hline $\begin{array}{l}\text { Source HCR at } 10 \text { years. } \\
\text { Btu/yr-ft }{ }^{3}\end{array}$ & 3432 & 12,916 & 3432 & 12,916 & $6.27 \times 10^{5}$ & $3.60 \times 10^{6}$ & $6.27 \times 10^{5}$ & $3.60 \times 10^{6}$ & $1.0 \times 10^{6}$ \\
\hline Source radlus, if & & & 5544 & 3500 & 0.83 & 0.83 & & & \\
\hline Model radius, it & & & 24,000 & 15,000 & 11.26 & 13.92 & & & \\
\hline Model helght, ft & & & $0-24,000$ & $0-24,000$ & $0-4000$ & $0-4000$ & $2000-3000$ & $1000-3000$ & $800-4000$ \\
\hline Model wldLh, ft & & & & & & & 39 & 39 & 4000 \\
\hline Model depen & & & & & & & 2.56 & 3.91 & Infinite \\
\hline Canisters & & & 242.259 & 63.333 & 1 & 1 & 1 & 1 & 63.334 \\
\hline Peak $\Delta T, \cdot F$ & 100 & 224 & 101 & 223 & 105 & 269 & 113 & 301 & 239 \\
\hline Tiwe to reach peak, years & no & 35 & 60 & 35 & so & 25 & 35 & 20 & 27 \\
\hline
\end{tabular}


shows that no more than $20^{\circ} \mathrm{F}$ radial iI may occur across a 2-in. eznular ring of solid halite. Crushed salt has only $10 \%$ of the initial thermal conductivity of solid salt. Using a 2-1n. backfill of crished salt in the annular volume could Increase surface temperatures of the canister by $200^{\circ} \mathrm{F}$. The temperature of the undisturbed salt, however, would remain unchanged. Experiven:s ${ }^{29}$ indicate that the salt will eventually resolidify; tie rate of resolidification is dependent on temperature, molsture content, and pressure. This theory may be confirmed by the in situ rock mechanics experiments using electrical heat sources in a domed salt formation which are currently belag planned by the office of Waste Isolation.

\subsection{One-Dimensional Far-Field Models (Cases 0 and 00 ) and Results}

Simple one-dimensional far-field models were formulated assuming an 800-ft overburden with constant thermal properties, a 3200-ft hallte strata that extends $4000 \mathrm{ft}$ below the earth's surface, and with shale extending to the base of the model at a depth of $24,000 \mathrm{ft}$. The properties of this stratigraphy are listed in Sect. C. The boundary conditions used on this model are a forced-convection surface heat transfer coefficient of $4 \mathrm{Btu} / \mathrm{hr} \cdot \mathrm{ft}^{2} \cdot{ }^{\circ} \mathrm{F}$ to $60^{\circ} \mathrm{F}$ ambient air and a geothermal flux of $140 \mathrm{Btu} / \mathrm{yr} \cdot \mathrm{ft}^{2}$ imposed at the 24,000-ft depth. These same boundary conditions and st=atigraphy have been employed on the two-dimenstonal far-fiejd models. The primary purpose of the one-dimensional models was to obtain a steady-state temperature distribution utilizing cnly the geothermal flux; this model requires no additional heat source. This temperature distribution, as previously shown in Sect. 4, has been used as the inftial temperature distribution in all models used in the detalled analysis.

The one-dimensional models have also been used in parametric studies to establish the extent of the boundaries necescary for the farfield models based on the rate of temperature propagation. The initial volumetric heat generation rate used in these cases is the same as that used for the two-dimensional far-field sources developed in Sect. 4. The inftial volumetric heat generation rate for a homogenized fuel zone containing 10-year-old SF is $3432 \mathrm{Btu} / \mathrm{yr} \cdot \mathrm{ft}^{3}$; this zone extends from a depth of $2010 \mathrm{ft}$ to $2022 \mathrm{ft}$, which sinulates the active canister height of $12 \mathrm{ft}$. 
Ti:e initial volumetric heat generation rate for $\mathrm{HLW}$ is $12,869 \mathrm{Btu} / \mathrm{yr} \cdot \mathrm{ft}^{3}$; this zone extends from a depth of $201 \mathrm{C} t$ to $2018 \mathrm{ft}$, which simulates an 8-ft active fuel height.

Initial temperature distributions - the main puryose for running these models - were obtained from steady-state analysis of the prelimirary and detafled models. The results have been discussed in Sect. 6.3 and shown in Fig. 6.2. In addition, parametric runs have been made with these models to establish model boundary limits. Peak temperature fucreases obtained as a :esult of these runs at various depths below the surface for both $S F$ and HLW are shown in Fig. 8.1. These remperature increases do nol represent maximum increases ( $\Delta T s$ ) because of the assumption of homogenization of the heat generating zore, but they show the general temperature distribution expected remote from the heat source. These models show that there is only a small temperature increase $500 \mathrm{ft}$ away from the source at their peaking trmes.

\subsection{Two-Dimensional Homogenized Far-Field Model}

(Cases 1 and 2) and Numerical Results

The two-dimensional far-field models are desizned to obtain temperature increases at remote points from the repository for the purpose of environmental or ecological justification. The models must extend from the repository to the eartin's surface. From one-dimensional parametric studies, it was found that the lower axial boundary must be about $s$ ix times the depth of the repository. The radial boundary of the model must extend to about four repository radil in order to maintain isothermal boundaries during a 100,000-year transient with adiabatic boundary conditions.

The first $300-\mathrm{ft}$ depth of the models is assumed to be overburden with constant physical properties. Pure halite is assumed to exist from $800 \mathrm{ft}$ to a depth of $4000 \mathrm{ft}$. The thermal conductivity of the halfte is assumed to be a function of temperature. Shale is assumed to begin at an elevation of $4000 \mathrm{ft}$ and extend to $24,000 \mathrm{ft}$. Physical properties used in these models are given in Seci. 6.1.

A geothermal heat flux of $140 \mathrm{Btu} / \mathrm{yr} \cdot \mathrm{ft}^{3}$ is imposed at the base of the model, an? heat is constantly removed at the earth's surface by torced convectior. With a heat transfer coefficient of $4.0 \mathrm{Btu} / \mathrm{hr} \cdot \mathrm{ft}^{2} \cdot{ }^{\circ} \mathrm{F}$ to $60^{\circ} \mathrm{F}$ ambler.t air. 
ORNL-DNG 78-5457

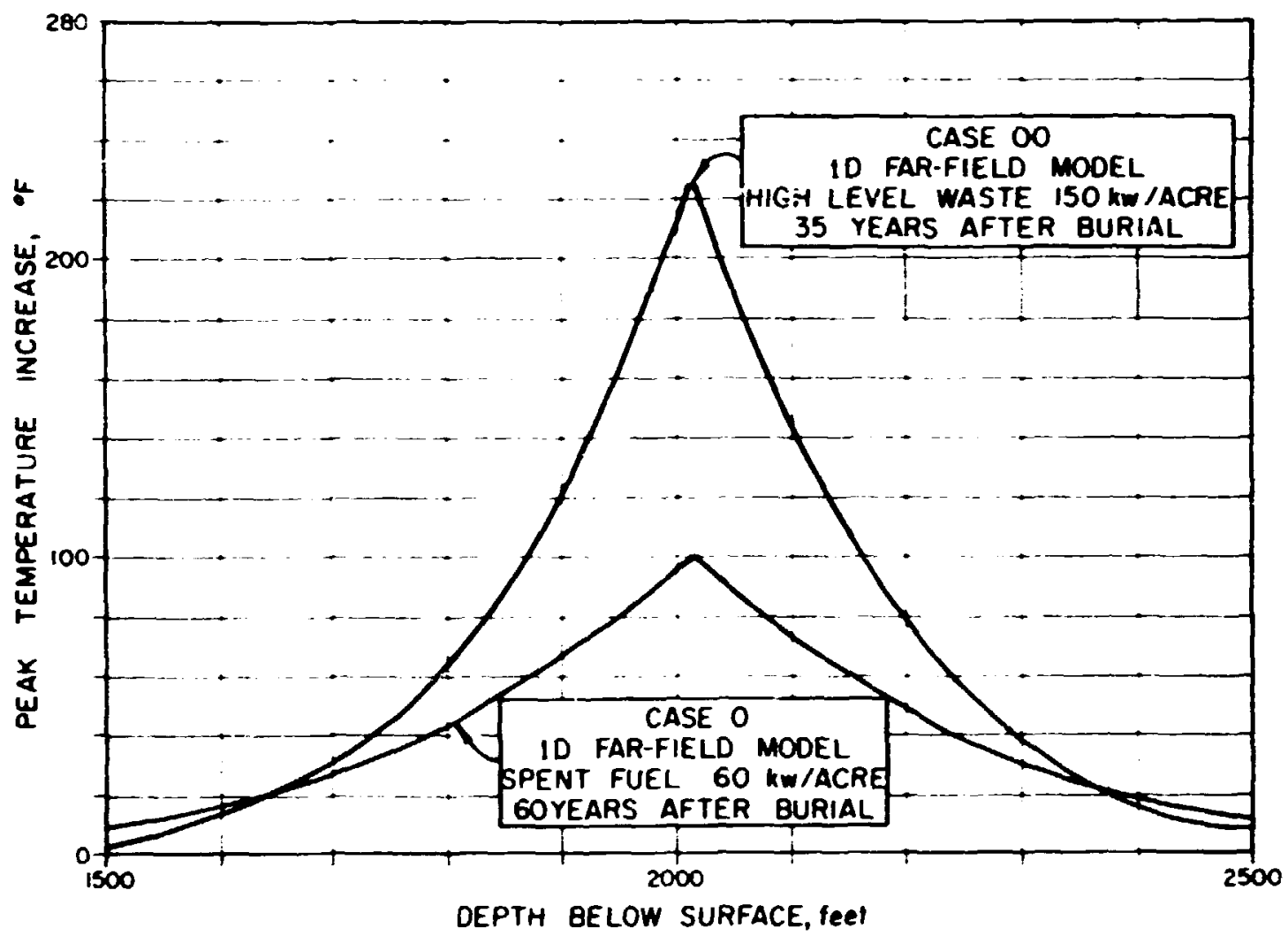

Fig. 8.1. Peak temperature increases in one-dimensional salt models as functions of depth for SF stored at $60 \mathrm{~kW} / \mathrm{acre}$ and HLW stored at $150 \mathrm{~kW} /$ acre.

The two-dimensional far-field model containing SF for case 1 is shown in Fig. 8.2. The 133-Mh source in this model is a right circular cylinder that is $12 \mathrm{ft}$ in height, has a radius of $5544 \mathrm{ft}$, and has an injtial volumetric heat generation of $3432 \mathrm{Btu} / \mathrm{yr} \cdot \mathrm{ft}^{3}$. The heat source extends frc 7 a depth of $2010 \mathrm{ft}$ to a depth of $2022 \mathrm{ft}$. The repository area containing the SF is about 2217 acres, based on a total heat load of $133 \mathrm{MW}$ stored at $60 \mathrm{~kW} / a c r e$. This model has an adiabatic boundary at a radius of $24,000 \mathrm{ft}$.

A similar far-fteld model loaded with $\mathrm{HLW}$ at $150 \mathrm{~kW} / \mathrm{acre}$ is used for case 2 as shown in Fig. 8.3. This model has the same boundary conditions as described for case 1 except that the adiabatic radial boundary is imposed at a radius of $15,000 \mathrm{ft}$. The repostory area in this case is 883 acres, based on a total heat load of $133 \mathrm{MW}$ stored at $150 \mathrm{~kW} / \mathrm{acre}$. 


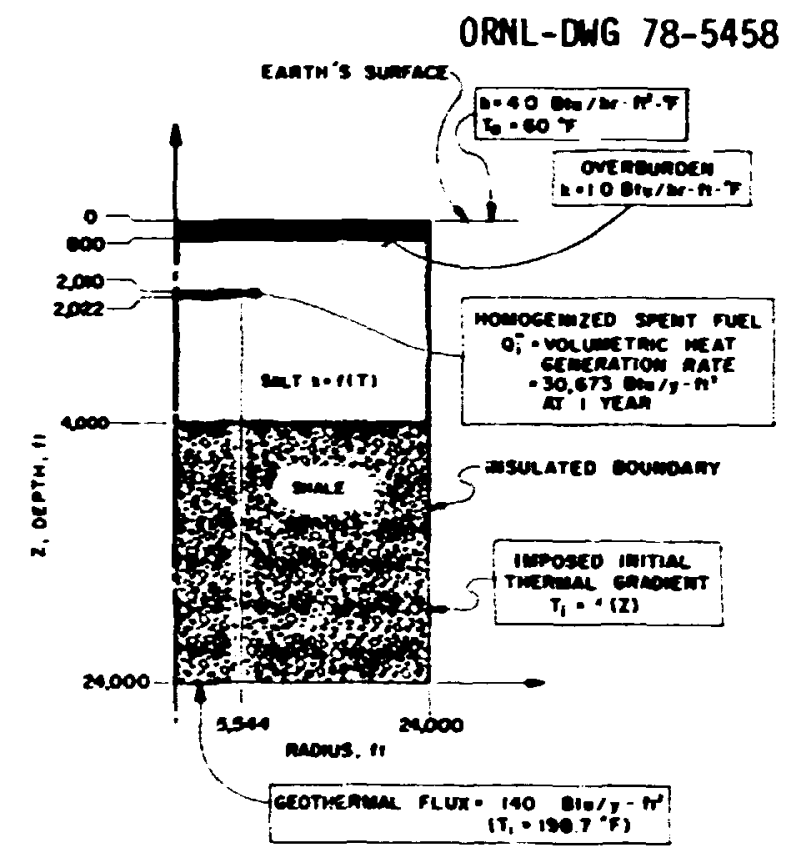

Fig. 8.2. Two-dimensional homogenized far-field heat transfer model of a 2217-acre SF repository.

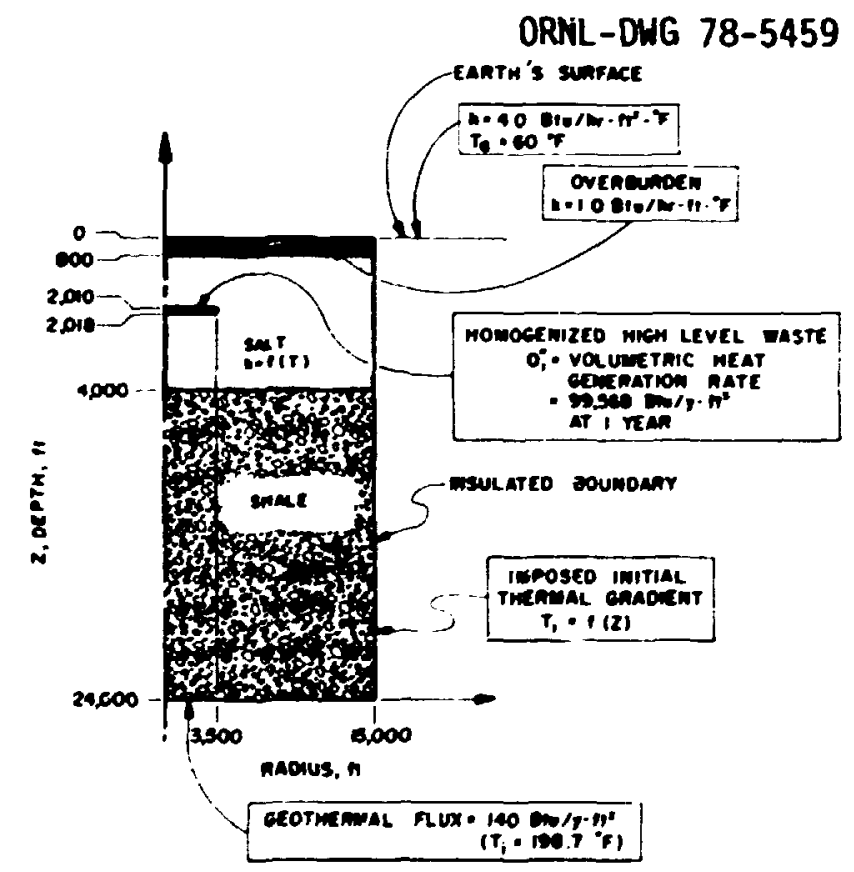

Fig. 8.3. Two-dimensional homogenized far-field heat transfer model of an 883-acre HLW repository. 
The source in this model is bounded at a radius of $3500 \mathrm{ft}$ and extends from a depth of $2010 \mathrm{ft}$ to a depth of $2018 \mathrm{f}:$. The initial volumetric heat generation of the source is $12,916 \mathrm{Btu} / \mathrm{yr} \cdot \mathrm{ft}^{3}$.

Temperature increases ( $\Delta T s$ ) as functions of depth below the earth's surface for times up to 30,000 years have been determined for the storage of SF loaded at $60 \mathrm{~kW} / \mathrm{acre}$ (case 1) as shown in Fig. 8.4. Similar distributions have been obtained for HLW loaded at $150 \mathrm{~kW} /$ acre (case 2) as shown in Fig. 8.5. On comparison, it is apparent that initially the HLW produces much higher temperature increases, but after about 300 years, the $\Delta T s$ in the HLW repository are much lower than in the SF repository. Note also that the resulting temperature distribution is not quite symmetric. Points above the source are cooler than below it in both the SF and HLW cases because of the cooling effect of the atmosphere. A peak temperature of $100^{\circ} \mathrm{F}$ was obtained for SF 60 years after burial, whereas a peak tempera-ture increase of $223^{\circ} \mathrm{F}$ was obtained for HLW 35 years after burial. The temperature distributions in $Z$ direction are practically identical with those obtained from the one-dimensional analysis. Because the one-dimensional cases are much simpler and cheaper to run, they can be used instead of two-dimensional models whenever temperature distribution as a function of depth is the only interest.

Figure 8.6 shows the temperature increases at the edge of the repository containing SF loadec at $60 \mathrm{~kW} /$ acre as a function of the radial distance from the centerline for various times up to 30,000 years. Figure 8.7 shows the same relationships at the edge of a repository containing HLW loaded at $150 \mathrm{kw} / a c r e$. It is quite apparent from comparison of these two figu es that the temperature increase incurred by the SF exceeds that incurred by the HLW after 500 years. In both cases, the $\Delta T$ at the resository midplane remains quite flat over most of the repository area, wiich indicates little radial heat transfer near the center of the reposicory. At a radial distance of about $600 \mathrm{ft}$ from the repository containing $\mathrm{SF}$, a midplane $\Delta T$ of no more than $15^{\circ} \mathrm{F}$ is noted at any point in time. A similar observation is made for the case of the HLW. Here the $\Delta T$ is less than $10^{\circ} \mathrm{F}$ within $500 \mathrm{ft}$ of the repository edge. This observation is very important because 1 t reinforces the assumption of adiabatic radial boundary conditions on the unit-cell models. 
ORNL-DNG $78-5460$

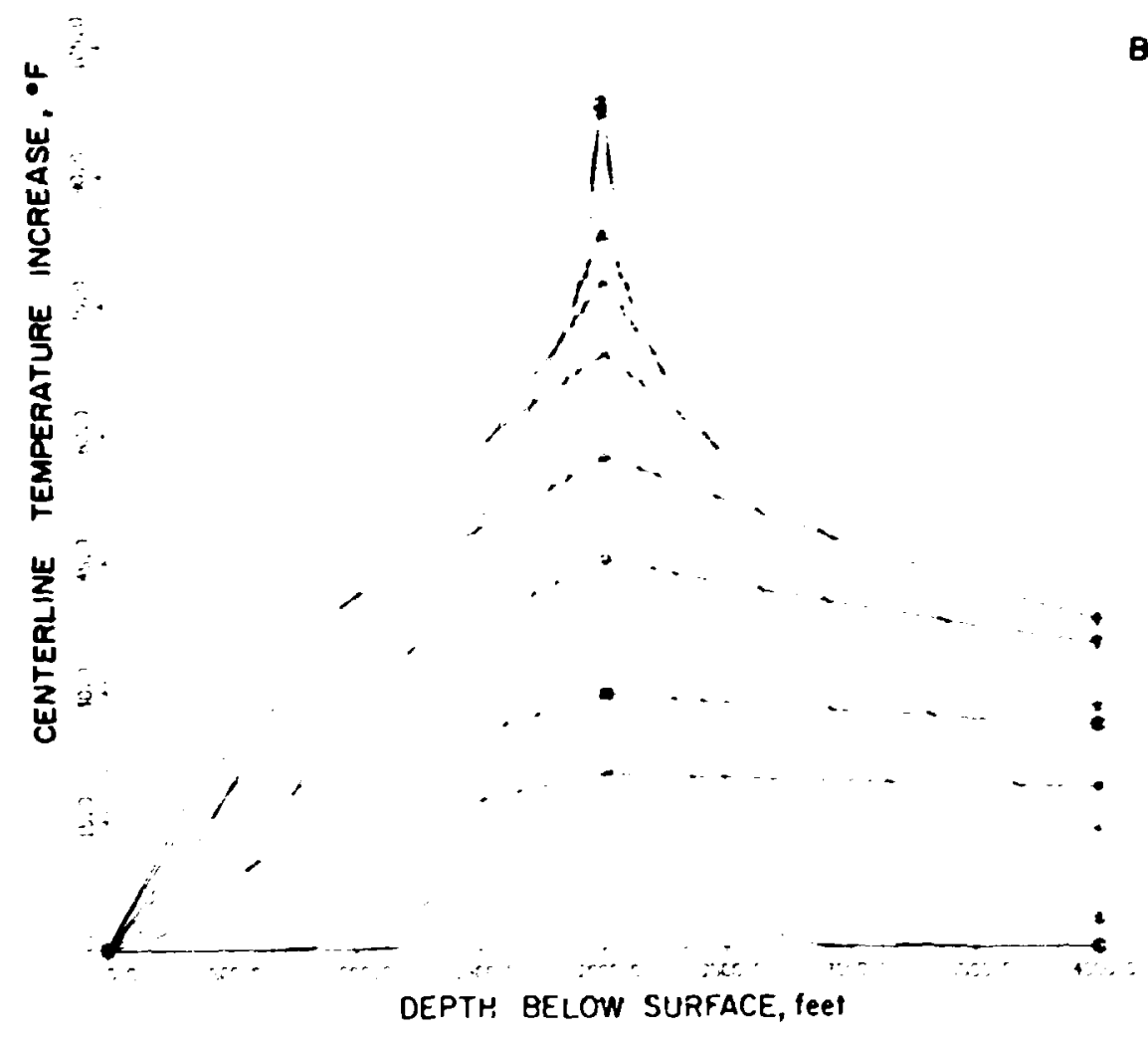

BURIAL TIME, yeors

Fig. 8.4. Centerline temperature increase in a two-dimensional farfield model at various imes as functions of depth resulting from the storage of SF at $60 \mathrm{~kW} / a c r e$.

Figure 8.8 shows the $C T$ at various depths along the centerline of a repository loaded with $S F$ at $60 \mathrm{~kW} / \mathrm{arre}$ as functions of time. Figure 8.9 shows the same profiles for HLW loaded at $150 \mathrm{~kW} /$ acre. The same information is shown in these plots as was presented in Figs. 8.4 and 8.5, but the emphasis is on behavior of temperature with respect to time.

At a depth below about $1500 \mathrm{ft}$, the $\Delta T S$ in the HLW repository are greater than or equal to the $\Delta T$ obtained from the SF repository, but at leptrs less than $1500 \mathrm{ft}$ the $\Delta \mathrm{TS}$ in the HLW repository are less than those found in the reposicory containing the SF. At peaking time (35 years after burfal) the $\Delta T$ in the HLW is about 2.3 times that found in the SF, but at about 300 years after burial they are about the same $\left(85^{\circ} \mathrm{F}\right)$, and at longer times the $\Delta T$ Ts are greater in the SF repository than in the HLW repository. 
ORNL-OWG 78-5461

(n)

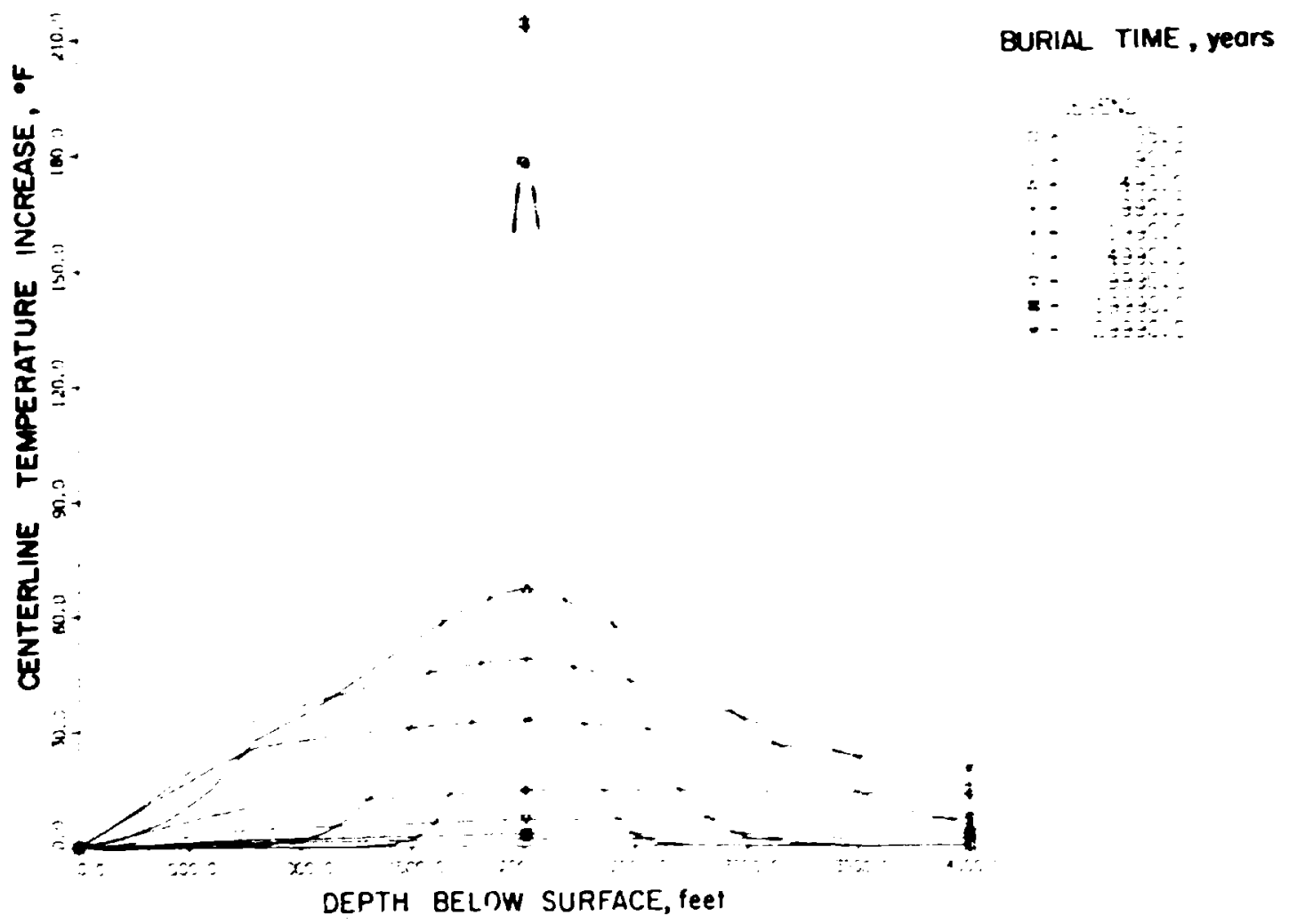

Fig. 8.5. Centerline temperature increase in salt in two-dimensional far-field model at various times as function of depth resulting from the storage of $\mathrm{HLW}$ at $150 \mathrm{~kW} / \mathrm{acre}$.

Figure 8.10 shows the midplare temperature increases incurred from the storage of $\mathrm{SF}$ at $60 \mathrm{~kW} / \mathrm{acre}$ as functions of time at various radial locations. Similar profiles have been obtainef for HLW stored a: $150 \mathrm{~kb} / \mathrm{acre}$ and are shown in Fig. 8.11. These plots present the same information as Figs. 8.6 and 8.7, in which the main interest was on the temferature distribution at the edge of the repository. Here, the emphasis is on the variation of the temperature increase with time at a particular location. The main differences observed between the SF and the HLW is that the HLW peaks more quickly with a higher temperature increase and returns more quickly to the initial conditions. The $\mathrm{ST}$ in the SF repository peaks more slowly and holds close to the peak for a longer period than the HLW. Both curves have a noticeable drop in the temperature increase at the edge of the repository. 
ORNL-OWG 78-5462

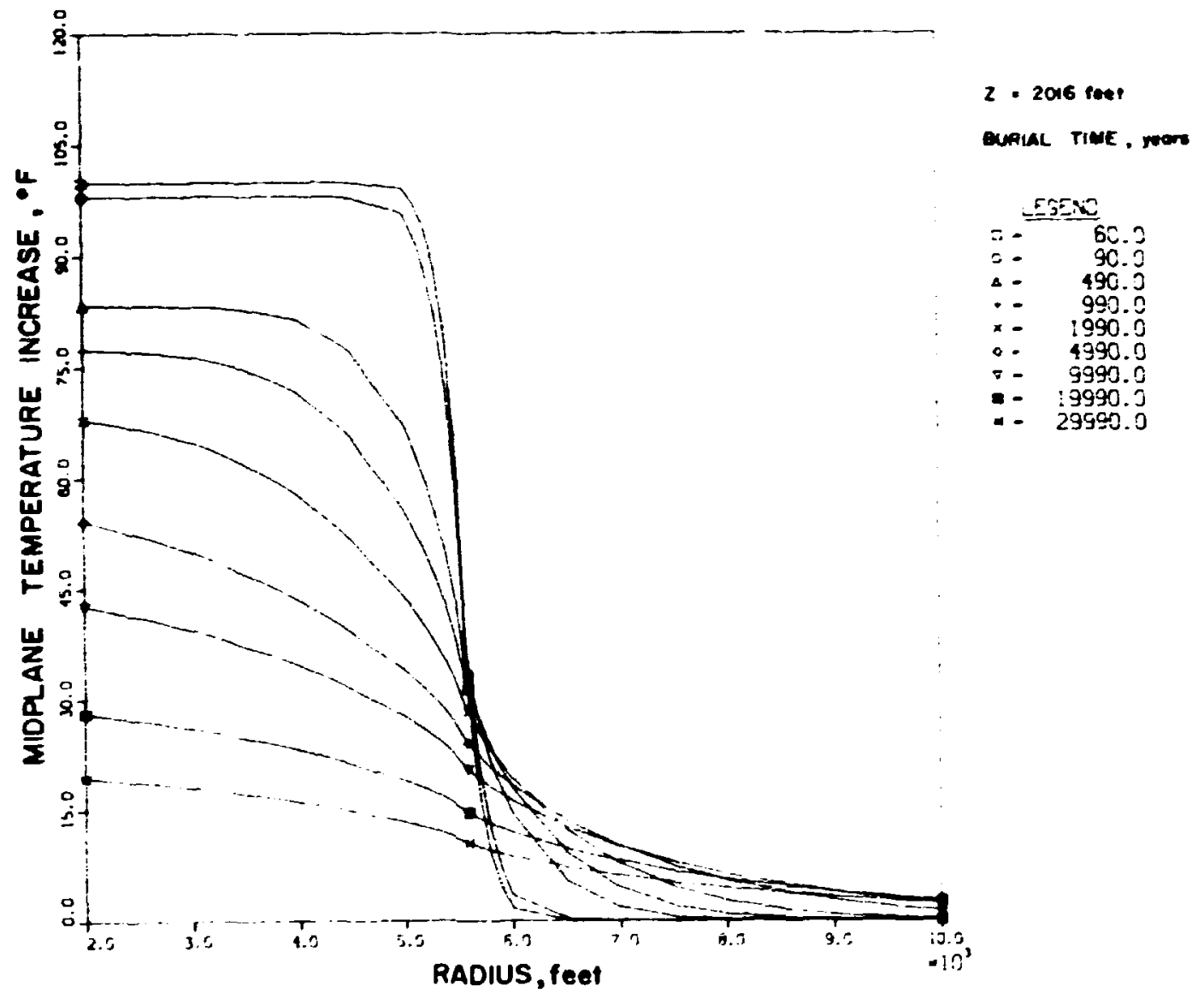

Fig. 8.6. Midplane temperature increases in salt at various times as functions of radial distance from the centerline in a repository loaded with SF at $60 \mathrm{k}$ / $/$ acre.

\subsection{Two-Dimensional Unit-Cell Models (Cases 3 and 4) and liumerical Results}

The two-dimensional unit-cell models were created to obtain the maximum near-field temperatures. These models extend from the surface of the earth to a depth of $4000 \mathrm{ft}$. The 4000- $\mathrm{ft}$ depth was chosen because in a 200-year transient, heat is not propagated in sufficient quantity to cause appreclable temperature changes at the boundaries.

Figure 8.12 shows the two-dimensional unit-cell model. for a PWK spent fuel assembly as used for case 3. The heat source used in this model is emplaced as was 1llustrated in Fig. 4.1 with a volumetric heat generation of $6.27 \times 10^{5} \mathrm{Btu} / \mathrm{yr} \cdot \mathrm{ft}^{3}, 10$ years after removal from the reactor as discussed in Sect. 4.3. 


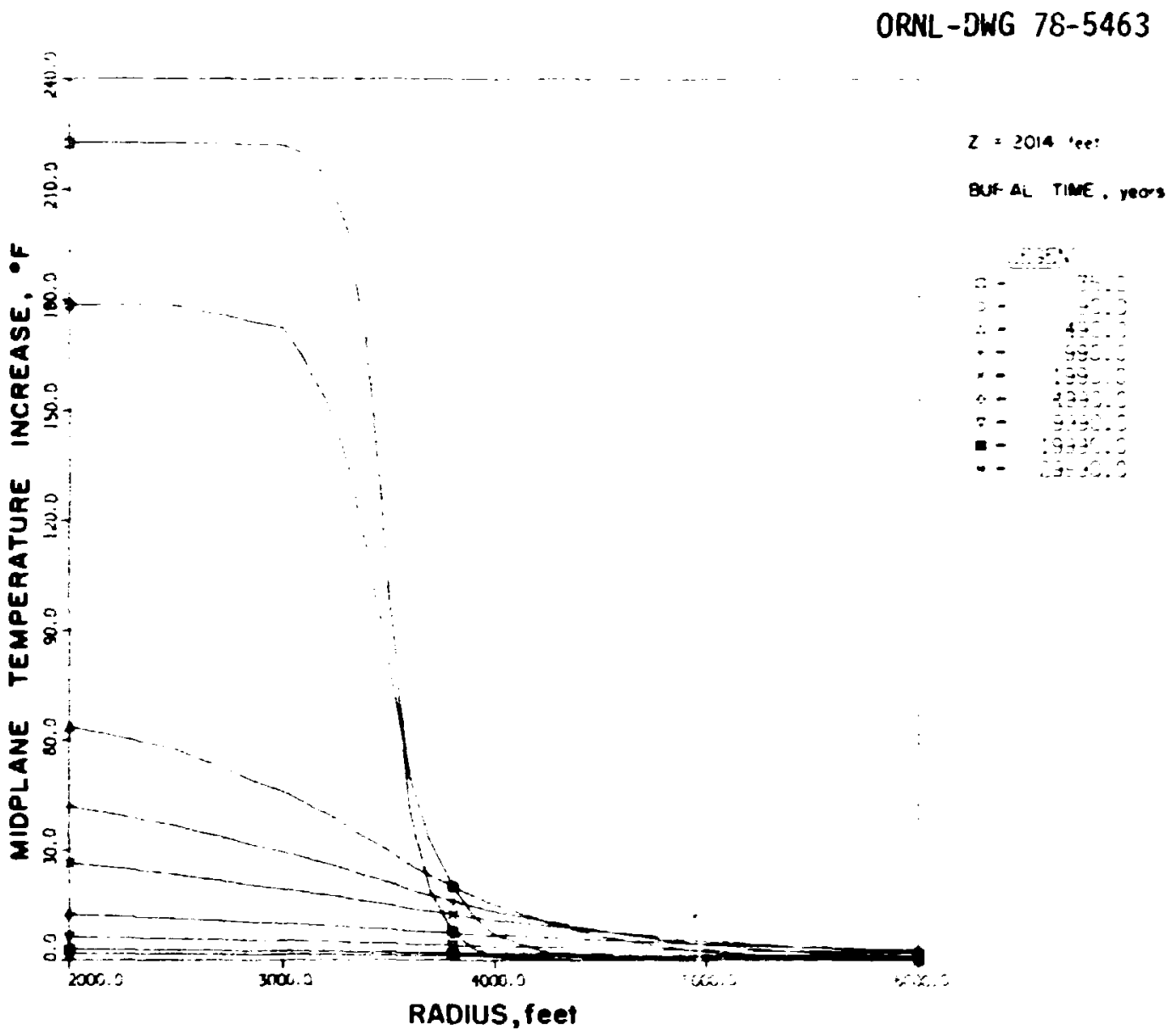

Fig. 8.7. Midplane temperature increases in salt at various times as functions of radial distances from the centerline in a reposi ory lraded with $\mathrm{HLW}$ at $150 \mathrm{~kW} / \mathrm{acre}$.

The pro rata area of the $60-\mathrm{kW} /$ acre SF repository associated with one fuel assembly generating $0.55 \mathrm{~kW}$ f.s 0.0092 acres $\left(399 \mathrm{ft}^{2}\right.$ ), which res $\mathrm{lts}$ In a unit-cell radius of $11.26 \mathrm{ft}$. The source has a radius $0: 0.83 \mathrm{ft}$ and is located between a depth of 2010 and $2022 \mathrm{ft}$ as previously described.

A similar model for use with case 4 was formulated for HLW and is shown in Fig. 8.13. The heat source used in the model has a $0.83-\mathrm{ft}$ radius and extends from a depth of $2010 \mathrm{ft}$ to a depth of $2018 \mathrm{ft}$; it has a volumetric heat gejeration of $3.60 \times 1.0^{6} \mathrm{Btu} / \mathrm{yr} \cdot \mathrm{ft}^{3} 10$ years after reprocessing.

The pro rata area of the $150-\mathrm{kW} / \mathrm{acre}$ HLW repository associated with one canister generating $2.1 \mathrm{~kW}$ is 0.014 acres $\left(610 \mathrm{ft}^{2}\right)$, whtch results in a unte-cell radius of $13.92 \mathrm{ft}$. 
ORNL-DWG 78-5464

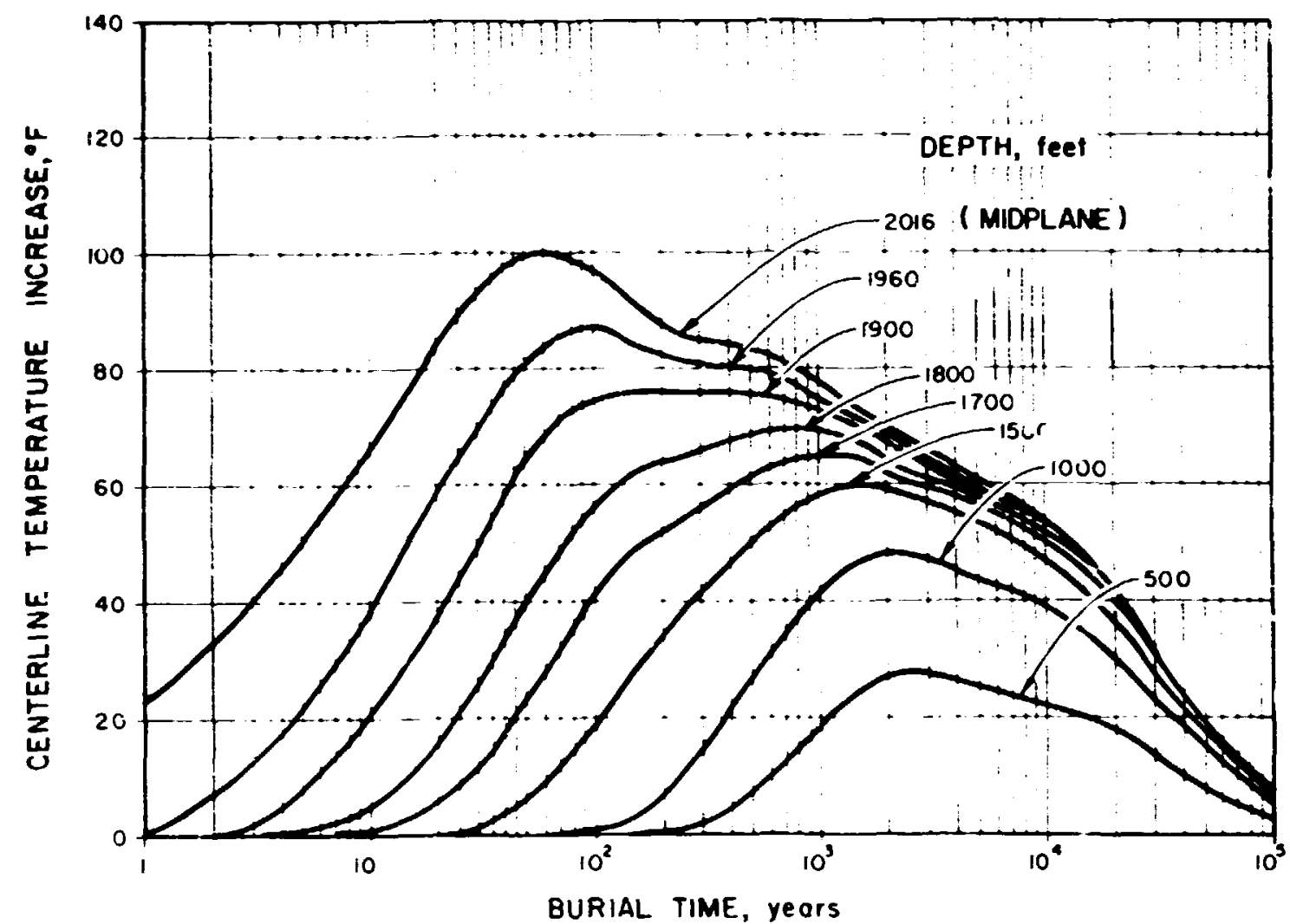

Fig. 8.8. Centerline temperature increase in salt in a two-dimensional far-field model at various depths as functions of zime resulting from the storage of SF at $60 \mathrm{~kW} / \mathrm{acre}$.

The pertinent information to be obtained from these models is the maximum temperature increase $(\Delta T)$, its location, and its peaking time. As shown in Fig. 8.14, a peak maximum $\Delta \mathrm{T}$ of $105^{\circ} \mathrm{F}$ was calculated for the salt about 50 years after burial in the case of SF. This maximum temperature occurs on the canister surface at a deptil of $2016 \mathrm{ft}$. A simflar peak maximum $\Delta T$ of $269^{\circ} \mathrm{F}$ was calcuiated for HLW at a depth of $2014 \mathrm{ft}$ about 25 years after burial.

\subsection{Three-Dimenstonal Models (Cases 5 and 6) and Numerical Results}

The three-dimenstonal unit-cell wodel with no air exchange in an open room appears to be the most conservative of any of the models attempted. The three-dimensional model is designed to simulate a cell of an open room 
ORNL-DWG 78-5431

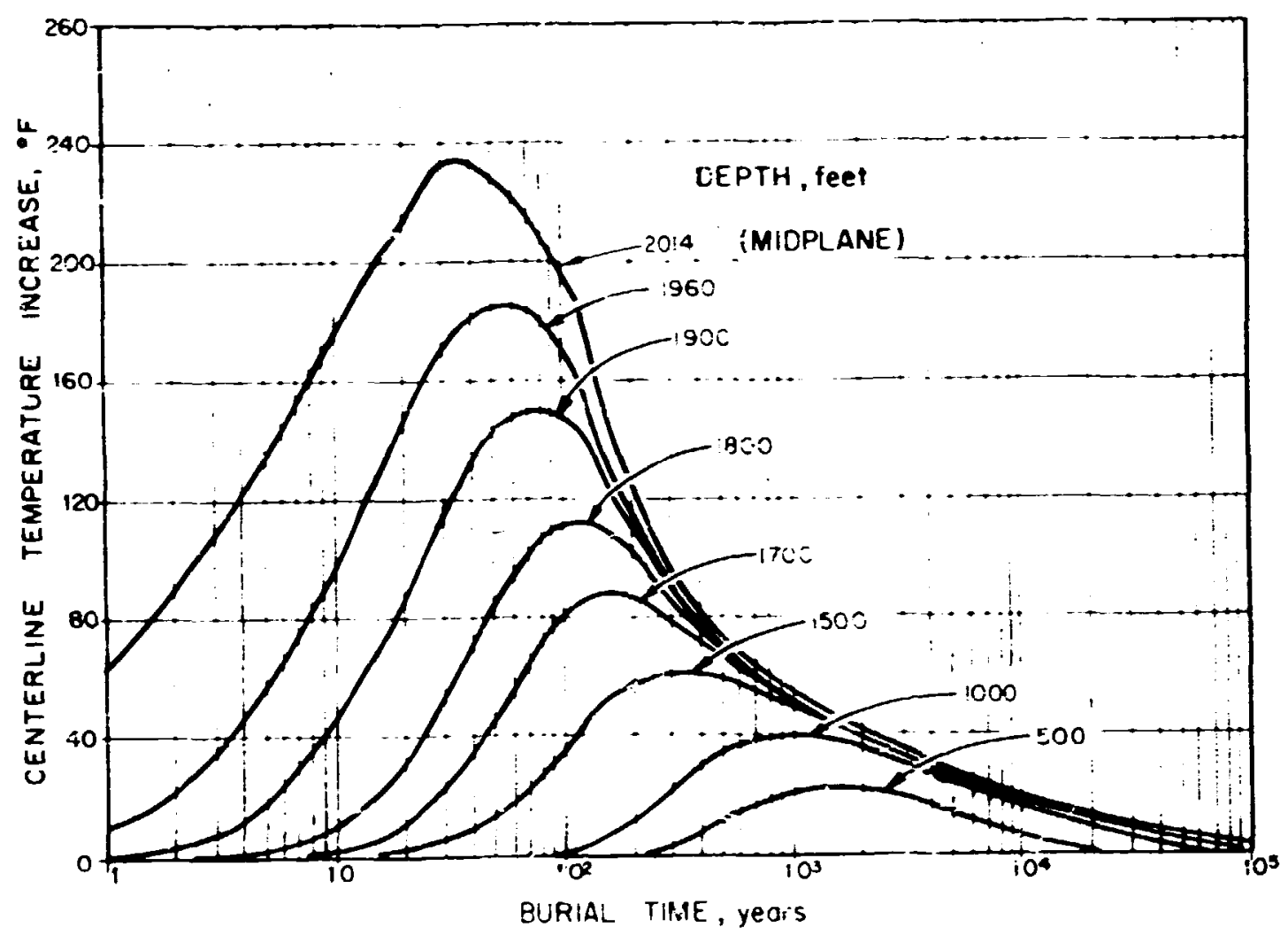

Fig. 8.9. Centerline cemperature irrereases in salt in a two-dimensional far-field modei at various depths as functions of rime resulting from the storage of $\mathrm{HLW}$ at $15 \mathrm{C} \mathrm{kN} / \mathrm{acre}$.

in $\exists$ repository. The boundary condtion; imposed on the surfaces of the room are quite important in predicting the temperatures in the salt, and several factors must be considered.

If forced air circulation is assumed, the maximum surface temperature could eventually be reduced close to the temperature of the bulk air, but flow requirements would be excessively large to arcompiish this purpose. If each cell is assumed isolated, or sealed, the air eventually will assume the mean temperature of the room with only minor heat transfer due to natural convection. Therefore, a sealed room was modeled and the convection losses were conservatively neglected; only heat transfer by radiation from the wermer floor to the cooler ceiling was considered. The emissivities of both $s: r f a c e s$ were assumed to be 0.8 (dimensionless). The retrievable mode of operation is where the room is not backfilled, although it can be sealed, with the waste materi:l being accessible. The SF is burfed so that 


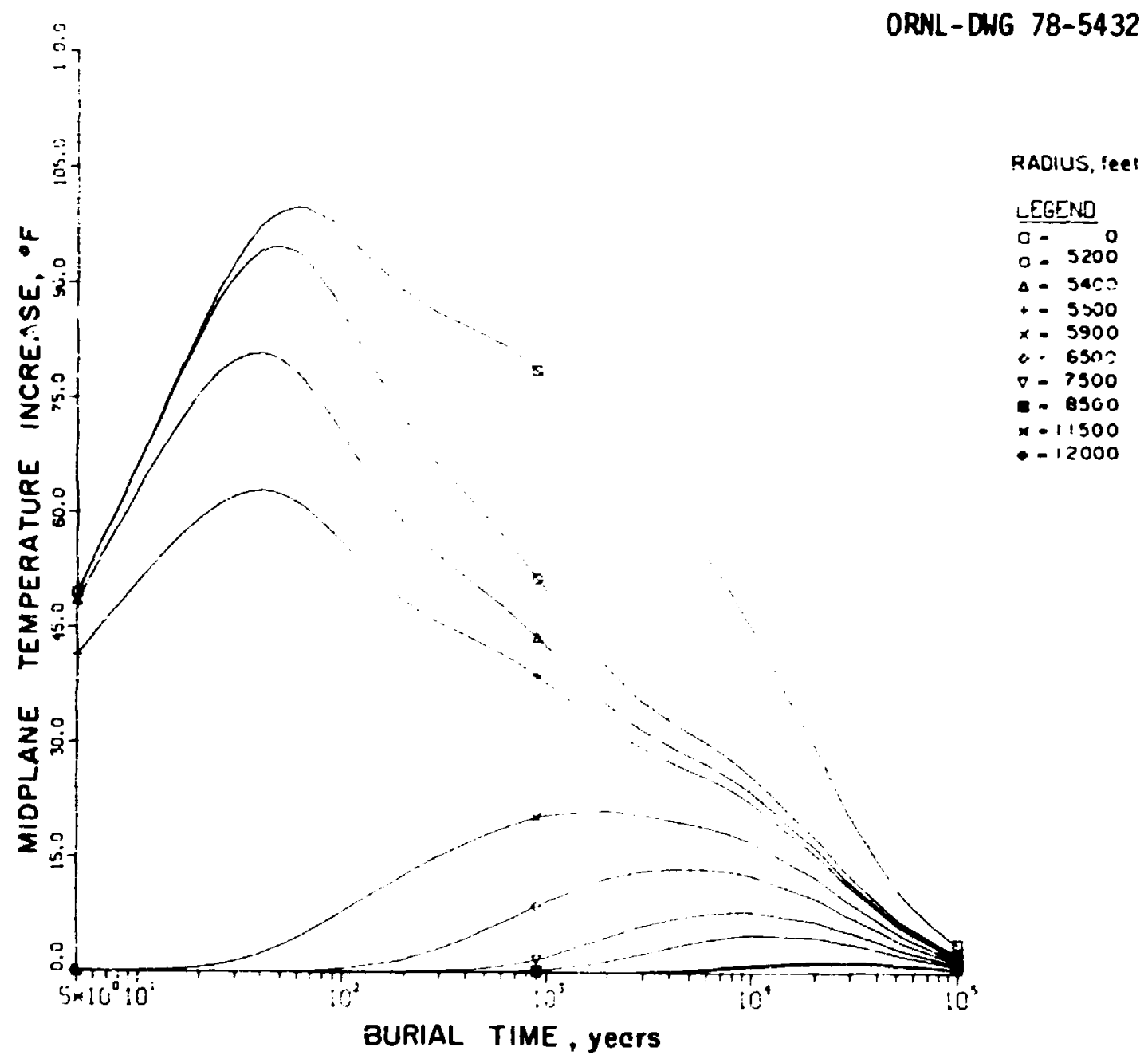

Fig. 8.10. Midplane temperature increases at various radial locations as functions of time in a repository loaded with $\mathrm{SF}$ stored at $150 \mathrm{~kW} / \mathrm{acre}$.

it can be retrieved for up to 25 years, whereas the period of retrievability for the HLW is 5 years. Due to these considerations, the transients for both three-dimensional models were extended to 35 years.

The three-dimensional model is shown in F:g. 8.15. Iu order to conserve nodes, the vertical boundaries were confined to within $600 \mathrm{ft}$ of the source. Basad on results achieved in the one-dimenstonal models, a boundaxy temperature of $75.8^{\circ} \mathrm{F}$ was placed on the upper bourdary at a depth of $1400 \mathrm{ft}$, and a constant temperature of $81.8^{\circ} \mathrm{F}$ was 1 mpcised at the lowest bounciay along with the geothermal flux at a depth of $2600 \mathrm{ft}$. This threedimensional model is based on a rectangular layout of 60-ft p1llars and 
ORNL-DWG 78-5433

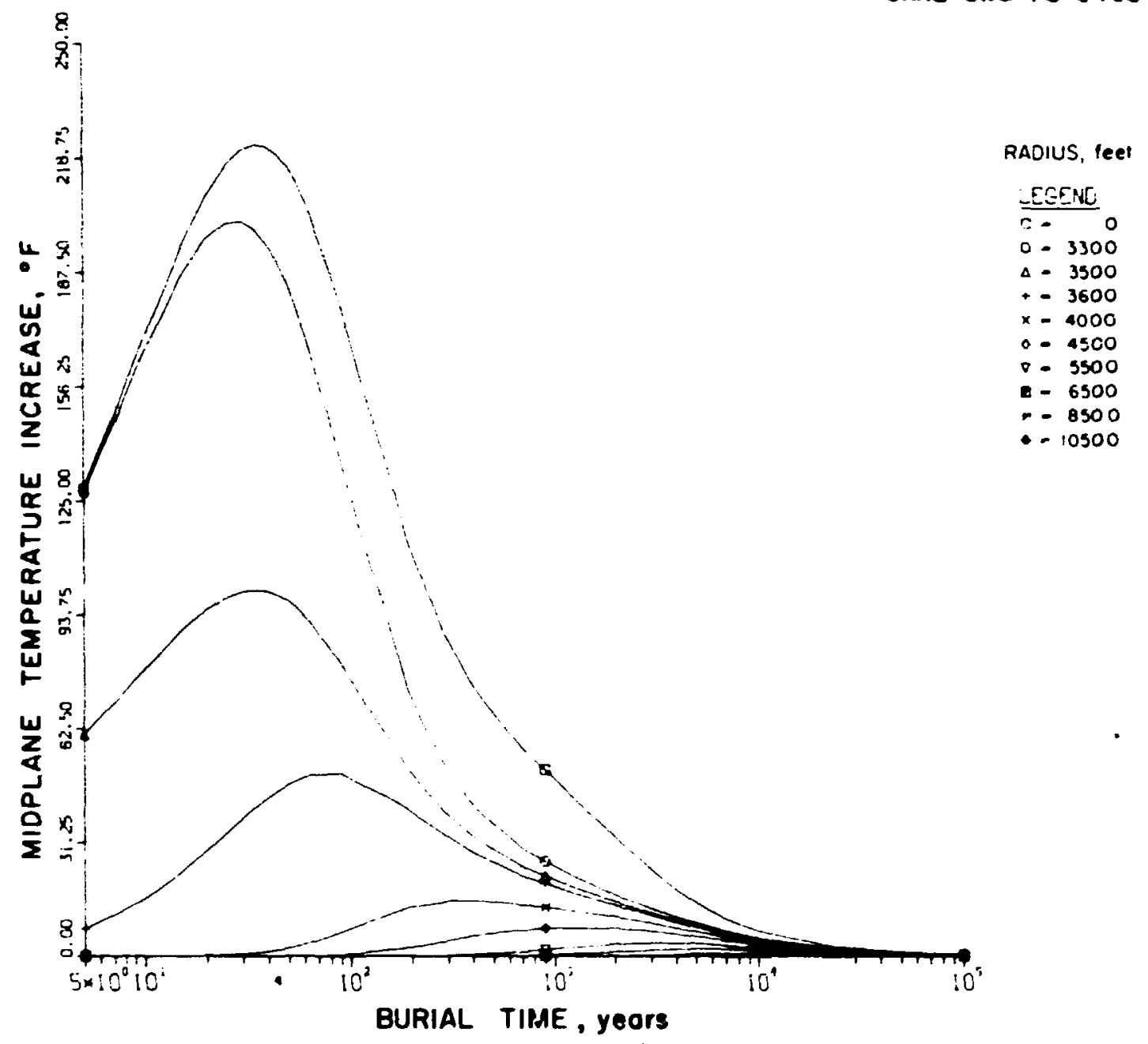

Fig. 8.11. Midplane temperature increases at varlous radial locations as functions of time in a repository loaded with HLW stored at $60 \mathrm{~kW} / \mathrm{acre}$.

rooms that are $18 \mathrm{ft}$ wide and $18 \mathrm{ft}$ high. The rooms and the canister centerlines are spaced $78 \mathrm{ft}$ on center. Based on the ar $3 a l$ heat production of 60 and $150 \mathrm{~kW} / \mathrm{acre}$, the calculated pitch between the canisters along each room for the $S F$ is $5.12 \mathrm{ft}$ and $7.82 \mathrm{ft}$ for the HLW respecilvely. Half pitches are used in the three-dimenstonal models to make use of symetry 11nes. The heat generation rates are the same as calculated for cases 3 and 4. The only difference is the configuration $s i$ the heat sources, which are square rather than round. Note that the salt areas in the two-dimensional unit-cell models ssociated with a single canister are identical to the areas in the three-dimensional models. 


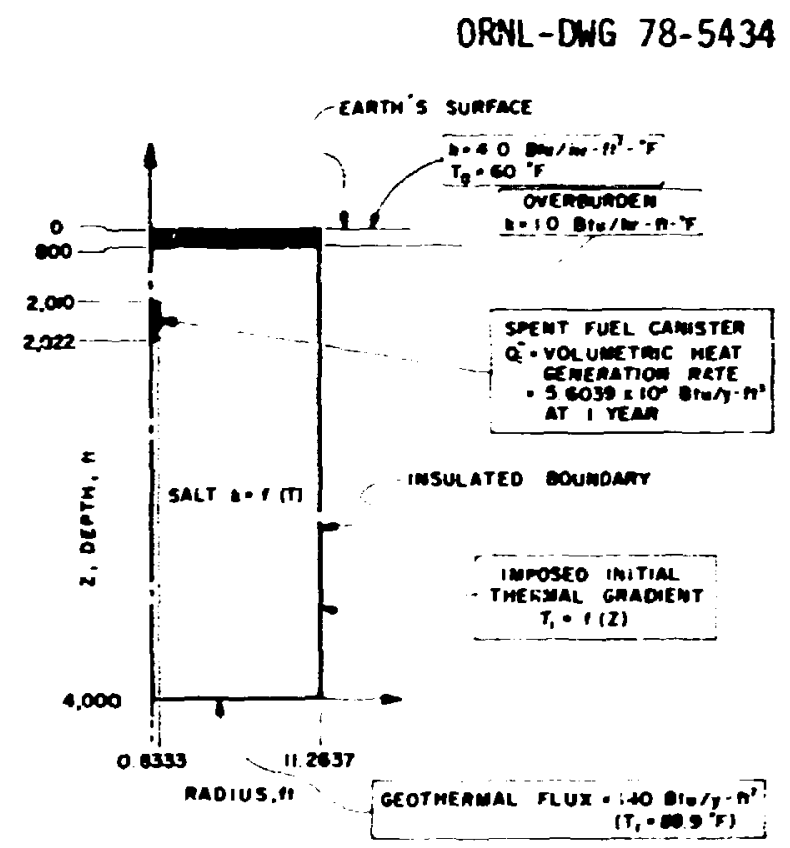

Fig. 8.12. Two-dimensional unit-cell model for storage of a cantster containing a spent fuel assembly.

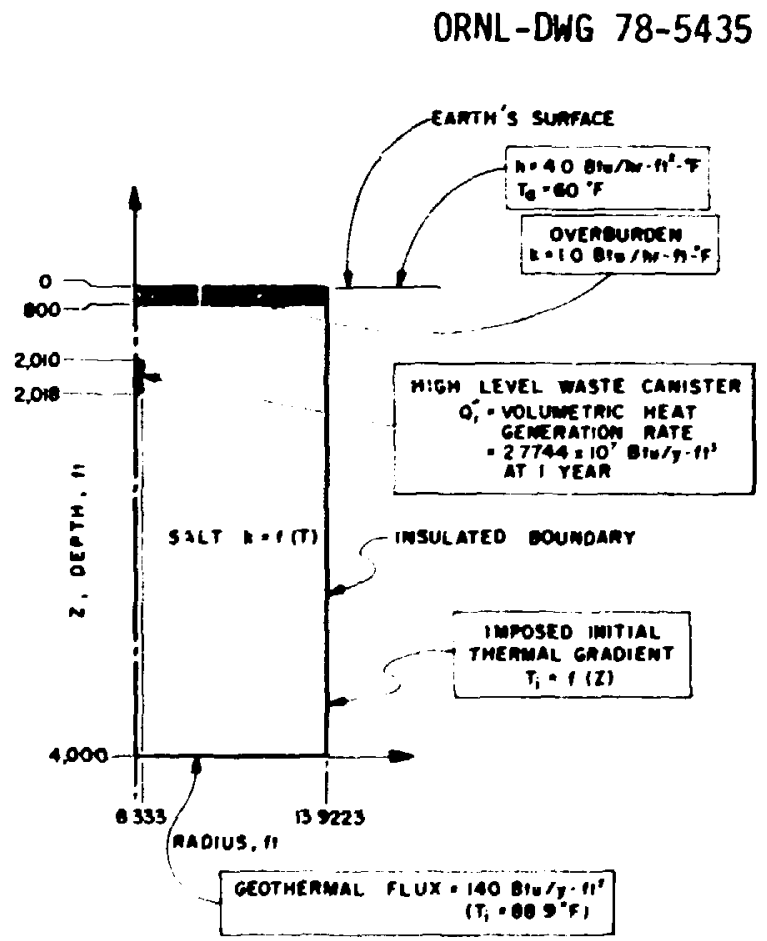

Fig. 8.13. Two-dimensional unit-cell model for storage of a canister of HLW. 
ORNL-DWG $78-5436$

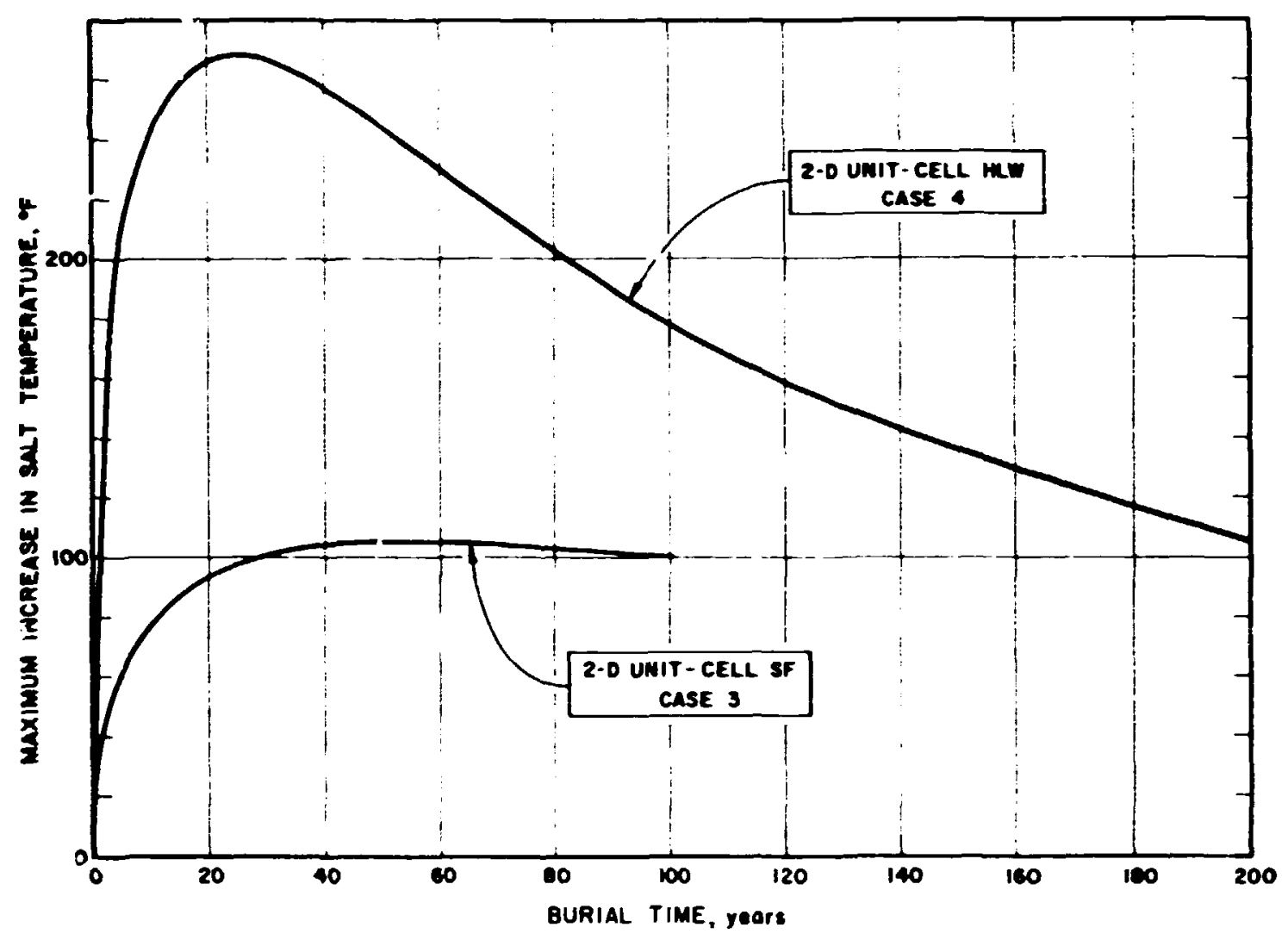

Fig. 8.14. Comparison of maxirum temperature increases as functions of time in the two-dimensional unit-cell models for SF stored at $60 \mathrm{kH} / \mathrm{acte}$ and HLW stored at $150 \mathrm{~kW} / a c r e$.

A 35-year transient was run on the three-dimensional models for cases 5 and 6 . The maximum increase in the salt temperature $(\Delta T)$ for both of these cases is plotted in Fig. 8.16. The peak maximum $\Delta \mathrm{T}$ of $113^{\circ} \mathrm{F}$ is obtained in case 5 for SF and occurs 35 years after burial. In case 6 , the peak maximum $\Delta \mathrm{T}$ of $301^{\circ} \mathrm{F}$ is obtained for $H L N 20$ years after burial. These peak maximum $\Delta T$ s occur on the surface of the canister at the repository midplane.

The maximum $\Delta T$ encountered for the $S F$ in the salt after 25 years (the proposed backfilling time of the $100 \mathrm{~m}$ for $\mathrm{SF}$ ) is about $110^{\circ} \mathrm{F}$, which is equivalent to a maximum temperature of $189^{\circ} \mathrm{F}$. The maximum $\Delta \mathrm{T}$ encountered for the HLW in the salt after 5 years (the proposed backfiling time for HLW) is about $260^{\circ} \mathrm{F}$, which is equivalent to a maximum temperature of $339^{\circ} \mathrm{F}$. Another point of interest in the three-dimensional analysis is the maximum accessible room temperature, which occurs on the floor directly 


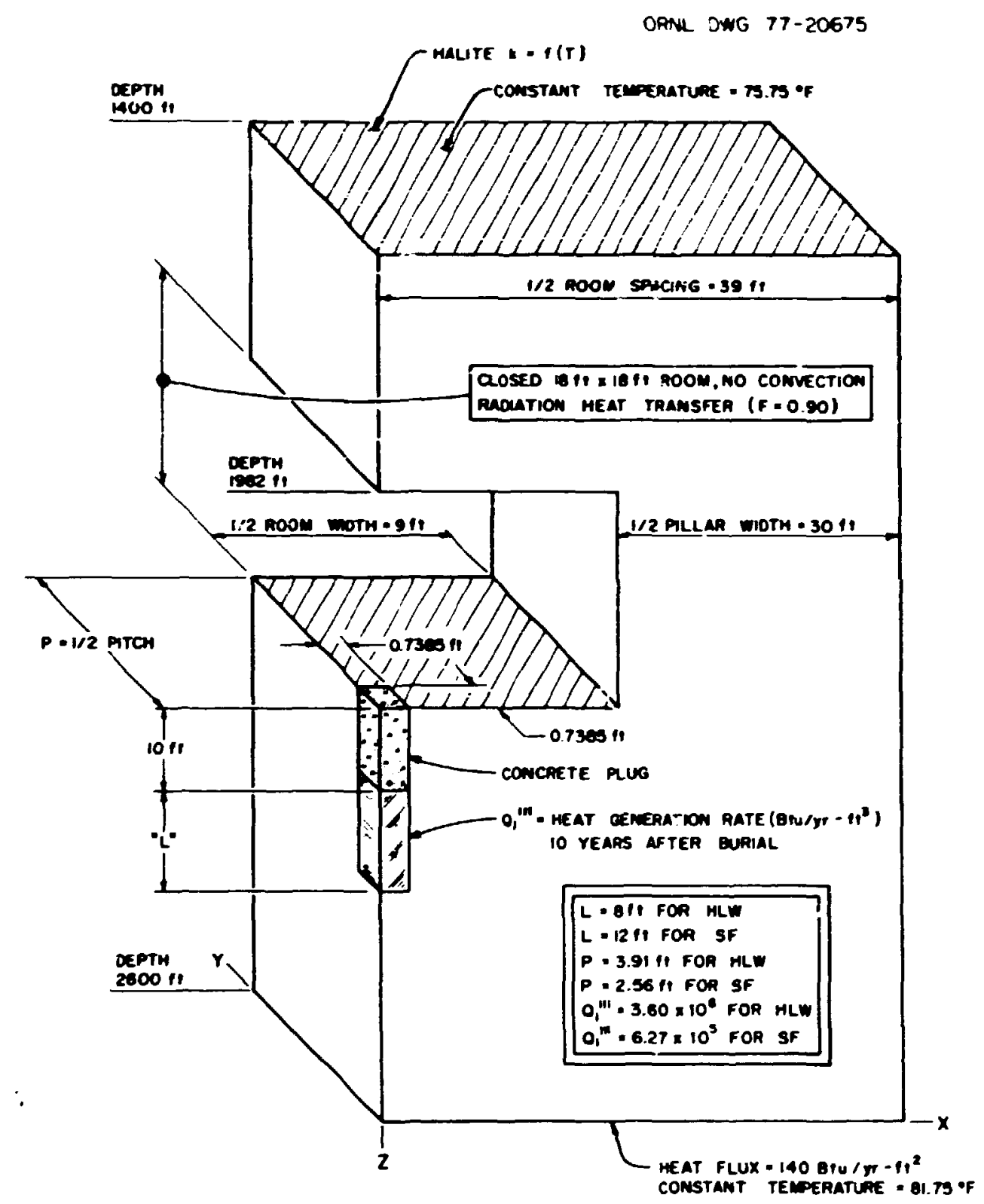

Fig. 8.15. Three-dimensional unit-cell model for a PWR spent fuel assembly or high-level waste canister.

over the waste canisters. Figure 8.17 shows the maximum floor temperature as a function of time for SF in case 5 and for HLW in case 6 .

The maximum temperature obtained on the floor of the room containing HLW at the time of backfliling ( 5 years) is about $191^{\circ} \mathrm{F}$. A peak maximum floor temperature of $294^{\circ} \mathrm{F}$ occurs for HLW after 35 years, or 30 years after the planned backfilling time. Rooms used to store HLW are not expected to remain open for more than 5 years. 
ORNL-DNG 78-5438

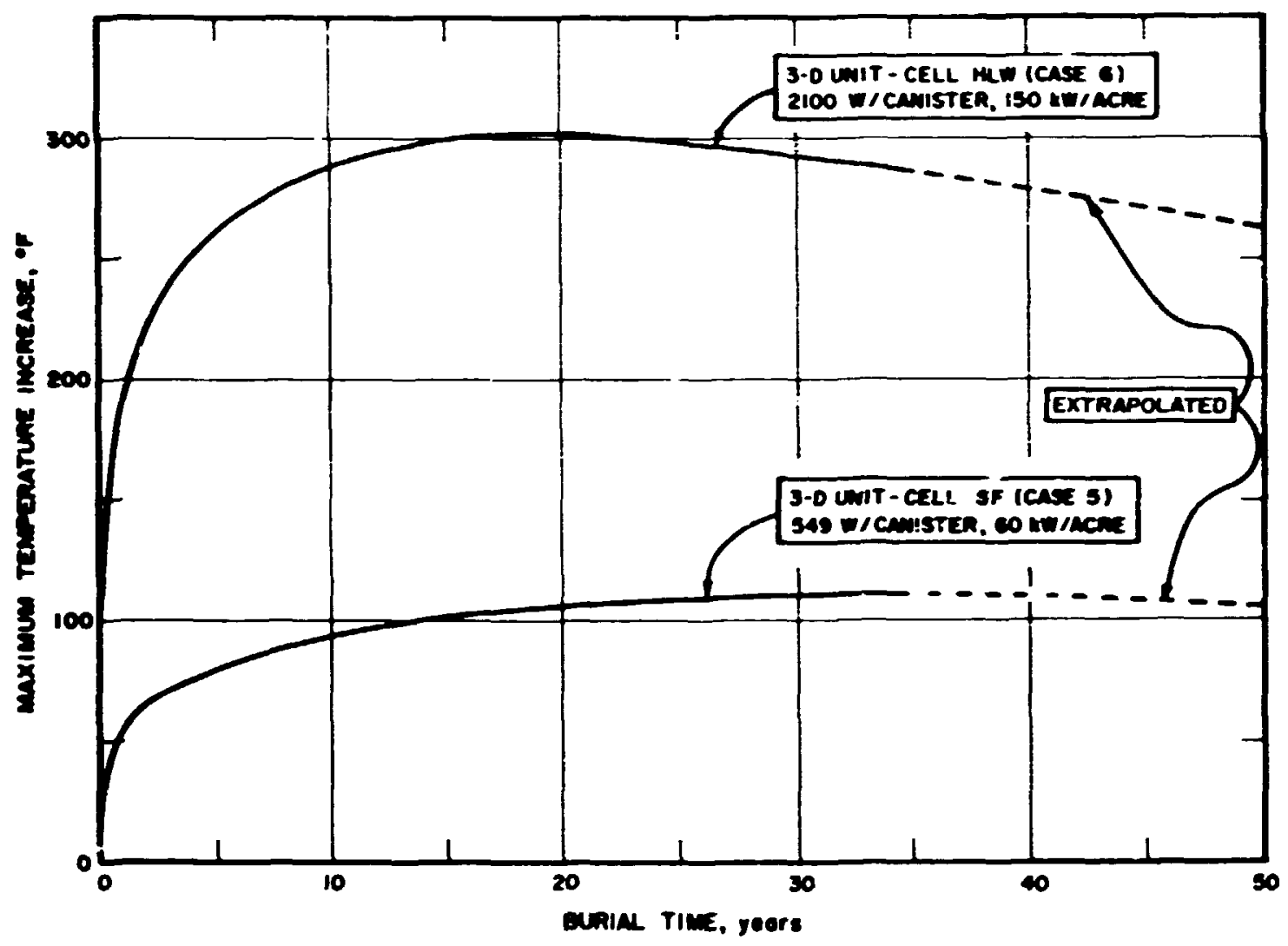

F18. 8.16. Comparison of maximum temperature increases in salt as functions of time in the three-dimensional unit-cell models for SF stored at $60 \mathrm{kH} / \mathrm{acre}$ and $\mathrm{HLH}$ stored at $150 \mathrm{kH} / \mathrm{acre}$.

A similar maximum temperature on the floor of the room conraining SF at the time of backfilling ( 25 years) is about $161^{\circ} \mathrm{F}$. A peak maximum temperature found for the floor of the room in case 5 is about $169^{\circ} \mathrm{F}$, which occurs 10 years after the planned backfilling time.

In order to simulate backfiling, it would ve necessary to input the temperature distribution obtained in the open room at the time of backfilling and instantaneously fill the room with crushed salt at a given temperature. All thermal properties would have to be programed as functlons of tiwe and the thereal conductivity expressed as functions of both time and temperature to allow for the process of reconsoildation of the crushed salt. No backfilling has been assumed in the present three-dimenslonal models.

Contours of constant $\Delta T$ s (called 1sotherms here for simplicity) were generated ut1lizing the HEATPLOT ${ }^{30}$ computor code for cases 5 and 6 at 
ONNL-DWG 78-5439

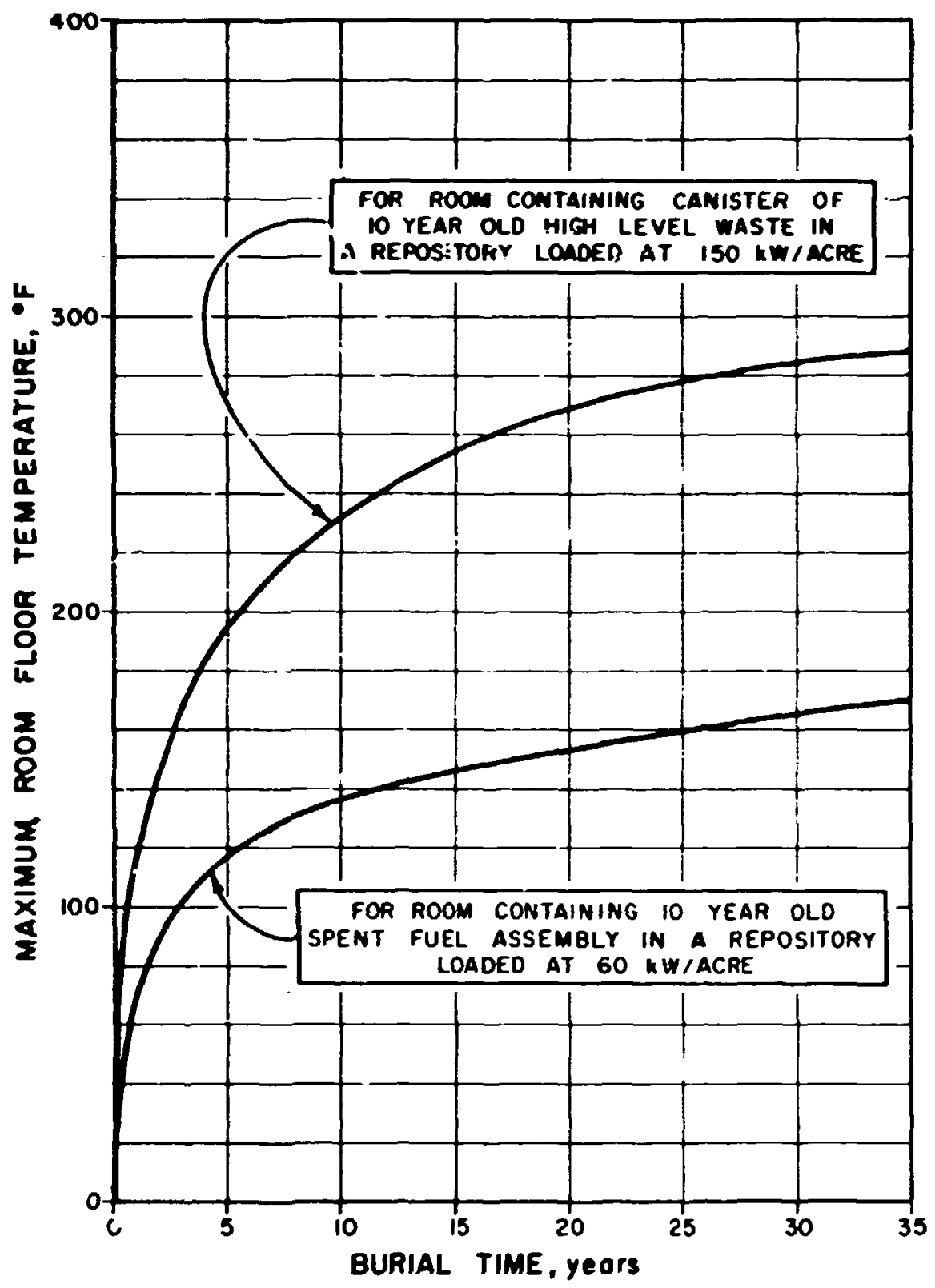

Fig. 8.17. Comparison of maximum temperature on the floor of the stnrage room as functions of time due to SF stored at $60 \mathrm{~kW} / \mathrm{acre}$ and $\mathrm{HLW}$ stored at $150 \mathrm{~kW} /$ acre.

pertinent times in planes orthogonal to the coordinate axis passing through the center of the heat source. F1gure 8.18 shows the 1sotherms in the $X Z$ plane from case 5 for SF fust prior to the scheduled backf111ing, 25 years after burial. Appreclable gradients in the 1sotherms were observed in this plane close to the source. Figure 8.19 shows the temperature increases that occur at the horlzontal midplane between canisters in a nonbackfilled 


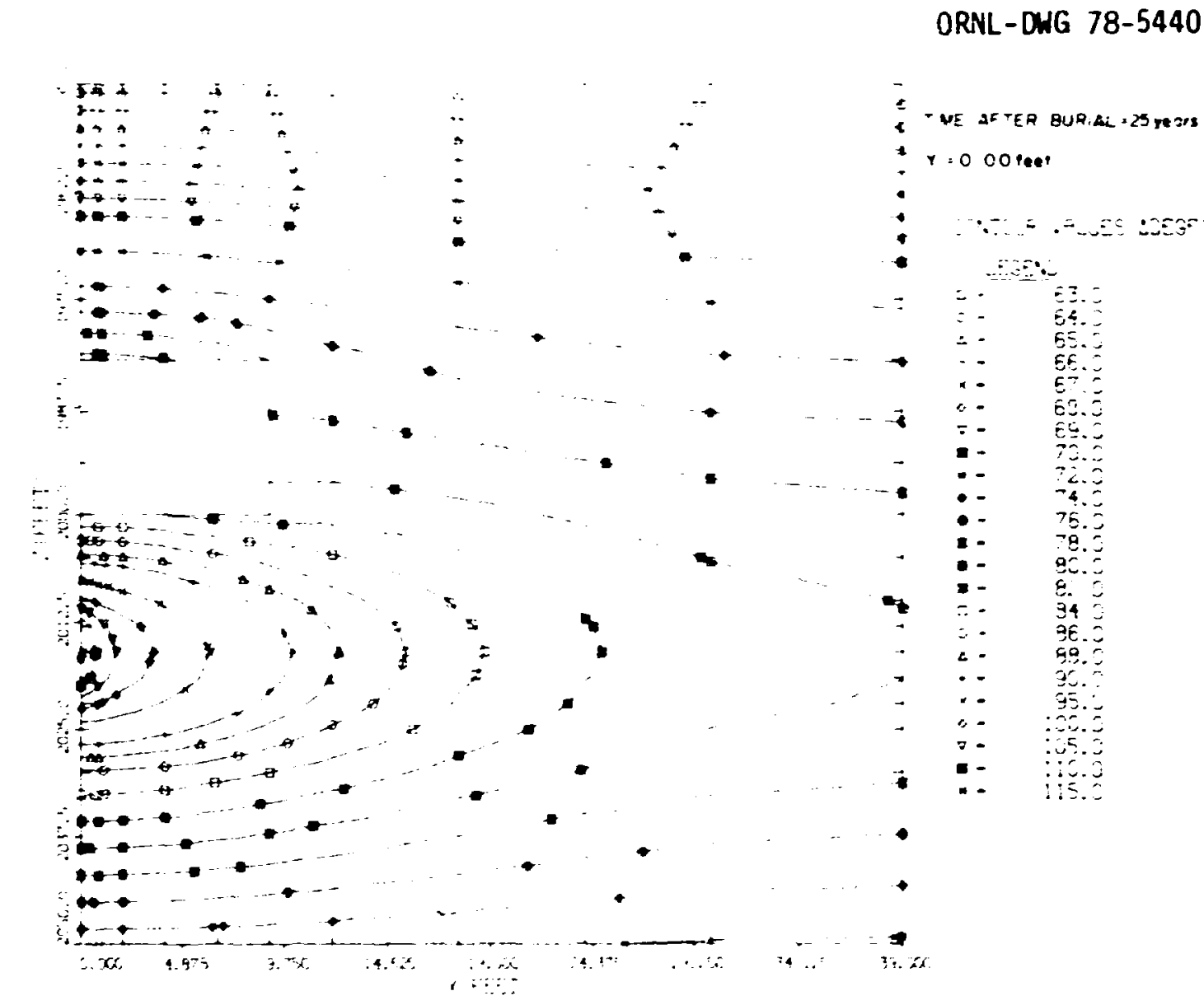

Fig. 8.18. Contours for temperature ircreases in the $X Z$ plane 25 years after burial in the three-dimensional unic-cell model for SF stored at $60 \mathrm{~kW} / \mathrm{acre}$.

room 25 years after burial. Notice that $\Delta T$ variations up to $14^{\circ} \mathrm{F}$ are found in the midplane between the canisters that are spaced $5.12 \mathrm{ft}$ apart along the same room, whereas as much as $35^{\circ} \mathrm{F} \Delta \mathrm{I}$ variations were noted between the canisters that are spaced in adjacent rooms $78 \mathrm{ft}$ apart.

Similar isotherms have been generated from case 6 for HLi. Figure 8.20 shows the isotherms in the $X Z$ plane from case 6 for HLW just prior to scheduled backfilling, 5 years after burial. Figure 8.21 shows isotherms at the midplane, which emphasizes again that the variations in ITs occur$r$ ing between canisters can be as much as $155^{\circ} \mathrm{F}$. 


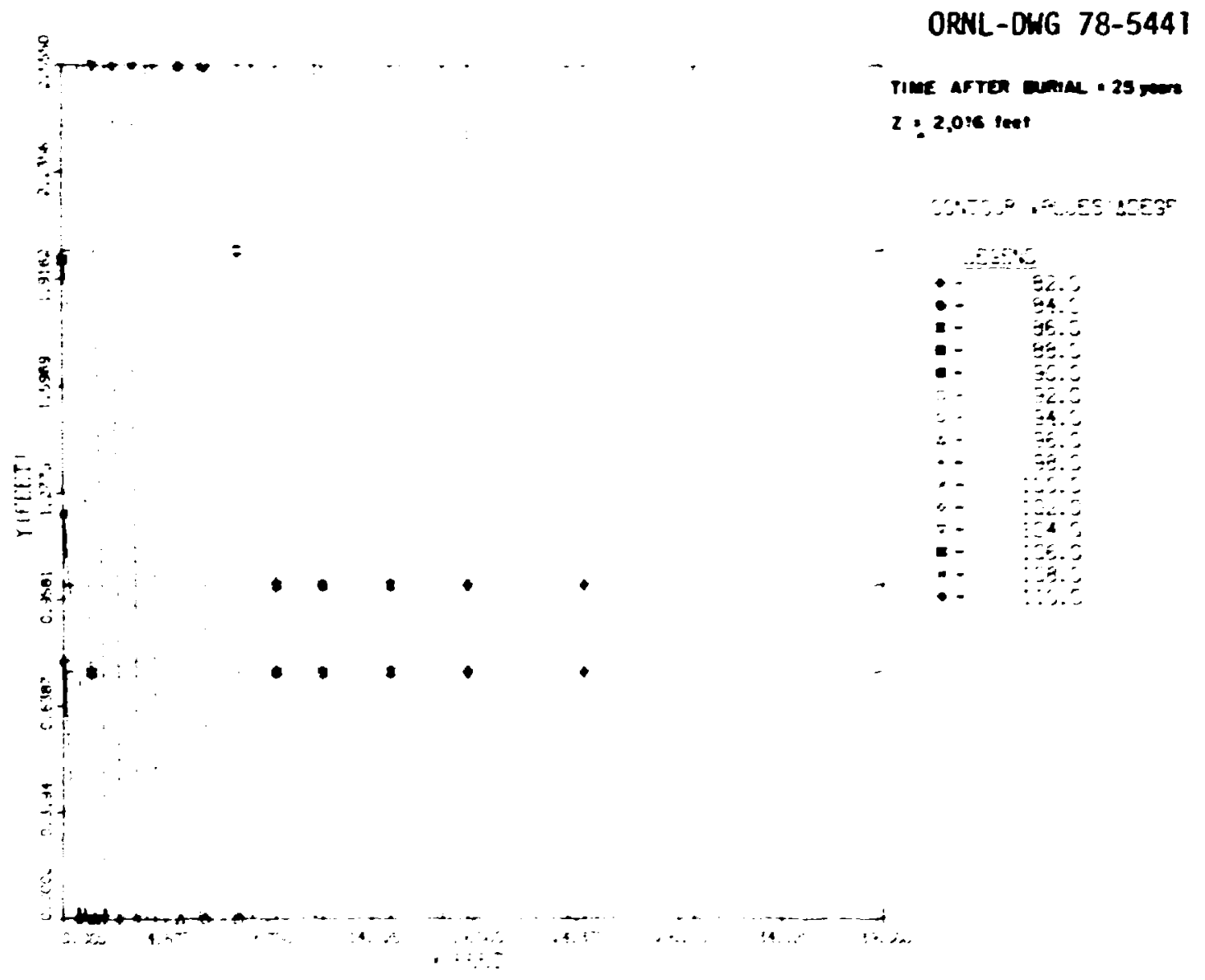

Fig. 8.19. Contours for temperature increases in the horizontal midplane 25 years after burial in the three-dimensional unit-cell model for SF stored at $60 \mathrm{kH} / \mathrm{acre}$.

\subsection{Multiple Row Far-Field Model of a High-Level Repository (Case 7) and Numerical Results}

The unit-cell models previously described and analyzed have provided a means of calculating conservative maximum temperature increases in the storage media for the terminal and retrievable storage of SF and HLW.

General temperature increases remote from the source are obtained from the far-field models. The actual temperature distribution in the repository will consequently lie somewhere in between and can be predicted only by a complete simulation of the entire repository, which would include both the near-fleld and far-field effects. Such a model would be very complex, include millions of nodes, and require excessive computer time and storage. 


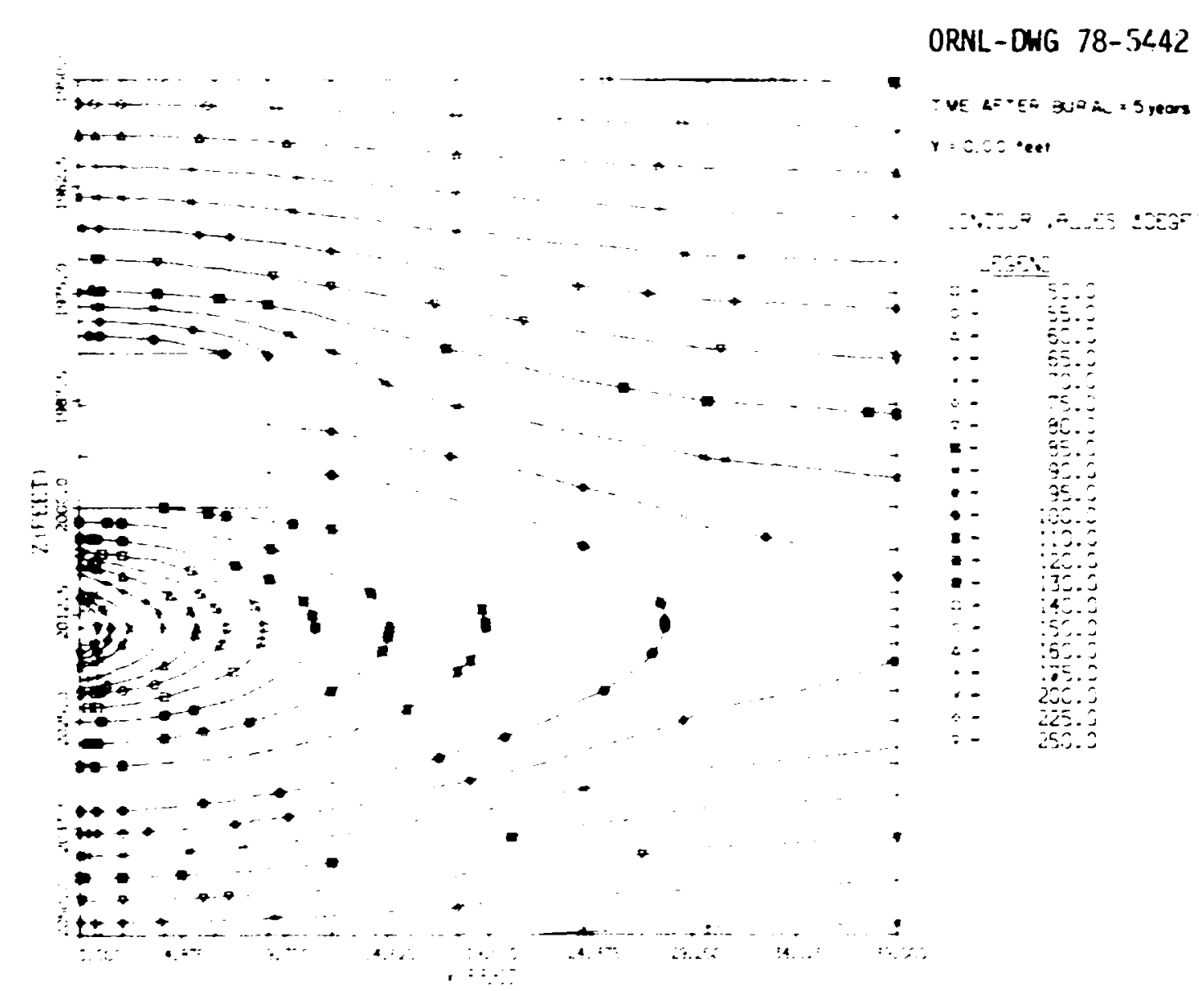

Fig. 8.20. Contours for temperature increases in the $X Z$ plane 5 years after burial in the three-dimensional unit-cell model for HLW stored at $150 \mathrm{~kW} /$ acre.

As a supportive far-field model, a multiple row, partially homozenized model has been developed which does not simllate each unit cell (canister) by itself but partially takes its effect iitu account by using multiple rows of infinite slabs in a two-dimensional model. By comparing the twodimension: 1 far-field homogenized model with the multiple row model, we were able to establish credible temperature limits produced by the farfield horogenized model.

A section through a repository assumed to contain canisters of HLW loaded on infinitely long $1-\mathrm{ft}$-wide rows spaced $78 \mathrm{ft}$ apart is shown in Fig. 8.22. This configuration models an HLW repository with an initial heat production rate of $150 \mathrm{~kW} /$ acre from a depth of 2010 to $2018 \mathrm{ft}$, as specified in the conceptual repository design. The homogenized heat 
ORNL-DWG 78-5443

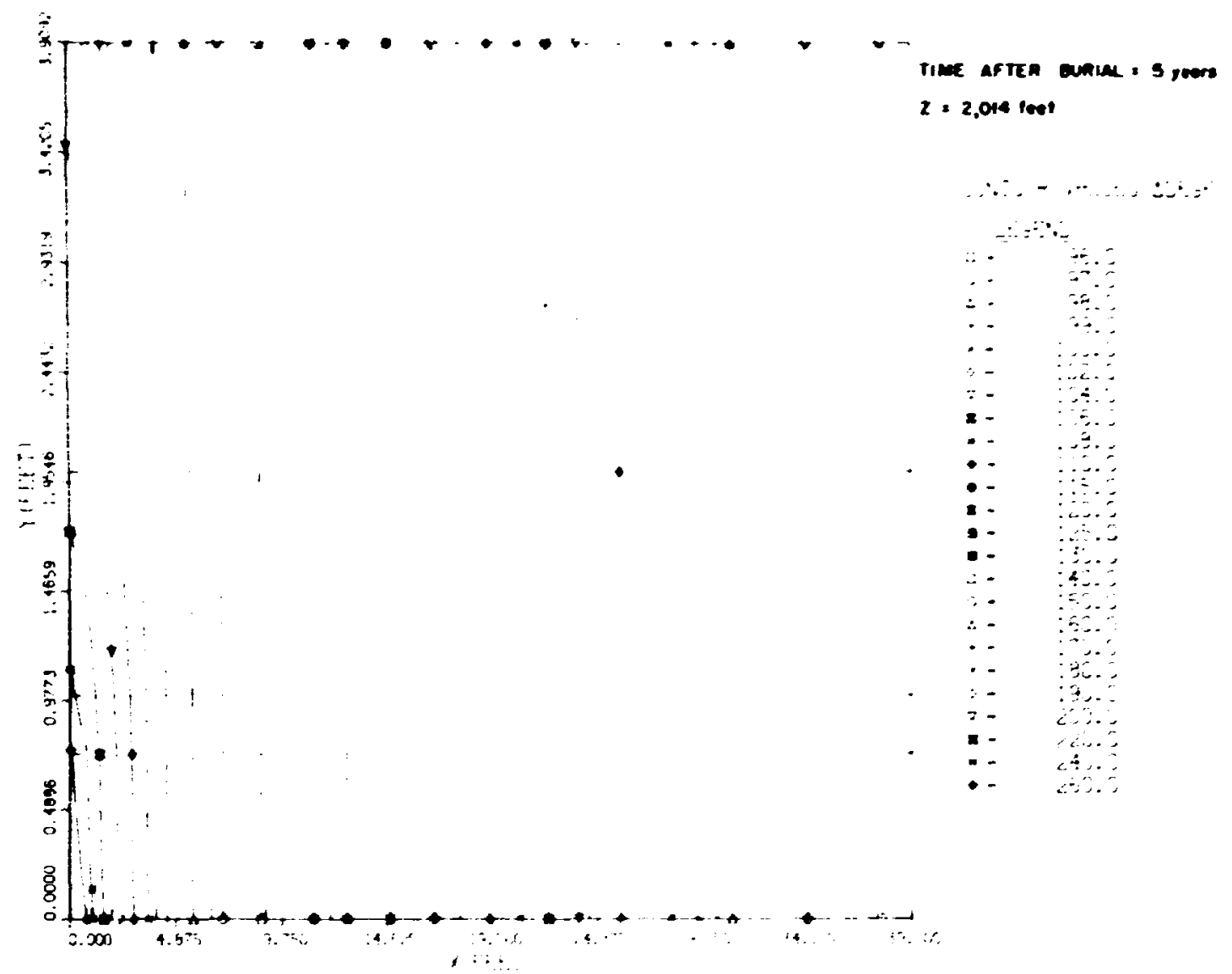

Hig. 8.21. Contours for temperature increases in the horizontal midplane 5 years after burlal in the three-dimensional unit-cell mocel for $\mathrm{HLW}$ stored at $150 \mathrm{~kW} / \mathrm{acre}$.

generation in each infinite slab is based on $2.1 \mathrm{~kW}$ being uniformaly distributed in a slab volume that is $1 \mathrm{ft}$ thick, $8 \mathrm{ft} \mathrm{high,} \mathrm{and} 7.82 \mathrm{ft}$ deep (which is the pitch of the canister emplacement), which yields a volume of $62.55 \mathrm{ft}^{3}$ and an initial heat generaition rate of $1.0 \times 10^{6}$ $\mathrm{Btu} / \mathrm{yr} \cdot \mathrm{ft}^{3}$. The actual $\mathrm{HLW}$ heat source is about 280 times the strength of the homogenized source used in the two-dimensional, completely homogenized far-field model but only about 3-1/2. times as strorg as the partially homogenized source used in the multiple row model.

The modeled reposicory c.:tends from the center of the repository to $3510 \mathrm{ft}$, which is $39 \mathrm{ft}$ past the centerline of the last row of canisters. The axial 1imits of the model are confined from 880 to $4000 \mathrm{ft}$, and the $X$ direction extends to $4000 \mathrm{ft}$, which is adequate for the time span 


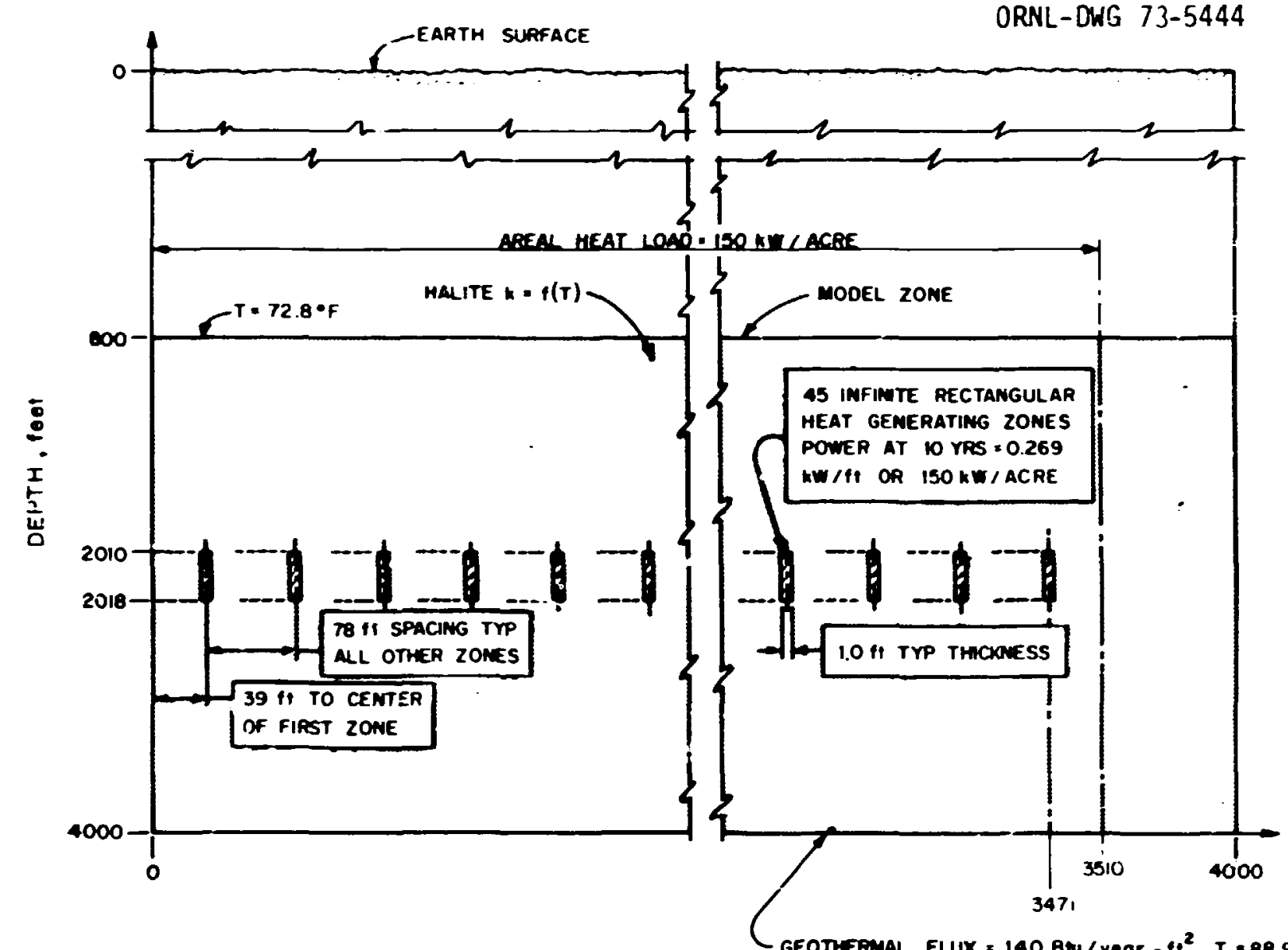

ORNL-DWG 73-5444

HORIZONTAL DISTANCE IN REPOSITORY, feet

Fig. 8.22. Section through multiple row model showing repository from the center to the edge.

involved. Nodes were selected to obtain temperature distribution between the rows of slabs as well as on their centers. A geothermal flux of $140 \mathrm{Btu} / \mathrm{yr} \cdot \mathrm{ft}^{2}$ was imposed on the lower axial boundary. An initial linear temperature distribition is assumed to range from $72.8^{\circ} \mathrm{F}$ at $800 \mathrm{ft}$ to $88.9^{\circ} \mathrm{F}$ at a depth of $4000 \mathrm{ft}$. The HEATING5A computer program was used to analyze this model.

Ffgure 8.23 shows the temperature increases at the edge of the repository as functions of the horizontal distance from the center of the repository at various elevations 27 years after burial, the time at which the peak $\Delta T$ of this andel is reached.

Notice that all of the "peaks" and "valleys" in the $\Delta T$ s remain fairly constant as a function of horizontal position throughout the repository. 
ORNL-DWG 78-5452

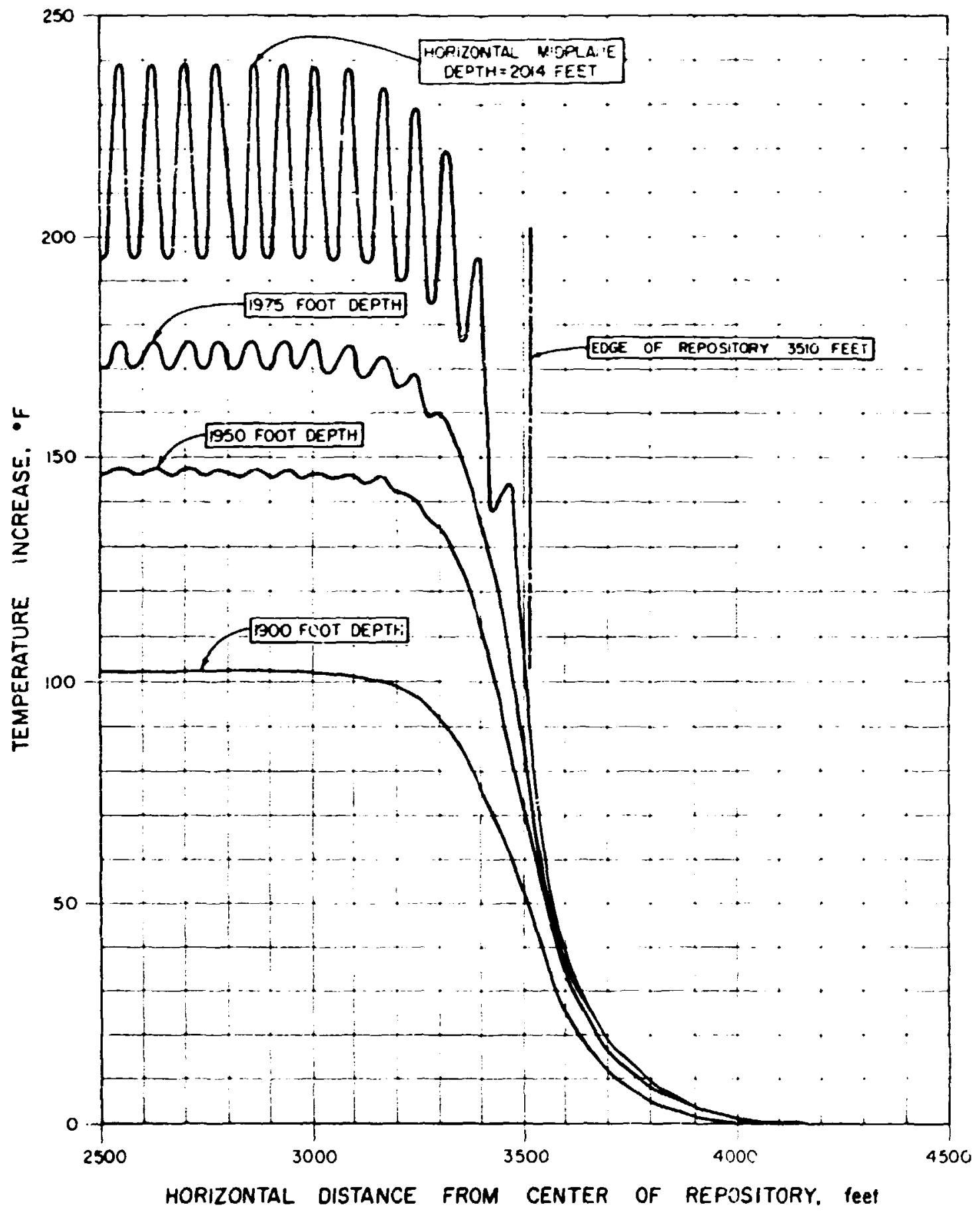

F1g. 8.23. Temperature increases at various depths in the salt repository as a function of horizontal position. 
At the horizontal aidplane the peak $\triangle I$ is about $239^{\circ} \mathrm{F}$ whereas the $2 T$ in the valley is about $195^{\circ} \mathrm{F}$, which indicates temperature variations as much as $44^{\circ} \mathrm{F}$ between the roous. This temperature differential is actually a function of time and was found to be as much as $62^{\circ} \mathrm{F} 1$ year after burial, diminishing to as little as $7^{\circ} \mathrm{F} 100$ years after burial. The three-dimensional model predicted variations of $170^{\circ} \mathrm{F} 1$ year after burial, diminishing to $121^{\circ} \mathrm{F} 20$ years after burial. The difference is due to the partial heat source homogenization taking place in the multiple row model.

Figure 3.23 also shows the periurbations (peaks and valleys) in temperature increases at elevaticns more remote from the source. It is important to note that the perturbations have almost subsided at a depth of $1950 \mathrm{ft}$ and have completely subsided at a depth of $1900 \mathrm{ft}$. The effect. of the cemperature perturbations in the radial direction is also confined to within about $100 \mathrm{ft}$ of the edge of the repository.

This observation can serve as an indication that the two-dimensional completely homogenized model is a valid and representative model for zones beyond about $100 \mathrm{ft}$ both horizontally and verticaily away from the repository. The multiple row model also gives a better representation of the temperature distribution around the edge of the repository. The peak $\Delta T s$ obtained from the analysis of the mulsiple row model should not be construed as realistic local maximum $\Delta T$ s since they are the results of homogenized heat sources; the unit-cell medels are to be used for this purpose. 


\section{COMPARISON OF RESULTS FROM HLW MODELS}

In oider to ascertain the range of validity of the various nodels, It was necessary to make comparisors of maximum temperature increases $(\Delta T s)$ as functions of both time and position for the models. To simplify the effort, these comparisons are limited to $\mathrm{HLW}$ stored at $150 \mathrm{~kW} / \mathrm{acre}$ and $2.1 \mathrm{~kW} /$ canister. Five models are considered in this comparison and include one-dimensional and two-dimensional homogenized far-field models, a twodimensional partially homogenized model, and both tio - and three-dimensional unit-cell models. These models have been described and analyzed in previous sections, but the models and the results have not yet been compares.

The time required for the temperatures or the temperature increase:s $(\Delta T 3)$ tr peak varies from model to model. The earliast peaking tine encountered is in the throe-dimensional model, which peaks 20 years after burial; the two-dimensional unit-cell model peaks after 25 years. The two-dimensional muitiple row far-field wodel peaks in 27 years, and the one-dimensional and two-dimensional far-field homgenized mojels peak last - both in 35 years. These differences are due to concentration oi the heat source, the location of the adiabatic boundaries, and the heal capacitance of the model.

Comparisons of $\Delta T s$ obtained for HLW from the various models as functions of time and position will be made in the followirib sections.

\subsection{Temperature Differences as Functions of Time}

Increases in the nidplane salt temperature ( $\Delta \mathrm{Ts}$ ) from 125 to $301^{\circ} \mathrm{F}$ were obtained fr the various models showr in Fig. 9.1. This plot shows how the maximum salt $\Delta$ rs located on the horizontal mioplane vary with time. The differences notad over the complete range of all of the models is really not significant because the unit-cell and far-field models are intended for two entirely dirferent purposes. The unft-cell results are for local maximum representation, whereas the far-fleld models are for average repository representation. These comparisons are necessary, howevar, to convey to the reader some idea of the divergence of the model types. 
ORNL-DWG $78-5445$

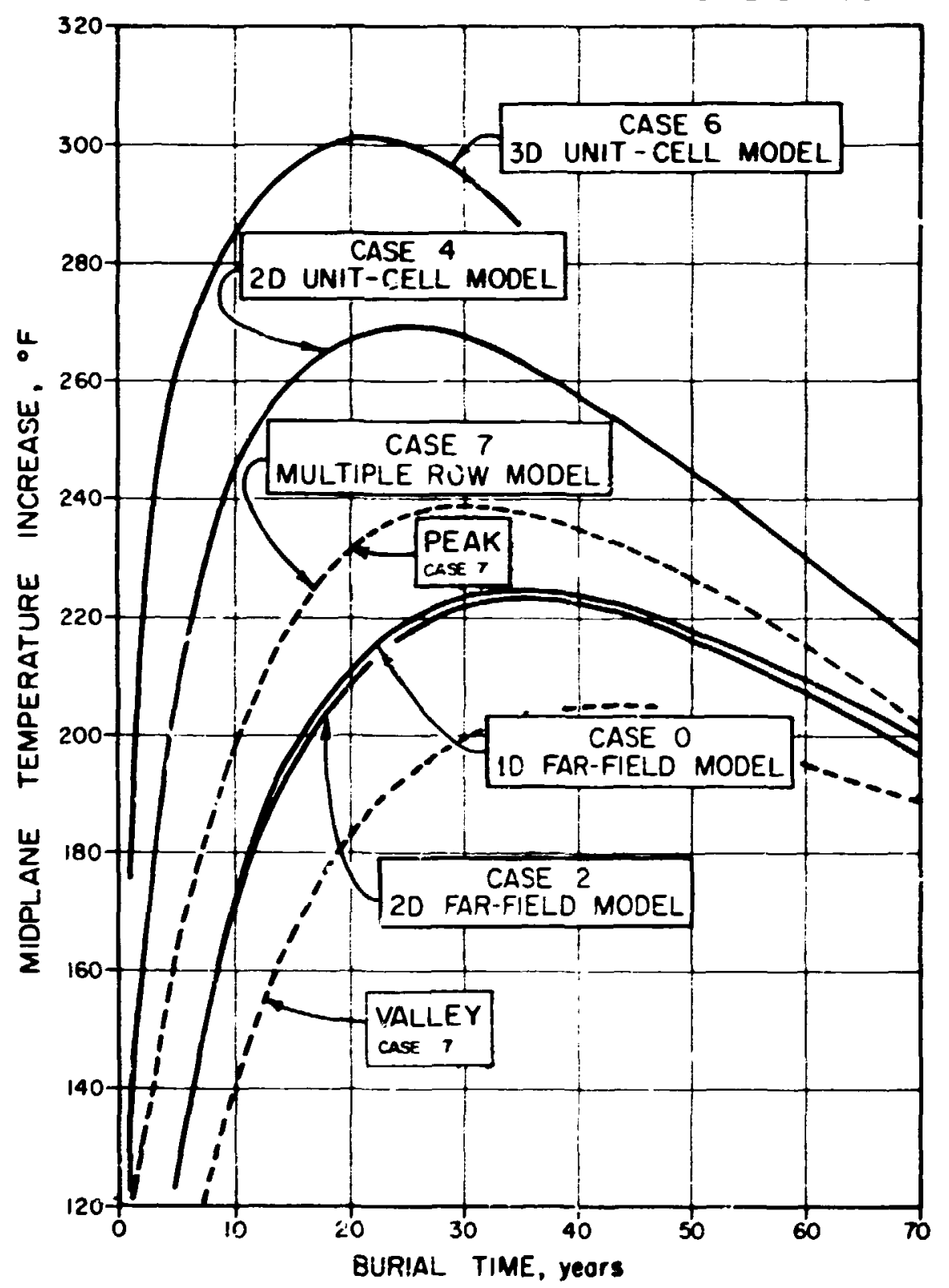

Fig. 9.1. Compartson of temperature increases from various models of a HLW repository as function: nf time.

A diffe ence of $32^{\circ} \mathrm{F}$ or $35 \%$ was noted in the $\Delta \mathrm{Ts}$ obtained in the unitcell models. The marked difference in the unit-cell modeis is due to difference in the geometrical configuration of the areas of the two models, the location of the adlabatj.c boundaries, and the fact that the threedimens'onal model has an alr-filled room, whereas the two-dimensional model 
does not consider the room. If the alr-filled room in the three-dimensional model were filled with solid salt, the maxinum $\Delta T$ obtained from both the two-dimensional and three-dimensional unt:-cell models would probably be much closer, although differences should still be noted in their distribution because of the difference in geometrical configurations.

The maximum $\Delta \mathrm{T}$ of $260^{\circ} \mathrm{F}$ obtained in the salt at the time of backfillIng - 5 years after burial - should be the main point of interest for the HLW repository having the assumed stratigraphy and loading used in this study because temperatures aeveloped after backf 1111 ing are not of much concern to the designer. The three-dimensional unit-cell model seems to be not only more conservative but also simulates the actual situation quite accurately over most of the repository area. This conclusion is based on the observation from both :he two-dimensional homogentzed and two-dimenslonal multiple row far-field models that (1) not much heat flow interchange is taking place between the cani.:ters throughout most af the repository (F1gs. 8.6, 8.7, and 8.12 ) and (2j the three-dimenstonal unitcell model exerts the same characteristics of temperature variationa between cantsters as are also obierved in the peaks and valleys of the multiple row model (F1g. 8.23).

In comparing the far-fieid models, it must be emphasized tinat the $\Delta$ Ts shown in Fig. 9.1 do not represent anj one point in. space but rather temperature increase, which, as indicated before, was found to be fairly uniform throughout most of the repository. In this comparison, it is interesting to note that the peak $\Delta T s$ obtained from the one-dimensional and two-dimensional far-field fodels are in very close agreement. If maximum axial temperature distributions were the only results desired, it would probably be quite satisfactory (at least to within several hundred feet of the source) to use one-dimensional models in making parameter studies. This offers tha possibility of quite a saving since the CPU time 1s only about $4 \%$ of that required in the analysis of the two-dimensional homogenized model.

The peaks and valleys of the multiple row model show the temperature fluctuatjons expected between the rows of canisters, and the average is in agreement with the one-dimensional and two-dimensional homogenized farfield models. These fluctuations are not as steep as those observed in 
the three-dimensional unit-cell model because of the partial homogenization of the heat source along each row. The three-dimensional unit-cell results are much more realistic in this respect.

Comparisons of midplane $\Delta T$ s obtained at the edge of the HLW repository from two-dimensional far-field models are shown in Fig. 9.2. A peak $\Delta T$ of $148^{\circ} \mathrm{F}$ is produced on the horizontal midplane on the outer row of the repository in the multiple row far-field model 20 years after burial at a distance of $3471 \mathrm{ft}$ from the center of the repository or about $39 \mathrm{ft}$ inside from the edge. This peak on the outer row is reached 7 years before the peak is reached in the center of the repository. A peak $\Delta T$ of $89^{\circ} \mathrm{F} 18$ found at the edge of the repository $3510 \mathrm{ft}$ from the center of the multiple row model. This peak is reached 35 years after burial. A peak $\Delta T$ of $102^{\circ} F$ is observed at the edge of the repository $3500 \mathrm{ft}$ from the center of the hor sontal midplane in the two-dimensional homogenized far-field model; this peak is also reached 35 years after burial. It is apparent from these observations that peripheral repository $\Delta T s$ on the horizontal mijplane require 35 years or more to peak depending on their proximity to the repository, wherzas about 20 years are required fiside of the reposttory. The peak $\Delta T$ s calculated on the edge of the repository are about $15 \%$ greater for the homogenized model than for the partially homogenized multiple row model because heat generation in the homogentzed model 18 extended all the way to the edge. At istances of $100 \mathrm{ft}$ c- wor. from the edge of the repository along the horizontal midplane, the $\Delta T s$ from both far-field models are about the same.

It appears that the two-dimensional homogenized far-field model is conservative on the edge and becomes valid at distances of $100 \mathrm{ft}$ or greater from the repository zone.

The peak repository midplane temperature increases expected from the far-field analysis are shown in Fig. 9.3 as functions of areal power for both SF and HLW. These are approximate values taken from the models analyzed in this study (as indicated) and from the results presented in ref. 1. The height referred to in the figure is the height of the homogenized heat generation zone in the two-dimensional far-fleld model based on the active height of the hear. production in the canister. 
ORNL-DWG $78-5446$

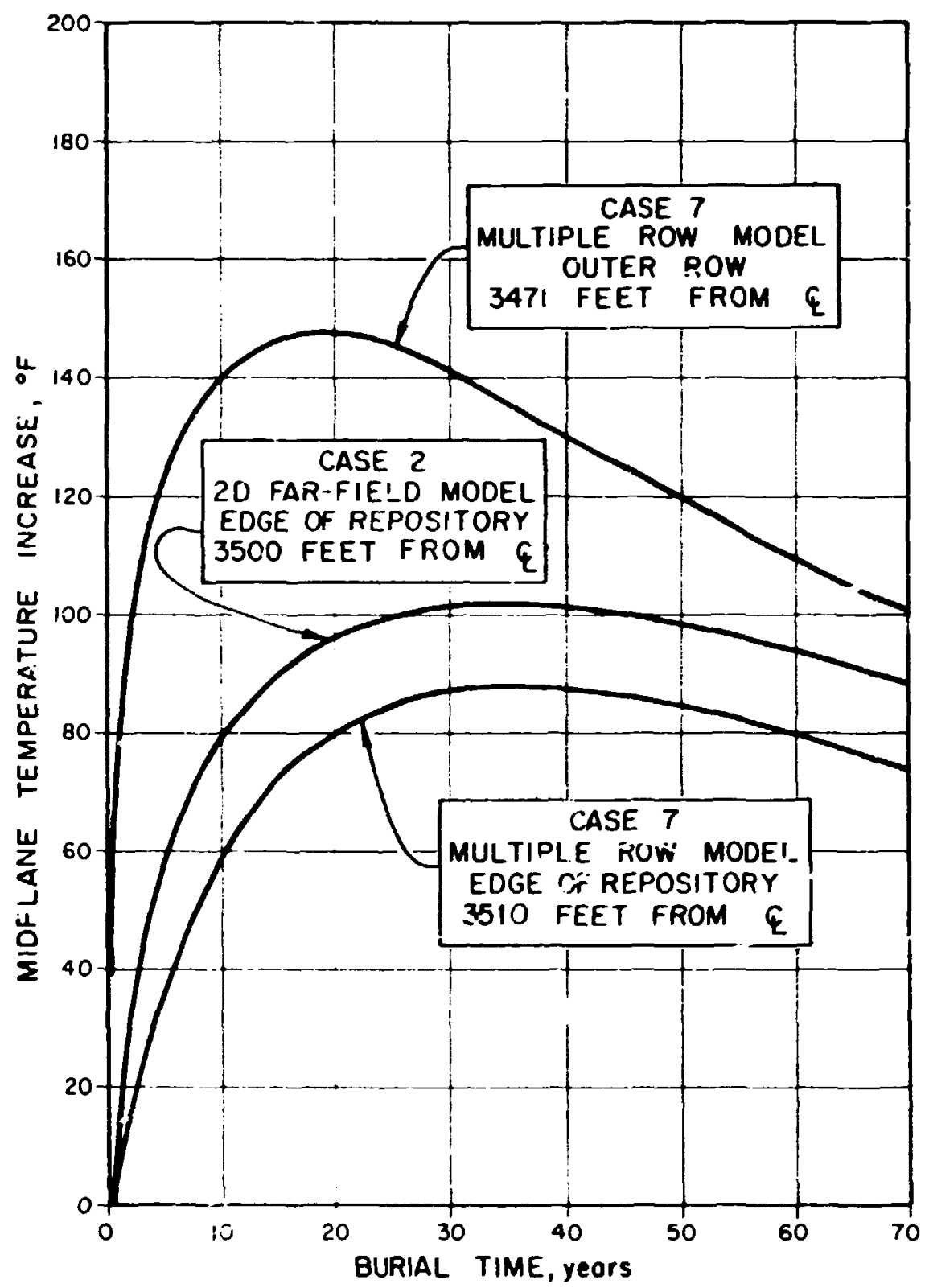

Fig. 9.2. Comparjson of midplane temperature increases on outer edge of repository obtained from two-dimensional far-field models storing dLW at $150 \mathrm{~kW} /$ acre as functions of time.

9.2 Peak Temperature Increaseg as Functions of Depth Below the Surface of the Earth

Peak $\Delta T$ s as functions of depth below the surface of the earth are shown in Fig. 9.4 for various far-field models at the time the peaking in each model occurs. Notice that within the 100-ft distance above and below 
ORNL-DWG 78-5447

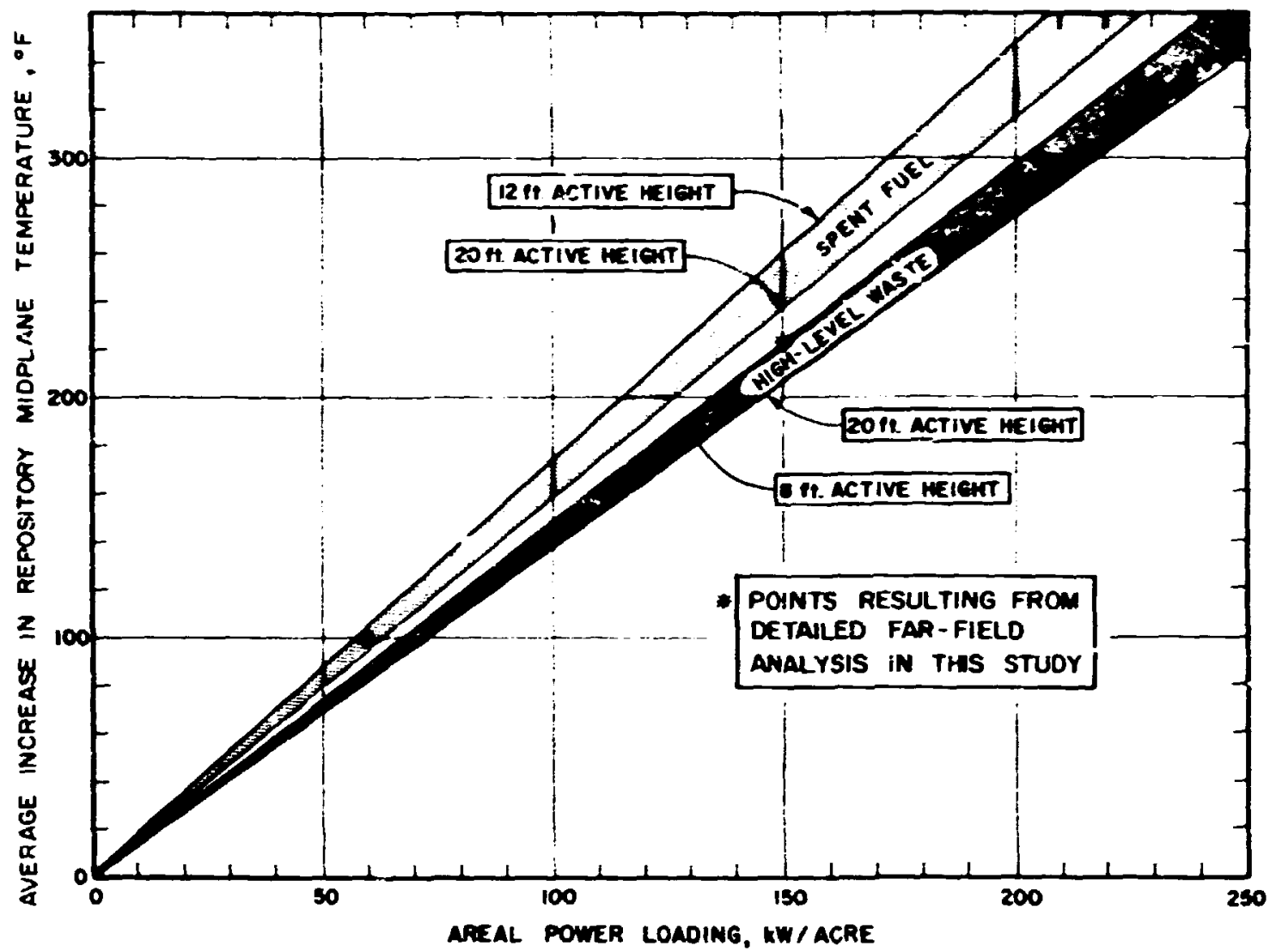

Fi8. 9.3. Midplane temperature increases in far-field models produced by $S F$ and $H L W$ as a function of areal heat load.

the midplane, the differences between peaks and visleys in the partially homogenized multiple row mojel are apizrent, but when averaged, the $\Delta T$ s are in close agreement with the completely homogenized two-dimensional model. Beyond the 100-ft distance, the perturbations subside completely, and the homogenized models an be considered as reilistic representation of the temperatures expected.

Figure 9.5 shiuws the comparison of peak $\Delta T$ s obtained from two-dimensional and three-dimensional unit-cell models as functions of depth below the earth's surface. As prcviousl: inentioned, the three-dimensional model assumes a rectangular nonbackfilled room, which reduces the heat capacitance and conductance of the three-dimesnional model and places the heat source much closer to the adiabatic bourdary. These conditions contribute to the earlfer peaking at the central location on the horizontal midplane 
ORNL-DNG 78-5454

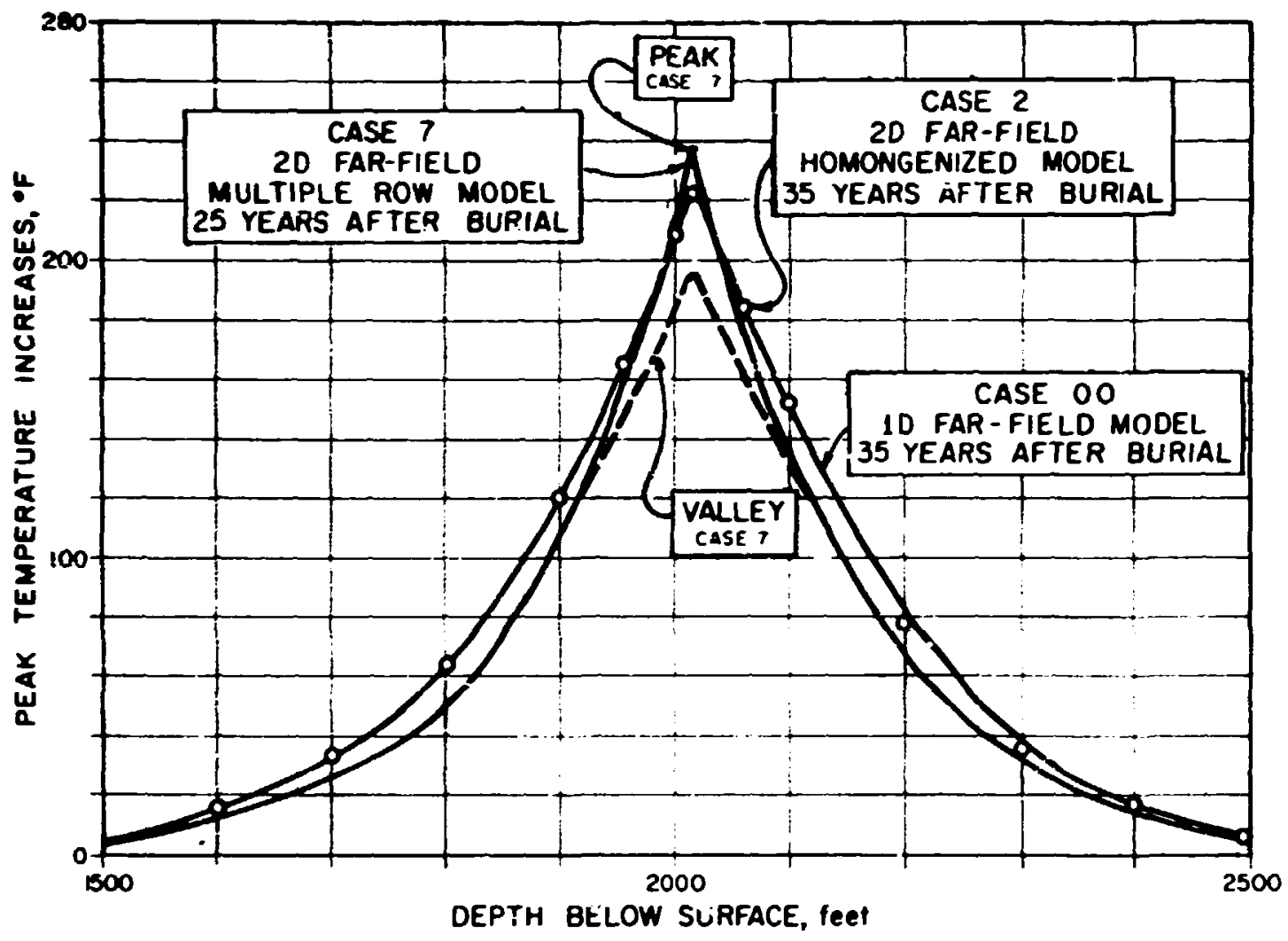

Fig. 9.4. Comparison of peak temperature increases obtained from varlous far-field modeis for storing HLW as functions of depth below the surface of the carth.

In the three-dimensional model as compared with the two-dimenstonal model. The sealed alr-filled room also adds resistance to heat flow and increases the peak maximum $\Delta T$ in the salt. 


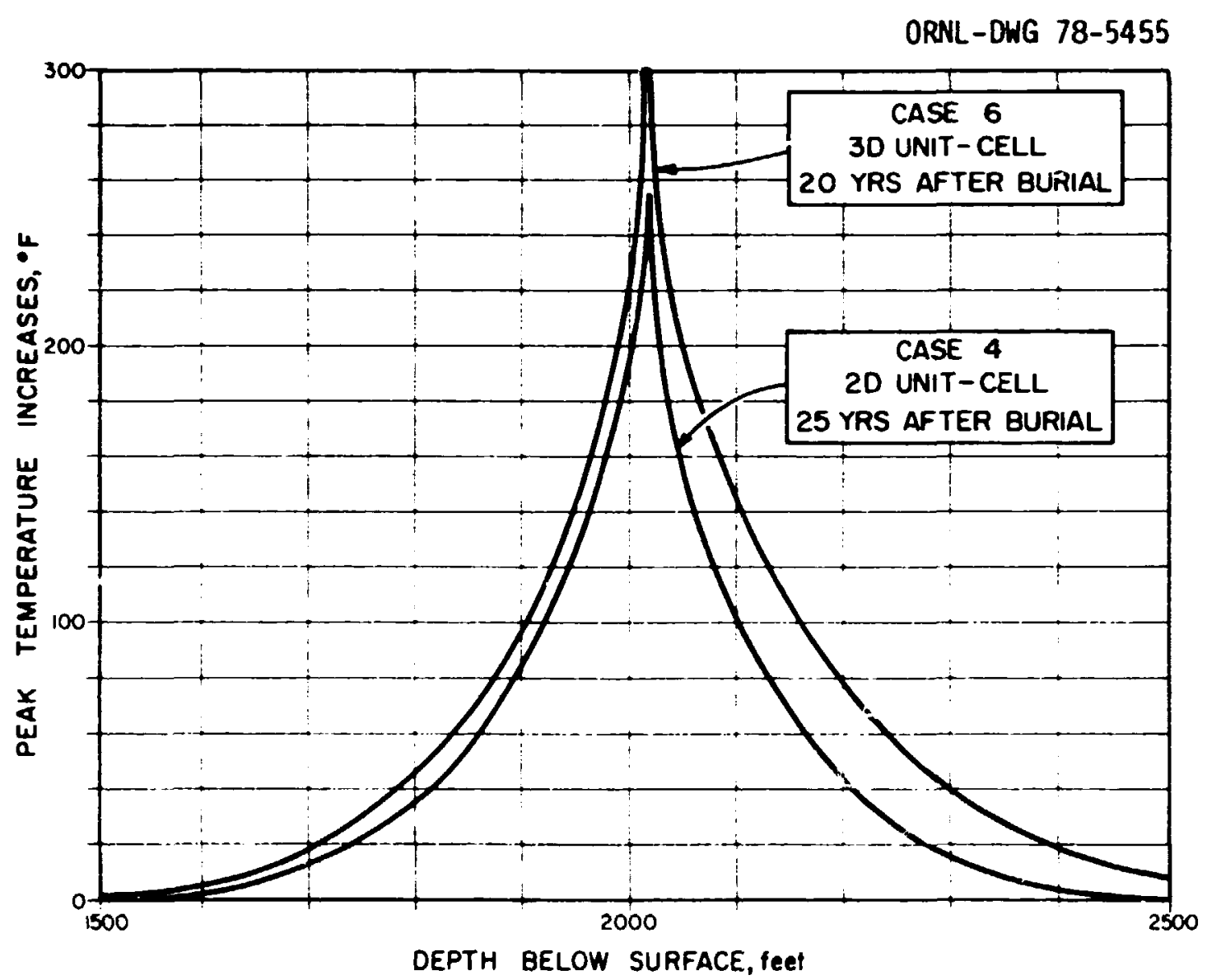

Fig. 9.5. Comparison of peak temperature increases from two- and three-dimensional unit-cell modeis as functions of depth below the surface of the earth, incurred in the storage of $\mathrm{HLW}$ at $150 \mathrm{~kW} / \mathrm{acre}$. 


\section{RESULTS AND CONCLUSIONS}

A study has been made of the temperature distribution that results within and outside a repository storing either SF or HLW. First, preliminary simulations of far-field and unit-cell configurations have been made for both cases with an areal heat load of $150 \mathrm{~kW} / \mathrm{acre}$. The main conclusion from this part of the analysis is that, for the same areal power distribution ( $150 \mathrm{~kW}$ /acre), the maximus temperature increase for SF is about $19 \%$ higher than for HLW based on far-field analysis and $12 \%$ based on unit-cell analysis.

From thermoelastic analysis, it was found that a comparable upheaval of the earth is expected from storing either SF with areal power distribution of $60 \mathrm{~kW} /$ acre or HLW with areal power distribution of $150 \mathrm{~kW} / \mathrm{acre}$. Far-field and unit-cell analyses have been performed for those cases with the following results and conclusions.

1. The maximum $i T$ expected in an open repository containing 10-yearold HLW stored at $150 \mathrm{~kW} /$ acre and $2.1 \mathrm{~kW} /$ canister under the assumption outlined in this report is about $260^{\circ} \mathrm{F}$, which results in a maximum temperature of about $339^{\circ} \mathrm{F}$ occurring prior to backfilling ( 5 years after burial). The anticipated maximum temperature rise in the flor 5 years after burial in a sealed, but not backfilled, room is about $210^{\circ} \mathrm{F}$, which results in accessible temperatures of about $289^{\circ} \mathrm{F}$.

2. The maximum $\Delta T$ expected in an open repository containing SF stored $60 \mathrm{~kW} /$ canister prior to backfilling ( 25 years after burfal) is about $105^{\circ} \mathrm{F}$, which results in a maximum temperature of $184^{\circ} \mathrm{F}$. In the case of the $\mathrm{SF}$, the peak $\Delta T$ on the floor of the room prior to backf $\$ 11$ ing (25 years after burial) is about $82^{\circ} \mathrm{F}$, producing accessible temperatures of about $161^{\circ} \mathrm{F}$.

3. Ground surface $\Delta T$ s of no more than $0.01^{\circ} \mathrm{F}$ are expected directly over a repository initially containing $133 \mathrm{MW}$ of either SF or HLW buried in a salt repository at a depth of $2000 \mathrm{ft}$.

4. The HLW produces a maximum peak $\Delta T$ about three times that of the SF but requires on 1 y $40 \%$ of the storage area and $25 \%$ of the number of canisters, but the anticipated thermal uplift is about the same. After about 300 years, the peak $\Delta T$ s in the SF exceed those in the HLW. 
The following conclusions were made after comparing the results of the various models.

1. The far-iield models have shown that radial heat flow within the repository is neglizible, which reinforces the assumption of adiabatic boundary conditions on the unit-cell models over most of the repository area.

2. The $\Delta$ Ts produced by the homogenized far-field models are valid at distances greater than $100 \mathrm{ft}$ from the homogenized heat source based on comparisons made with the multiple row model, which more accurately simulates the eige of the repository.

3. There is an appreciable variation in horizontal midplane temperatures between the canisters as noted from the three-dimensional unit-cel: model and substantiated by the multiple row far-field model.

4. The unit-cell models predict conservative peak maximum salt tenperature increase which are representative not only at the repository center but over about $80 \%$ of the total repository area.

5. The three far-field models yield results that support each other. The one-dimensional model is the least expensive and the most convenient to use when only temperature distribution versus depth is desired.

6. The three-dimensional unit-cell model seems to be conservative, but not overly sc. It simulates both the heat sources and the geometry in the most realistic way and supports the adiabatic boundary assumption that was substantiated with the far-field models for most of the repository area. This model seems to be most useful for both peak maximum temperature prediction as well as for estimating temperature variations between the canisters and in the open rooms. 


\section{References}

1. G. D. Callahan and J. L. Ratigan, Themoelastic Anaiysis of Spent Fuei Repositories in Bedded and Dome Sa?t, Y/OWL;SUB-77/22303/4, RE/SPEC, Inc., Rapid City, S.D., 1277.

2. R. D. Cheverton and W. D. Turner, Thermal Analysis of the National Fadioactive Waste Repository: Progress through March 1972, ORNL-4789, Oak Ridge National Laboratory, September 1972, p. 29.

3. C. W. Kee, A. G. Croff, and J. 0. Blomeke, Updated Projections of Radicactive wastes to be Generated by the U.S. Nuclear Power Industry, ORNL/TM-5427, Oak Ridge National Laboratory, December 1976, p. 30.

4. R. D. Cheverton and W. D. Turner, Thermal Analysis of the Nationat Radioactive Waste Repository: Progress through March 1972, ORNL-4789, Oak Ridge National Laboratory, September 1972, p. 54.

5. H. S. Carslaw and J. C. Jaeger, Conduction of Heat in Solids, Oxford University Press, 1959, Chap. 2.

6. L. R. Ingersol1, 0. J. Zobel, and A. C. Ingersoll, Heat Conduction With Engineering, Geological and Other Applications, University of Wisconsin Press, 1954, p. 143.

7. J. P. Nichols, Oak Ridge National Laboratory, persoral communication to G. H. Llewellyn, March 1971.

8. A. L. Edwards, TRUMP: A Computer Progran for Transient and SteadyState Temperature Distributions in Mut:idimensional Systems, revision 3, UCRL-14754, Lawrence Livermore Laboratory, Sept. 1, 1972.

9. R. G. Lawton, The AYFi Heat Conduction Computer Program, LA-1513-MS, Los Alamos Sctent1f 1c Laboratory, May 1974. 


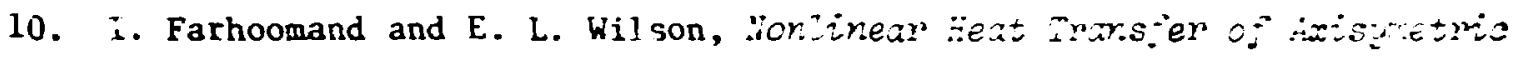
Solids, Structural Engineering Laboratory, University of California, Berkeley, Calif., Afril 1971.

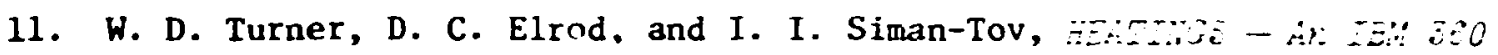
Heat Conduction Progran, ORNL/CSD/TM-15, Oak Ridge National Laboratory, March 1977.

12. B. C. Kaplan, D. B. Mizchell, and A. H. Mcore, "A Compazison of the Crandall and Crank-Nicholson Methods for Solving a Transient Heat Conduction Problem," Int. J. Nwmer. Methodi Erg. 9(4): 93\$-43 (1975).

13. R. D. Cheverton and W. D. Turner, Thermat Analisic of the rat iori Radioactive Waste Repository: Progress through dunz 1971, ORNL-4726, Oak Ridge National Laboratory, p. 4.

14. G. W. Giles, "HEATINGSA," letter to D. U. Turner, Dec. 5, 1977.

15. D. W. Turner and D. C. Elrod, let ter to R. H. Odegaarden. Office of Nuclear Material Safety and Safeguard, May 12, 1972.

16. C. W. Kee, A. G. Croff, and J. 0. Blomeke, Upiated Proiections o: Radioactive Wastes to be Generuted by the U.S. Nuclear Pcuer Industry, ORNL/TM-5427, Oak Ridge National Laboratory, December 1976, p. 33.

17. R. D. Cheverton and W. D. Turner, Thermal Analysis of the Irational Radioactive Waste Repository: Progress trirough March 1972, ORNL-4789, Oak Ridge Natiunal Laboratory, September 1972, p. 78.

18. M. J. Bell, ORIGEN - The ORNL Isotope Generation ard Detietion Code, ORNL-4628, Oak R1.dge National Laboratory, May 1973.

19. G. D. Smith et al., Soil-Temperature Regimes, Thein Characterictics and Predictability, SCS-Tp-144, USDA So11 Conservation Service, April 1964 .

20. T. Kusuda, National Bureau of Standards, U.S. Department of Commerce, Gatthersburg, Md., personal communication. 


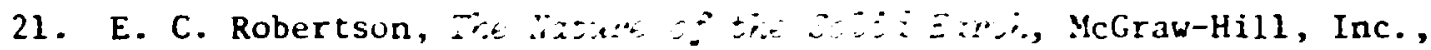
1972, Chap. 19.

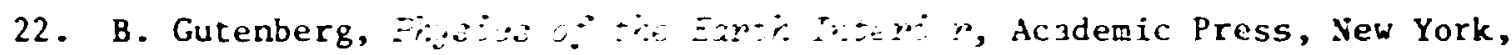
1959, p. 130.

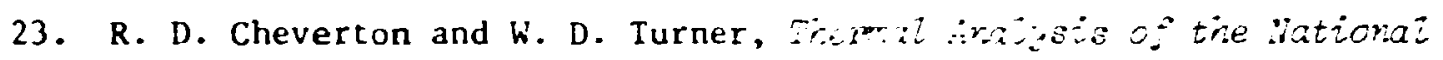

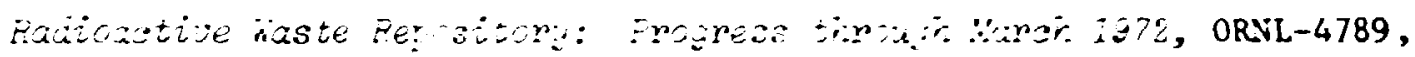
Oak Ridge National Laboratory, September 1972, pp. 33-34.

24. F. Birch and H. Clarke, "The Thermal Conductivity of Rocks and Its Dependence lipon Temperature and Composition," Part II, sim. e e. Sai, 238613-35 (1940).

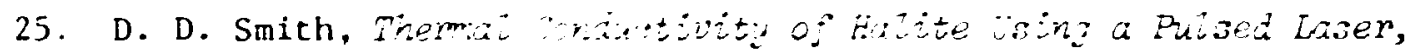
Y/DA-7013, Oak Ridge Y-12 Plant, Dec. 13, 1976.

26. B. Gutenberg, Fojo 1959 , p. 124.

27. A. M. Jessop, M. A. Hobart, and J. G. Srlater, The World Heat Flow Lata Cojediz - 1375 , Geothermal Service of Canada, Geothermal Series No. 5, Ottawa, Canada, 1976.

28. R. D. Cheverton and W. D. Turner, Themal Analysis o: the iational Radioactive Wasto Reporitor:: Progress trrougi Uroh 1072, ORVL-4789, Oak Ridge National Laboratory, September 1972, p. 1.

29. T. G. Godfrey, S. H. Jury, D. L. McElroy, Eaicastive haste he:osizny Project; Anmul Projess Re:ort, Period Enain, Sent. 30, 1972, ORNL-4824, Oak Ridge National Laboratory, p. 218.

30. D. C. Elrod and W. D. Turnex, HEATPLOT - A Temeratire Distribution

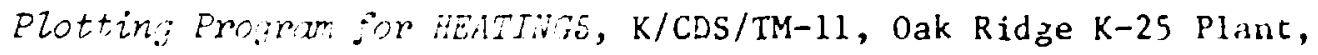
july 1977. 